\title{
Silicate-carbonate liquid immiscibility: insights from the Crevier alkaline intrusion (Quebec)
}

Groulier P.-A. ${ }^{1,2}$, Turlin F. ${ }^{1,2}$, André-Mayer A.S. ${ }^{1^{*}}$, Ohnenstetter D. ${ }^{3}$, Crépon A. ${ }^{1}$, Boulvais P. ${ }^{4}$, Poujol M. ${ }^{4}$, Rollion-Bard C. ${ }^{5}$, Zeh A. ${ }^{6}$, Moukhsil A. ${ }^{7}$, Solgadi F ${ }^{7}$, El Basbas A. ${ }^{7,8}$

${ }^{1}$ GeoRessouces laboratory, Université de Lorraine-CNRS, 54000 Nancy, France

${ }^{2}$ Now at Université du Québec à Montréal, Département des Sciences de la Terre et de l'Atmosphère, 201, ave. du Président-Kennedy, Montréal, QC, Canada H2X 3Y7

${ }^{3}$ CRPG, CNRS, Université de Lorraine, Vandœuvre-lès-Nancy, France

4 Univ rennes, CNRS, Géosciences Rennes - UMR 6118, F-35000 Rennes

5 Institut de Physique du Globe de Paris (IPGP), UMR CNRS 7154, Université Paris Diderot, 1 rue Jussieu, F-75238 Paris Cedex 05, France

${ }^{6}$ KIT-Karlsruhe Institute of Technology, Campus South, Institute for Applied Geosciences, Mineralogy and Petrology, 76131, Karlsruhe, Germany

${ }^{7}$ Ministère des Ressources Naturelles du Québec, Direction du Bureau de l'Exploration Géologique du Québec, 400, boulevard Lamaque, Val-d'Or (Québec) J9P 3L4

${ }^{8}$ Now at Faculté des Sciences Université Moulay Ismail BP: 11201 - Zitoune 50060 - Meknès, Maroc

*Corresponding author: anne-sylvie.andre@univ-lorraine.fr - +33 (0)3 72745566

ORCID Numbers:

Anne-Sylvie ANDRE-MAYER: 0000-0002-9307-1419

Pierre-Arthur GROULIER: 0000-0003-2386-9270

Marc POUJOL: 0000-0001-8682-2926

François TURLIN: 0000-0002-0378-6972

(C) The Author(s) 2020. Published by Oxford University Press. All rights reserved. For Permissions, please e-mail: journals.permissions@oup.com 


\section{Abstract}

This contribution explores the petrogenetic relationships between silicate and carbonatitic rocks in the Crevier Alkaline Intrusion (CAI, Québec, Canada). The CAI is located in the Proterozoic Grenville Province and is composed of a suite of undersaturated peralkaline rocks from ijolite to nepheline syenite and carbonatites. Petrogenetic relationships between different undersaturated alkaline igneous rocks, carbonate-bearing and carbonate-free nepheline syenite and carbonatites observed in the CAI suggest that (i) carbonate-bearing and carbonate-free silicate rocks are comagmatic with carbonatite, and that (ii) both silicate and carbonatitic liquids are fractionated from an ijolitic parental magma that has undergone liquid immiscibility. One of the observed facies is characterized by spectacular ocelli of carbonate-bearing nepheline syenite in a matrix of carbonatite. The younger nepheline syenite facies can be divided into two groups based on the presence or absence of magmatic carbonates. Both groups are characterized by the presence of pyrochlore-group minerals that carry the $\mathrm{Nb}$-Ta mineralization.

We specifically use accessory minerals such as zircon, pyrochlore and apatite to constrain the temporal and physicochemical parameters of the immiscibility process. By coupling (i) mineral textures, (ii) trace elements, (iii) Ti-in-zircon thermometry, and (iv) oxygen isotope compositions, we have traced the crystallization of zircon before, during and after the immiscibility process. The results allowed us to constrain the minimum temperature of this process at $\sim 815-865^{\circ} \mathrm{C}$. In addition, two magmatic populations of pyrochlore are identified through their petrographic and geochemical characteristics within the younger nepheline syenite facies. Pyrochlore from the earlier ocelli facies of carbonate-bearing nepheline syenite follow a $\mathrm{Nb}$-Ta differentiation trend, whereas pyrochlore from the younger carbonate-free nepheline syenite follow a more classical $\mathrm{Nb}-\mathrm{Ti}$ trend. Following the 
complete immiscibility between the silicate and carbonatitic liquids, the fractionation between $\mathrm{Nb}$ and Ta stopped while a new generation of $\mathrm{Nb}$-rich pyrochlore grew, displaying a more classical $\mathrm{Nb}$-Ti fractionation trend and a more constant $\mathrm{Nb} / \mathrm{Ta}$ ratio in the nepheline syenite.

KEYWORDS: Immiscibility; Nepheline syenite; Carbonatite; Accessory minerals; Crevier alkaline intrusion 


\section{INTRODUCTION}

Carbonatites often occur in close spatial association with undersaturated alkaline igneous rocks with compositions varying between pyroxenites, nephelinites and/or ijolites, and more evolved nepheline syenites (Le Bas, 1987; Gittins, 1989; Bailey, 1993; Harmer, 1999; Winter, 2001; Mitchell, 2005; Millong \& Groat, 2013). The petrogenetic link between carbonatite and alkaline silicate rocks, both of mantle origin, is still discussed (Bell \& Blenkinsop, 1989; Bell, 1998; Bell et al., 1998; Winter, 2001; Halama et al., 2005, Bell \& Simonetti, 2010; Mollex et al., 2018). Some authors argue that carbonatites represent primary melts extracted from a carbonate-rich mantle source (Wyllie \& Huang, 1976; Wallace \& Green, 1988; Bédard \& Chown, 1992; Dalton \& Wood, 1993; Dalton \& Presnall, 1998; Harmer \& Gittins, 1998; Moore \& Wood, 1998; Brey et al., 2008; Dasgupta et al., 2009; Hammouda et al., 2009). Others plead for fractional crystallization from a $\mathrm{CO}_{2}$-rich parent silicate melt (Watkinson \& Wyllie, 1971; Lee \& Wyllie, 1994; Korobeinikov et al., 1998; Nielsen \& Veksler, 2002; Ulmer \& Sweeney, 2002), or for immiscible separation from a carbonate-bearing silicate melt (Koster van Groos \& Wyllie, 1973; Freestone \& Hamilton, 1980; Kjarsgaard \& Hamilton, 1988; Lee \& Wyllie, 1997; Brooker, 1998; Kjarsgaard, 1998; Veksler et al., 1998a; Halama et al., 2005; Brooker \& Kjarsgaard, 2011; Potter et al., 2017).

Although the immiscibility between silicate and carbonate liquids is poorly documented and only observed in-situ in few localities, it represents an attractive model for the genesis of alkaline silicate-carbonatite complexes (Le Bas, 1987). It has been proposed for a number of occurrences, e.g. the Gardiner complex (Greenland, Nielsen, 1980; Veksler et al., 1998b), the Maoniuping complex (China, Xu et al., 2004), Grønnedal-Ìka (Greenland, Halama et al., 2005; Taubald et al., 2004), Kerimasi (Tanzania, Guzmics et al., 2011), and 
in the Grenville Province at Oka (Quebec, Canada, Treiman \& Essene, 1985). Moreover, in the Kenya rift region, several studies support the hypothesis that the large amount of calcio- to natro-carbonatite volcanic rocks (Nasira, Kerimasi, Shombole, Oldoinyo Lengai) originated from liquid immiscibility (Freestone \& Hamilton, 1980; Kjarsgaard \& Peterson, 1991; Dawson et al., 1994; Kjarsgaard et al., 1995; Church \& Jones, 1995; Veksler et al., 1998b; Mitchell, 2009; Mitchell \& Dawson, 2012; Sharygin et al., 2012; Sekisova et al., 2015; Potter et al., 2017; Mollex, 2017).

Major minerals such as calcite, pyroxene, feldspar and nepheline, are commonly used to trace silicate-carbonate liquid immiscibility, using in-situ mineral chemistry and isotopes (O, Nd) (Bell, 1998; Harmer, 1999; Haynes et al., 2003; Marks et al., 2004a; 2004b; Halama et al., 2005; Guzmics et al., 2008; Guzmics et al., 2012; Morteani et al., 2013). Other studies have used petrographic features coupled to melt inclusions (Nielsen et al., 1997; Mitchell, 2009; Guzmics et al., 2011, 2012; Sekisova et al., 2015; Potter et al., 2017, Baudoin et al., 2018), isotopic constraints (Bell, 1998; Xu et al., 2004; Halama et al., 2005; Li et al., 2016), as well as experimental data (Koster van Groos \& Wyllie, 1963; Lee \& Wyllie, 1996; Suk, 2001; Brooker \& Kjarsgaard, 2011; Veksler et al., 1998a; Veksler et al., 2012) have also been used to trace immiscibility, with variable degrees of success.

The Crevier Alkaline Intrusion (CAl) is located in the central Grenville Province (Quebec, Canada). The intrusion is composed of a suite of undersaturated alkaline rocks that range from ijolite to nepheline syenite and alkaline syenite with comagmatic carbonatites. Therefore, it constitutes a suitable target to investigate silicate-carbonatitic liquid immiscibility. In this study, we present (i) macro- to microscopic textural characterization, (ii) whole-rock geochemistry, (iii) oxygen and carbon stable isotope of carbonates, (iv) major and/or trace element composition of accessory minerals from 
silicate (zircon and pyrochlore) and carbonatite facies (apatite), (v) oxygen isotope of zircon, and (vi) U-Pb dating of zircon and apatite from silicate and carbonatite facies, respectively. We argue that the undersaturated peralkaline silicate rocks and carbonatites of the CAI were produced by/generated through multistage carbonate-silicate immiscibility processes.

\section{THE PROTEROZOIC GRENVILLE PROVINCE}

The Grenville Province, located along the southeastern Laurentian margin in Canada, is composed of Archean and Proterozoic terranes reworked during a major continentcontinent collision during the late-Mesoproterozoic to the early-Neoproterozoic (Fig. 1a; Rivers, 1997; Rivers et al., 2012; Rivers, 2015).The evolution of the Grenville Province can be separated into two major stages: (i) a long-lived active margin built at the margin of southeastern Laurentia from the Paleoproterozoic to the Mesoproterozoic (ca. 1.71 to $1.18 \mathrm{Ga}$ ) where juvenile crust formed at discrete times in arc and back-arc systems (Rivers \& Corrigan, 2000; Whitmeyer \& Karlstrom, 2007; Rivers et al., 2012; Bickford et al., 2015; Groulier et al., 2018a), and (ii) a major continental collision, the Grenvillian Orogeny (ca. 1090 to 960 Ma) (e.g. Rivers, 1997; Rivers et al., 2012; McLelland et al., 2013; Turlin et al., 2018).

\section{FIGURE 1}

\section{The Grenvillian Orogeny}

The Grenvillian Orogeny is recorded as two distinct phases in two distinct tectonometamorphic domains. The Allochthonous Belt is composed of terranes formed outboard of and accreted to the Laurentian margin during the Mesoproterozoic (Rivers et 
al., 2012). This belt records the Ottawan crustal thickening phase (ca. 1090-1020 Ma, e.g. Rivers et al., 2012). The Allochthonous Boundary Thrust (ABT) separates the Allochthonous Belt from the underlying Parautochthonous Belt that corresponds to lithotectonic units of the Superior Province and their cover sequences, and to previously accreted arcs reworked during the Grenvillian Orogeny (Rivers et al., 1989, 2012; Gower \& Krogh, 2002; Groulier et al., 2018a). The Parautochthonous Belt records the Rigolet crustal thickening phase (ca. 1005-960 Ma, Rivers, 2009; Rivers et al., 2012). The Grenvillian orogeny is interpreted to represent one of the best examples of a large, hot and long-duration orogen (LHO, Beaumont et al., 2006; Rivers, 2008, 2009).

Following a syn-Ottawan peak of metamorphism that reached up to granulite-facies conditions, the (i) intrusion of pegmatitic granite dykes at ca. 1005-1000 Ma under close to solidus conditions (Turlin et al., 2018), (ii) titanite cooling ages at ca. 1006-987 Ma (Dunning \& Indares, 2010; Indares \& Dunning, 2018; Groulier et al., 2018b), and (iii) modeled closure temperatures $\left(\sim 550-450{ }^{\circ} \mathrm{C}\right)$ of apatite crystals at ca. $960 \mathrm{Ma}$ (Turlin et al., 2018) document a slow cooling of the medium to low pressure belt (aM-LP, Fig. 1b) at a rate of $\sim 2-6^{\circ} \mathrm{C} / \mathrm{Ma}$. This thermal evolution has been attributed to a lithospheric thinning triggered by slab retreat (Turlin et al., 2018) or to a lithospheric foundering (also referred to delamination; Corrigan \& Hanmer, 1997; Groulier et al., 2018b).

\section{The Grenvillian magmatism}

The two orogenic phases of the Grenvillian Orogeny are marked by the emplacement of intrusive rocks of distinct geochemical affinities. The Ottawan phase induced a voluminous and widespread magmatic activity dominated by Anorthosite-MangeriteCharnockite-Granite (AMCG) and Monzonite-Diorite-Gabbro-Syenite (MDGS) suites (see 
Rivers et al., 2012 and references therein), and potassic to ultrapotassic intrusions that are assumed to be formed by the melting of an enriched and metasomatized mantlesource impacted by the long-lived subduction beneath Laurentia (Corriveau \& Morin, 2000; Rivers et al., 2012 and references therein; Groulier et al., 2018b). The magmatic activity during the Rigolet phase is composed of either parautochthonous- or allochthonous-derived ca. 1005-983 Ma peraluminous pegmatitic granite dykes, and twomicas garnetiferous leucogranite bodies (Groulier et al., 2018b; Turlin et al., 2017, 2019), all of them hosted in the Allochthonous Belt. From ca. 980 to $950 \mathrm{Ma}$, the magmatism evolved towards a more alkaline signature consistent with the emplacement of felsic to minor silica-undersatured intrusion emplaced within the Interior Magmatic Belt of the Allochthonous Belt (Bourne, 1991; Gower et al., 1991, 2008; Rivers, 1997; Gower \& Krogh, 2002).

\section{The Crevier Alkaline Intrusion (CAl)}

The CAI was discovered in 1975 following airborne radiometric surveys and was then carefully studied and mapped using different techniques (drilling campaigns, induced polarization, airborne magnetic survey) leading to the discovery of rare metals $(\mathrm{Nb}, \mathrm{Ta}, \mathrm{U})$

occurrences carried by minerals of the pyrochlore supergroup (Bergeron, 1980; Laplante, 1980; Harrisson, 1981; Bernier \& Moorhead, 2000; Goutier, 2006). The CAI hosts the Crevier deposit, a significant resource of $\mathrm{Nb}$ and Ta with a total tonnage (measured and indicated) of $25.4 \mathrm{Mt}$ grading at $0.2 \mathrm{wt} . \% \mathrm{Nb}_{2} \mathrm{O}_{5}$ and $234 \mathrm{ppm} \mathrm{Ta}$, and of $15.4 \mathrm{Mt}$ inferred resources grading at 0.17 wt. $\% \mathrm{Nb}_{2} \mathrm{O}_{5}$ and $252 \mathrm{ppm} \mathrm{Ta}$ (Duplessis \& Girard, 2010). The property is owned by a joint venture between Niobay Metals Inc. and Niobec Inc. The CAI is emplaced within charnockitic suites and gneisses of the Allochthonous Belt of the 
central Grenville Province (Quebec), north of the Lac Saint-Jean region (Figs. 1 and 2). The CAl outcrops over $25 \mathrm{~km}^{2}$ and is mainly composed of undersaturated peralkaline silicate and carbonatite rocks (Fig. 2b). Following the discovery of this igneous complex, Bergeron (1980) studied the petrology and geochemistry of the different units while Laplante (1980) worked on the $\mathrm{Nb}-\mathrm{Ta}-\mathrm{U}$ mineralization. In addition, Harrisson (1981) obtained a K-Ar age of $879 \mathrm{Ma}$ in rocks from the CAl. Despite the information acquired by these studies, some numerous unknowns still remained, especially regarding the accurate crystallization age of the complex, the nature of its source and of the magmatic processes that led to the coexistence of silicate and carbonatite rocks. The intrusion is oriented N320 (Fig. 2b), following the general orientation of the Waswanipi-Saguenay lineament (Fig. 1b, Bernier \& Moorhead, 2000; Solgadi et al., 2015) that hosts the Paleoproterozoic Montviel (ca. 1894 Ma, David et al., 2006; Goutier, 2006) and the late-Neoproterozoic Saint-Honoré

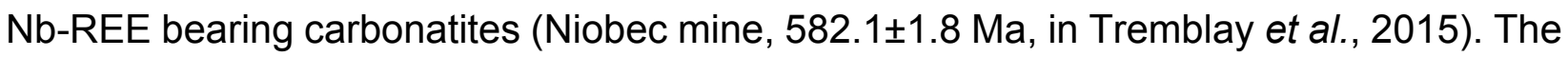
location of these peralkaline complexes with economic importance along a major crustal lineament highlights the importance of such structure during the emplacement of igneous bodies of similar composition.

\section{FIGURE 2}

\section{SAMPLING AND ANALYTICAL METHODS}

\section{Sampling}

Rock material from the CAI sampled for whole-rock geochemistry, U-Pb geochronology, and $\mathrm{O}$ and $\mathrm{C}$ isotopes come from three outcrops striped for exploration, trenches, and delineation drill holes (from North to South CR09-152, CR09-106 and CR09-125, Fig. 2b) made by the property's previous owner Minière Du Nord (MDN) company. Key areas of 
the stripped outcrops were mapped (Fig. 3a; for more details, see Groulier et al., 2014). Samples from the drill holes are representative of the whole alkaline suite (Table 1).

\section{TABLE 1}

\section{Whole-rock geochemistry}

Major elements were measured by ICP-AES (Inductively Coupled Plasma - Atomic Emission Spectrometry) and trace elements by ICP-MS (Inductively Coupled Plasma Mass Spectrometry) by the laboratory Activation Lab (Ancaster, Ontario; sample preparation and digestion methods for geochemistry packages available on http://www.actlabs.com/). Results are reported in Table 2.

\section{TABLE 2}

\section{Electron probe microanalyser (EPMA)}

Major and trace element compositions were measured using a Cameca computer controlled SX-100 equipped with five wavelength dispersive spectrometers (WDS) in the GeoRessouces laboratory (Nancy, France). For all the analyses the beam size was set to

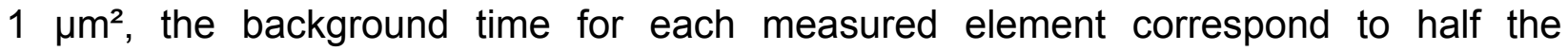
measurement time of the corresponding element, and each X-ray line has been carefully selected in order to prevent peak overlaps and, therefore, interferences.

For quantitative analyses of pyrochlore, major and trace elements $(\mathrm{U}, \mathrm{Th}, \mathrm{Sn}, \mathrm{Sc}, \mathrm{Y}$, La, $\mathrm{Ce}, \mathrm{Mn}, \mathrm{Ca}, \mathrm{Sr}, \mathrm{Ba}, \mathrm{Pb}, \mathrm{Na}, \mathrm{K}, \mathrm{W}, \mathrm{Nb}, \mathrm{Ta}, \mathrm{Si}, \mathrm{Ti}, \mathrm{Zr}, \mathrm{Al}, \mathrm{Fe}, \mathrm{F}$ ) were measured using an accelerating voltage of $20 \mathrm{kV}$ and a beam current of $20 \mathrm{nA}$. Peak counting time was set to $10 \mathrm{~s}$ for $\mathrm{Na}, \mathrm{Al}, \mathrm{Si}, \mathrm{K}, \mathrm{Ca}, \mathrm{Ti}, \mathrm{Mn}, \mathrm{Fe}, \mathrm{Sr}, \mathrm{Y}, \mathrm{Zr}, \mathrm{Nb}, \mathrm{Sn}, \mathrm{Ta}, \mathrm{W}$, Th and $20 \mathrm{~s}$ for $\mathrm{Ba}$, $\mathrm{La}, \mathrm{Ce}, \mathrm{Pb}, \mathrm{U}, \mathrm{F}$. Standards used for these measurements were uraninite $(\mathrm{U})$, thorianite 
(Th), cassiterite (Sn), Sc metal (Sc), Y-monazite (Y), monazite ( $\mathrm{La}, \mathrm{Ce})$, geikielite (Mn, Ti), andradite $(\mathrm{Ca})$, celestite $(\mathrm{Sr})$, baryte $(\mathrm{Ba})$, galena $(\mathrm{Pb})$, albite $(\mathrm{Na}, \mathrm{Si})$, orthoclase $(\mathrm{K}), \mathrm{W}$ metal (W), $\mathrm{LiNbO}_{3}(\mathrm{Nb}), \mathrm{LiTaO}_{3}(\mathrm{Ta})$, zircon ( $\left.\mathrm{Zr}\right)$, corundum (Al), hematite (Fe), F-apatite (F). The calculation correction used was PAP (Pouchou \& Pichoir, 1991) and the pyrochlore composition was calculated following the formula $A_{2-m} B_{2} X_{6-w} Y_{1-n}$ from Atencio et al. (2010) with $\mathrm{m}, \mathrm{w}$ and $\mathrm{n}$ corresponding to the vacancies on the different sites. The cations $\mathrm{U}^{4+}, \mathrm{Th}^{4+}, \mathrm{Sn}^{4+}, \mathrm{Sc}^{3+}, \mathrm{Y}^{3+}, \mathrm{La}^{3+}, \mathrm{Ce}^{3+}, \mathrm{Mn}^{2+}, \mathrm{Ca}^{2+}, \mathrm{Sr}^{2+}, \mathrm{Ba}^{2+}, \mathrm{Pb}^{2+}, \mathrm{Na}^{+}$and $\mathrm{K}^{+}$ were attributed to the A-site, $\mathrm{W}^{6+}, \mathrm{Nb}^{5+}, \mathrm{Ta}^{5+}, \mathrm{Si}^{4+}, \mathrm{Ti}^{4+}, \mathrm{Zr}^{4+}, \mathrm{Al}^{3+}$ and $\mathrm{Fe}^{3+}$ were attributed to the B-site, while $\mathrm{F}^{-}$and $\mathrm{OH}^{-}$were attributed to the $\mathrm{X} / \mathrm{Y}$-sites. The results for pyrochlore are summarized in Table 3 and detailed in Table S1.

\section{TABLE 3}

For quantitative analyses of apatite, major and trace elements $(\mathrm{P}, \mathrm{Ca}, \mathrm{Cl}, \mathrm{F}, \mathrm{Na}, \mathrm{Si}, \mathrm{Mg}$, $\mathrm{Fe}, \mathrm{Sr}, \mathrm{Y}, \mathrm{Eu}, \mathrm{Dy}, \mathrm{Yb}, \mathrm{S}, \mathrm{Mn}, \mathrm{Zr}$, La, Ce, Nd, Sm, Gd, Pb, Th, U) were measured using an accelerating voltage of $15 \mathrm{kV}$ and a beam current of $12 \mathrm{nA}$. Peak counting time was set to $10 \mathrm{~s}$ for each element. The standards used for these measurements were apatite $(\mathrm{Ca}$, $\mathrm{P})$, albite ( $\mathrm{Na}, \mathrm{Si})$, olivine $(\mathrm{Mg}, \mathrm{Fe})$, celestite $(\mathrm{Sr})$, geikielite $(\mathrm{Mn})$, monazite $(\mathrm{La}, \mathrm{Ce}, \mathrm{Nd})$, baryte $(\mathrm{S})$, topaz $(\mathrm{F})$, vanadinite $(\mathrm{Cl})$. Formula units were calculating based on 12.5 oxygens, based on an ideal formula of $\mathrm{Ca}_{5}\left(\mathrm{PO}_{4}\right)_{3}(\mathrm{~F}, \mathrm{Cl}, \mathrm{OH})$. The cations $\mathrm{Ca}^{2+}, \mathrm{Na}^{+}, \mathrm{Mg}^{2+}$, $\mathrm{Fe}^{3+}, \mathrm{Sr}^{2+}, \mathrm{Mn}^{2+}, \mathrm{La}^{3+}, \mathrm{Ce}^{3+}$ and $\mathrm{Nd}^{3+}$ were attributed to the Ca-site, $\mathrm{P}^{5+}, \mathrm{Si}^{2+}$ and $\mathrm{S}^{6+}$ were attributed to the $\mathrm{P}$-site, while $\mathrm{F}^{-}$and $\mathrm{Cl}^{-}$were attributed to the $\mathrm{F}$-site. The results for apatite are provided in Table 4.

\section{TABLE 4}


Trace element analyses of zircon using laser ablation-inductively coupled plasmasector field-mass spectrometry (LA-ICP-SF-MS)

Trace element analyses were carried out on zircon grains from the carbonate-bearing coarse-grained nepheline syenite (sample 12-PA-011-B11) at the Goethe University of Frankfurt (Germany), using laser ablation-inductively coupled plasma-sector field-mass spectrometry (LA-ICP-SF-MS). The laser spot size and the repetition rates were set to 50 $\mu \mathrm{m}$ and $5.5 \mathrm{~Hz}$, respectively. Analysis time for each spot was overall $90 \mathrm{~s}$, with $30 \mathrm{~s}$ washout, $30 \mathrm{~s}$ for the background (no ablation) and $30 \mathrm{~s}$ for the sample. The intensities of the following isotopes were recorded: ${ }^{44} \mathrm{Ca},{ }^{49} \mathrm{Ti},{ }^{57} \mathrm{Fe},{ }^{88} \mathrm{Sr},{ }^{139} \mathrm{La},{ }^{140} \mathrm{Ce},{ }^{141} \mathrm{Pr},{ }^{146} \mathrm{Nd}$, ${ }^{147} \mathrm{Sm},{ }^{151} \mathrm{Eu},{ }^{157} \mathrm{Gd},{ }^{158} \mathrm{Gd},{ }^{159} \mathrm{~Tb},{ }^{161} \mathrm{Dy},{ }^{165} \mathrm{Ho},{ }^{167} \mathrm{Er},{ }^{169} \mathrm{Tm},{ }^{172} \mathrm{Yb},{ }^{175} \mathrm{Lu},{ }^{232} \mathrm{Th}$, and ${ }^{238 \mathrm{U}}$.

The GJ-1 zircon, NIST SRM-612 and NIST SRM-614 reference materials were monitored as standards during the analytical session. Relative errors obtained for the analyzed trace elements on reference material are between 2 and $8 \%$ ( 1 sigma). Raw data of LA-ICPSF-MS analyses were processed using the software GLITTER ${ }^{\text {TM }}$ (Griffin et al., 2008). Results are summarized in Table 5 and detailed results are proposed in Table S2.

\section{TABLE 5}

\section{U-Pb dating on zircon and apatite using LA-ICP-(SF-)MS}

$\mathrm{U}-\mathrm{Pb}$ analyses of zircon grains from the carbonate-bearing coarse-grained nepheline syenite (sample 12-PA-011-B11) were carried out by LA-ICP-SF-MS at the Goethe University of Frankfurt (Germany). Methods and instruments were described by Gerdes \& Zeh (2006, 2009), with modifications explained in Zeh \& Gerdes (2012). Results are summarized in Table 5 and detailed results for unknowns and standard measurements are provided in Table S3. 
$\mathrm{U}-\mathrm{Pb}$ analyses of apatite grains from carbonatites were carried out by LA-ICP-MS directly on thin sections at Géosciences Rennes (France) using an ESI NWR193UC excimer $193 \mathrm{~nm}$ laser coupled to a quadripole Agilent 7700x ICP-MS. Methods and instruments were described by Pochon et al. (2016), the operating conditions are given in Table S4. Results are listed in Table 6.

\section{TABLE 6}

\section{In-situ ion probe oxygen isotope of zircon}

Ion probe oxygen isotope analyses were performed at the Centre de Recherches Pétrographiques et Géochimiques (CRPG, Nancy, France) using the Cameca IMS 1270. Secondary lon Mass Spectrometry (SIMS) oxygen isotope analyses of zircon were carried out using a $\mathrm{Cs}^{+}$primary ion beam accelerated at $10 \mathrm{kV}$ with an intensity of $10 \mathrm{nA}$. The ${ }^{16} \mathrm{O}$ and ${ }^{18} \mathrm{O}$ ion intensities were measured simultaneously in multi-collection mode using two off-axis Faraday cups, as described in detail in Nemchin et al. (2006). Oxygen isotope are reported in $\delta^{18} \mathrm{O}$ notation as per mil deviation from the ${ }^{18} \mathrm{O} /{ }^{16} \mathrm{O}$ of $\mathrm{V}-\mathrm{SMOW}$. The analyses were corrected for the instrumental mass fractionation using the 91500-zircon standard with a $\delta^{18} \mathrm{O}$ value of $9.86 \%$ (Wiedenbeck et al., 2004) to which the data for unknowns was normalized. Results are summarized in Table 5 and detailed results are listed in Table S5.

\section{Oxygen and Carbon isotope analyses of carbonates}

Coarse-grained calcite texture from the carbonatite facies was crushed with pestle and mortar to obtain powders. A mass of 11 to $12 \mathrm{mg}$ of calcite powder was digested in anhydrous phosphoric acid $\left(\mathrm{H}_{3} \mathrm{PO}_{4}\right)$ in a double bottom reactor at a temperature of $50^{\circ} \mathrm{C}$ 
during a few hours in order to complete the reaction. Analyses on the recovered $\mathrm{CO}_{2}$ gas were realized on a VG Optima triple collector mass spectrometer at Géosciences Rennes (France). The long term analysis of in-house standard Prolabo Rennes and international standard NBS 18 (Fen carbonatite) allows estimating the overall uncertainty at $\pm 0.20 \%$ for $O$ and $\pm 0.10 \%$ for $C$. The results are listed in Table 7 .

\section{TABLE 7}

\section{FIELD RELATIONSHIPS}

The previous work of Bergeron (1980) identified a complex assemblage of various types of silica-undersaturated rocks in the Crevier Alkaline Intrusion (CAI). An updated characterization of the main lithologies/facies constitutive of the intrusion was based on airborne aeromagnetic data, detailed mapping, drill-core logging, exploration trenches and stripped outcrops (Figs. 2b, 3a-c). They are described below following their relative timing of emplacement.

\section{Carbonate-bearing fine to coarse-grained nepheline syenite}

The outer nepheline syenite (Fig. 2b) corresponds to a polyphase intrusive body with different facies from fine- to dominant coarse-grained texture (Fig. 3a). The coarsegrained type is carbonate-bearing and the dominant feldspathoid is nepheline but some

grains of cancrinite and sodalite have been observed in drill cores. It forms most of the intrusion and is crosscut by fine- to medium-grained nepheline syenite dykes which are randomly injected (Fig. 3b). The rocks do not exhibit any evidence of solid-state deformation. 


\section{Banded core}

The banded core is oriented N320 (Fig. 2b) and interpreted to represent parallel dykes by Bergeron (1980). The banded core is composed of four main facies, namely (i) ijolite-urtite (ijolite consists of pyroxene and 30 to $70 \%$ modal nepheline while urtite are leuco-ijolite with more than $70 \%$ modal nepheline; Le Maitre, 2002), (ii) silicocarbonatite, (iii) nepheline syenite, and (iv) calcio- and ferrocarbonatite.

\section{Silicocarbonatites}

Outside of the banded core, the silicocarbonatites appear as dykes that crosscut the outer nepheline syenite (Fig. 3a, c). They are crosscut by the pegmatitic nepheline syenite dyke swarms (Fig. 3a, c) and by calcio- and ferro-carbonatites (Fig. 3h).

\section{Pegmatitic nepheline syenite dyke swarms}

Both the banded core and the surrounding nepheline syenite are crosscut in their center by a dyke swarm of pegmatitic nepheline syenite (Figs. 2b, 3a-d, 3f) and carbonatite (Figs. 3a, 3c, 3e-h). The dyke swarms of pegmatitic nepheline syenite are oriented N320, i.e. parallel to the banded core and to the general orientation of the CAI, with an average dip of $80^{\circ}$ toward the North-East. They correspond to the main economic target due to their high $\mathrm{Nb}$ and Ta contents. Detailed mapping showed that these dykes were emplaced en echelon with an apparent dextral shear-movement (Fig. 3a). The dykes are characterized by margins of megacrystic nepheline and albite (up to $50 \mathrm{~cm}$ long) together with dark mica crystallizing inward from the dyke walls (Fig. 3d). The center of the dykes (feeder conduits) is composed of fine-grained nepheline syenite which corresponds to the liquid from which the pegmatitic nepheline syenite crystallized. In the dyke swarms, two facies of nepheline 
syenite can be differentiated based on their mineralogy and field relationships. The (1) most primitive (oldest) facies corresponds to carbonate-bearing nepheline syenite characterized by the presence of magmatic carbonates. One of the feeder conduits display a spectacular ocelli texture with spheres of carbonate-bearing nepheline syenite rimmed by dark mica in a carbonatite and apatite matrix (Fig. 4a-c). The (2) youngest facies correspond to a carbonate-free nepheline syenite which seems to be contemporaneous with the carbonatites. Both the carbonate-bearing and carbonate-free nepheline syenites are enriched in $\mathrm{Nb}$ and $\mathrm{Ta}$ as shown by the presence of pyrochlore as an accessory phase.

\section{Calcio- and ferro-carbonatites}

In the southern part of the CAI the carbonatites appear as dykes (Fig. 3a, 3c) or veins closely associated with the dyke swarms of pegmatitic nepheline syenite (Fig. 3f). They are more abundant in the central and northern parts (banded core) of the CAI where they can form homogeneous bodies and dykes. The dominant calciocarbonatite and the more evolved ferrocarbonatite represent the youngest types of carbonatites within the complex (Fig. 3e, g).

\section{Nepheline-bearing alkali syenite and syenite}

In the southern part of the complex a small stock of nepheline-bearing alkali syenite and syenite crosscut a fine to coarse-grained nepheline syenite that will not be further discussed in the manuscript (Fig. 2b).

\section{FIGURE 3}




\section{PETROGRAPHY}

\section{ljolite-urtite}

The ijolite-urtite series of the banded core of the CAI is a fine-grained rock with a porphyritic texture marked by the presence of euhedral nepheline and perthitic alkalifeldspar phenocrysts with Carlsbad twins (Fig. 4d). The groundmass is composed of an assemblage of nepheline-alkali feldspar-phlogopite-aegirine with primary calcite. Accessory minerals are represented by euhedral titanite and interstitial Fe-Ti oxides. As the aegirine represents around $10 \%$ of the whole assemblage, this rock is designated as leuco-ijolite based on the classification of Mitchell (1996), and as urtite or ijolite based on the percentage of nepheline (30-70\% in this case) according to the classification of Platt (1996).

\section{FIGURE 4}

\section{Nepheline syenite}

The dominant lithology found in the CAI is a holocrystalline and equigranular coarsegrained nepheline syenite that corresponds to the outer rim of the complex (Figs. 2b, 4e). Alkali feldspar is albite dominant, but perthitic orthoclase are commonly observed together with minor microcline. The grains commonly display undulose extinction, twin deformation and grain boundary migration. Nepheline is commonly altered into cancrinite, some grains of sodalite were observed in drill cores. In addition, in some facies, abundant primary carbonates (calcite) are found as interstitial phases either at the edges of nepheline and feldspar crystals or as inclusions in the perthitic feldspars, making them carbonate-bearing nepheline syenites (Fig. 4e-f, Table 2). 
The coarse-grained nepheline syenite is crosscut by fine- to medium-grained nepheline syenite injections, the mineralogy of which is similar to the coarse-grained nepheline syenite. Some dykes display medium-grained centers and fine-grained margins interpreted as chilled margins suggesting a difference in temperature between the cooler host rock and the intruding magma.

\section{Pegmatitic nepheline syenite and their fine-grained feeder conduits}

The pegmatitic part is characterized by centimeter-size crystals of albite, alkali feldspar, nepheline and dark mica with minor proportions of sodalite and carbonates. Nepheline is often altered in cancrinite and the observed accessory minerals are zircon, pyrochlore, pyrite, pyrrhotite and Fe-Ti oxides. The center of the dykes is composed of fine-grained nepheline syenite with variable amounts of carbonate and mica. A weak magmatic foliation underlined by the albite lattes gives to the rock a fluidal, almost trachytic, texture. The feeder conduits are mostly composed of alkali feldspar, albite and nepheline and they are highly enriched in pyrochlore (up to $6 \%$, Fig. $4 \mathrm{~g}$ ). Parts of the dyke swarms display evidence of magmatic-hydrothermal alteration such as crosscutting sodalite veins, nepheline with rims of cancrinite, hematization and carbonation. These zones are characterized by a modal enrichment in pyrochlore and zircon. The presence of carbonates makes the distinction between the older carbonate-bearing and the younger carbonate-free groups.

\section{Ocelli facies}

This facies was observed in only one location. It represents a feeder conduit of a pegmatitic nepheline syenite dyke within one of the dyke swarms. This particular texture 
is characterized by spheres of fine-grained and dark mica- and carbonate-bearing nepheline syenite rimmed by mica in a carbonatite and apatite matrix (Figs. 3a, 4a-c). In this facies, pyrochlore grains are observed only within the spheres of nepheline syenite.

\section{Silicocarbonatite}

The silicocarbonatites are melanocratic due to a high modal proportion of dark mica $(>40 \%)$ and are characterized by magmatic carbonate (>10\%), plagioclase, aegirine with varying proportions in Fe-Ti oxides and accessory minerals (zircon, apatite; Fig. 3c, h).Two types of silicocarbonatite are observed in the intrusion: one is enriched in $\mathrm{Fe}-\mathrm{Ti}$ oxides, and the other one is enriched in aegirine (Fig. 4h). The silicocarbonatites show a strong magmatic foliation underlined by micas $\{001\}$ cleavage planes and they can be enriched in apatite. These silicocarbonatites form layers in the banded-core and dykes in the outer rim of nepheline syenite of the intrusion (Fig. 3a, c).

\section{Carbonatite}

On the basis of their texture and chemical composition (mainly Fe), the carbonatites are divided in two types: (i) a fine- to coarse-grained calciocarbonatite dominated by calcite (sövite composition; Figs. 3g, 4i), and (ii) a coarse-grained ferrocarbonatite composed of an assemblage of ankerite, calcite, hematite, and fluorapatite. Interstitial silicate phases such as phlogopite develop at the walls of the carbonatite veins/dykes when crosscutting the nepheline syenite. The two facies are pyrochlore-poor but contain fluorapatite (Fig. 4i), strontianite, REE-carbonates and monazite. Some calciocarbonatites are enriched in sulfides (pyrrhotite, chalcopyrite, molybdenite and argentite) and tellurides. 
An envelope of fenitization is marked by the metasomatic crystallization of albite and arfverdsonite in the surrounding rocks (Fig. 2b). This process of fenitization is not further considered in this contribution.

\section{WHOLE-ROCK GEOCHEMISTRY}

In the total alkali versus silica (TAS) diagram (Fig. 5a; Middlemost, 1994), the ijolite-urtite has an intermediate composition between the nepheline syenite and silicocarbonatite lithologies with an alkali content of 11.8 wt.\% and a silica content of 43.8 wt.\% (Fig. 5a, Table 2). The nepheline syenite defines a geochemical trend with increasing alkali $\left(\mathrm{Na}_{2} \mathrm{O}\right.$ $+\mathrm{K}_{2} \mathrm{O}$ from 11.5 to 16.3 wt.\%) and silica $\left(\mathrm{SiO}_{2}\right.$ from 46.4 to 59.8 wt.\%) contents. The carbonate-bearing nepheline syenite are generally less evolved and fall in the nepheline monzosyenite fields with lower alkali and silica contents. The silicocarbonatite has lower alkali (from 7.7 to $9.6 \mathrm{wt} . \%$ ) and silica $\left(\mathrm{SiO}_{2}\right.$ from 32.5 to 42.4 wt.\%) contents, with higher $\mathrm{Fe}_{2} \mathrm{O}_{3(\mathrm{t})}$ (from 4.53 to 16.4 wt. \%) and $\mathrm{CaO}$ (from 6.6 to 12.7 wt.\%, Fig. 5, Table 2) contents. The carbonatites ( $\mathrm{CaO}$ from 49.8 to $52.4 \mathrm{wt} . \%$ ) are not represented on this TAS diagram due to their very low $\mathrm{SiO}_{2}$ content (ranging from 0.2 to $3.2 \mathrm{wt} . \%$, Table 2). Their Mg number $\left(\mathrm{MgO} /\left[\mathrm{Fe}_{2} \mathrm{O}_{3(\mathrm{t})}+\mathrm{MgO}\right]^{*} 100\right)$ ranges from 30 to 45 (Table 2).

In the A vs B chemical-mineralogical diagram of Debon \& Lefort (1988), the evolution from the ijolite towards the nepheline syenite is mineralogically expressed as an enrichment in nepheline, alkali feldspar and plagioclase and a decrease in clinopyroxene (Fig. 5b). Conversely, the ferro- and silico-carbonatite is associated with an enrichment in dark micas, and the calciocarbonatite with an enrichment in calcite (Fig. 5b).

\section{FIGURE 5}


The different lithologies display different features in Harker diagrams (Figs. 6a-d, see also Table 2). The nepheline syenite is characterized by high values in $\mathrm{Na}_{2} \mathrm{O}$ (from 6.4 to 12.6 wt.\%) and $\mathrm{Al}_{2} \mathrm{O}_{3}$ (from 16 to 25 wt.\%), and low contents of $\mathrm{MgO}$ (usually $<1$ wt.\%) and $\mathrm{CaO}$ (from 0.3 to $10.4 \mathrm{wt}$ \%). The silicocarbonatite is enriched in $\mathrm{MgO}$ (from 1.5 to 9.4 wt.\%), $\mathrm{TiO}_{2}$ (from 0.7 to 4.9 wt.\%), and $\mathrm{CaO}$ (from 6.6 to 12.7 wt.\%), and has lower $\mathrm{SiO}_{2}$ (between 32 and 43 wt.\%) and $\mathrm{Al}_{2} \mathrm{O}_{3}$ (between 10 and 16 wt.\%) contents. The carbonatites are enriched in $\mathrm{CaO}$ (>28 wt.\%), $\mathrm{Sr}$ (up to $9343 \mathrm{ppm}$ ) and $\mathrm{REE}$ ( $\sum \mathrm{REE}$ up to 1414 ppm) with low $\mathrm{SiO}_{2}(<4$ wt. $\%), \mathrm{Na}_{2} \mathrm{O}(<1$ wt. $\%)$, and $\mathrm{Al}_{2} \mathrm{O}_{3}(<2$ wt. $\%)$ contents (Table 2). The ijolite facies displays an intermediate composition between the nepheline syenite and the silicocarbonatite, with $\mathrm{SiO}_{2}, \mathrm{Al}_{2} \mathrm{O}_{3}, \mathrm{MgO}, \mathrm{CaO}, \mathrm{Na}_{2} \mathrm{O}$ and $\mathrm{TiO}_{2}$ contents of 43.8 wt.\%, 17.4 wt.\%, 1.0 wt.\%, 11.1 wt.\%, 7.0 wt.\%, and 0.7 wt.\% (Fig. 6 and Table 2), respectively. The carbonate-bearing nepheline syenites show compositions that are closer to the ijolite than to the carbonate-free ones.

\section{FIGURE 6}

The ijolite contains a $\Sigma$ REE content of $62 \mathrm{ppm}$ and shows a chondrite-normalized REE pattern marked by an enrichment in the LREE relative to the HREE $\left([\mathrm{La} / \mathrm{Yb}]_{\mathrm{N}}=12\right.$, Fig. 7 , Table 2). The carbonate-free nepheline syenites contain $\Sigma$ REE contents between 27 and $133 \mathrm{ppm}$ (Table 2). They are variably enriched in LREE relative to chondrite $\left([\mathrm{La} / \mathrm{Yb}]_{\mathrm{N}}=\right.$ 7.6-65, Fig. 7, Table 2) and they tend to have flat to slightly fractionated HREE chondritenormalized patterns $\left([\mathrm{Gd} / \mathrm{Yb}]_{N}=0.8-6.3\right.$, Fig. 7, Table 2). The carbonate-bearing nepheline syenites are overall more enriched in REE than the carbonate-free nepheline syenites with $\Sigma$ REE contents between 121 and $319 \mathrm{ppm}$ (Table 2). The silicocarbonatite and carbonatite are more enriched in REE, the former showing $\mathrm{REEE}$ contents between 
274 and 543 ppm, and the latter showing $\Sigma$ REE contents between 1189 and 1414 ppm (Table 2). Both show a relative enrichment of the LREE compared to HREE in their chondrite-normalized patterns as shown by their $[\mathrm{La} / \mathrm{Yb}]_{N}$ of 19-37 and 19-32, respectively (Fig. 7, Table 2).

\section{FIGURE 7}

\section{TEXTURAL AND GEOCHEMICAL CHARACTERISTICS OF ACCESSORY MINERALS}

\section{Apatite}

Apatite is present in both the silicocarbonatite and carbonatite facies. Grains are (sub)euhedra and range in size from ca 0.2 to $2.0 \mathrm{~mm}$, but some display slight dissolution textures on the rims (Fig. 8a-b). They are rather homogeneous as shown by their $\mathrm{CaO}$ and $\mathrm{P}_{2} \mathrm{O}_{5}$ contents of $54.90 \pm 0.13$ wt. $\%$ and of $43.03 \pm 0.15$ wt.\% (Table 4), respectively, and are fluorapatite with an homogeneous $\mathrm{F}$ content of $3.16 \pm 0.04$ wt.\% (Table 4). They plot in the carbonatitic field defined by Piccoli et al. (2002) (Fig. 8c-e), and are thus considered of magmatic origin.

\section{FIGURE 8}

\section{Pyrochlore}

Previous studies have distinguished two types of pyrochlore, namely (i) primary magmatic grains with complex zoning (Fig. 9a) and (ii) secondary grown or extensively altered grains during the circulation of a magmatic-hydrothermal fluid with dissolution/reprecipitation zones (Groulier et al., 2014). For the purpose of this study we only focus on the magmatic pyrochlore in the studied rock types. 
Magmatic pyrochlore is dominantly found in the late nepheline-bearing facies, and particularly within the dyke swarms of pegmatitic nepheline syenite. Even though silicocarbonatite contains some pyrochlore, it is very rare in the carbonatites. The few observed are small in size $(\leq 10 \mu \mathrm{m})$ and highly metamict due to high $U$ content, so that any EPMA analysis is difficult to undertake. Primary magmatic pyrochlore from the pegmatitic dyke swarms of nepheline syenites is euhedral and generally larger than 100 $\mu \mathrm{m}$ (Fig. 9a, average of $500 \mu \mathrm{m}$ and up to ca. $2 \mathrm{~mm}$ ). In the pegmatitic nepheline syenites, the pyrochlore grains are located along the edges of the megacrystic nepheline and albite where it is generally in spatial association with fluorapatite and ilmenite. They appear as disseminated grains within the fine-grained feeder conduits. The pyrochlore grains observed in the ocelli facies are found within the spheres of carbonate-bearing nepheline syenite where they are associated with carbonates and fluorapatite. BSE images reveal that the majority of the primary magmatic pyrochlore grains from all the different facies exhibit magmatic inclusions with complex zoning (Fig. 9a).

All the investigated magmatic grains plot in the pyrochlore field with $\mathrm{Nb}^{5+}+\mathrm{Ta}^{5+}>2 \mathrm{Ti}^{4+}$ and $\mathrm{Nb}^{5+}>\mathrm{Ta}^{5+}$ (Hogarth, 1977; Fig. 9b). Two trends are noticeable: (i) a Nb-Ti trend with relatively constant Ta content in pyrochlore from the carbonate-poor to free pegmatitic nepheline syenite and their feeder conduits, and (ii) a $\mathrm{Nb}-\mathrm{Ta}$ trend with constant $\mathrm{Ti}$ concentrations in the ocelli facies (Fig. 9b). Pyrochlore from the carbonate-poor to free nepheline syenite facies has $\mathrm{Nb}_{2} \mathrm{O}_{5}$ contents ranging from 52.50 to 67.24 wt.\% (mean of 61.49 wt. \%), $\mathrm{Ta}_{2} \mathrm{O}_{5}$ from 0.83 to 9.54 wt.\% (mean of 6.23 wt. \%), $\mathrm{TiO}_{2}$ from 0.83 to 5.39 wt. \% (mean of $2.77 \mathrm{wt} . \%$ ) and $\mathrm{UO}_{2}$ below $0.16 \mathrm{wt.} \%$ (mean of $0.01 \mathrm{wt} . \%$ ). The pyrochlore from the carbonate-bearing ocelli facies has $\mathrm{Nb}_{2} \mathrm{O}_{5}$ contents ranging from 53.22 to 64.48 
wt. $\%$ (mean of 57.92 wt.\%), $\mathrm{Ta}_{2} \mathrm{O}_{5}$ from 4.77 to 16.06 wt. $\%$ (mean of 11.87 wt.\%), $\mathrm{TiO}_{2}$ from 1.21 to 2.66 (mean of 1.79 wt.\%), and $\mathrm{UO}_{2}$ below 1.94 wt.\% (mean of $0.52 \mathrm{wt.} \%$ ) (Tables 3 and S1).

In the $\mathrm{Ta}^{5+} \mathrm{vs} \mathrm{Ti}^{4+}$ diagram (Fig. 9c), the pyrochlore from the ocelli facies define a trend marked by an increase of the Ta content with minor variation in Ti implying a dominant $\mathrm{Nb}^{5+}=\mathrm{Ta}^{5+}(1)$ isomorphic substitution due to the solid solution between pyrochlore $\left[\mathrm{CaNaNb}_{2} \mathrm{O}_{6}(\mathrm{OH}, \mathrm{F})\right]$ and microlite $\left[\mathrm{CaNaTa}_{2} \mathrm{O}_{6}(\mathrm{OH}, \mathrm{F})\right]$ (Hogarth, 1977; Nasraoui \& Bilal, 2000; Atencio, 2010). This isomorphic substitution is responsible for the negative correlation between $\mathrm{Nb}$ and Ta (Fig. 9d), and for the variable $\mathrm{Nb}$ contents with constant Ti (Fig. 9e).

In the $\mathrm{Ta}$ vs $\mathrm{Ti}$ diagram (Fig. 9c), the pyrochlore from the carbonate-poor to free nepheline syenite follow a second trend characterized by an increasing Ti content with constant Ta implying a substitution between $\mathrm{Nb}$ and $\mathrm{Ti}$. In the Ta vs $\mathrm{Nb}$ diagram (Fig. 9d), the pyrochlore from the carbonate-poor to free nepheline syenites show variations in the $\mathrm{Nb}$ content with no to few variations in the Ta content. They also display a linear negative correlation between $\mathrm{Nb}$ and $\mathrm{Ti}$ (Fig. 9e). The evolution of the $\mathrm{Ta}, \mathrm{Nb}$ and Ti contents marks the replacement of $\mathrm{Nb}^{5+}$ by $\mathrm{Ti}^{4+}$ and the involvement of $\mathrm{Na}^{+}$and $\mathrm{Ca}^{2+}$ following the reaction $\mathrm{Ca}^{2+}+\mathrm{Ti}^{4+}=\mathrm{Na}^{+}+\mathrm{Nb}^{5+}(2)$. This substitution scheme is dominant for the pegmatitic carbonate-poor to free nepheline syenite facies. It illustrates the solid solution between betafite $\left[\mathrm{CaNaTi}_{2} \mathrm{O}_{6}(\mathrm{OH}, \mathrm{F})\right]$ and pyrochlore $\left[\mathrm{CaNaNb}_{2} \mathrm{O}_{6}(\mathrm{OH}, \mathrm{F})\right]$ (Hogarth, 1977; Nasraoui \& Bilal, 2000; Atencio, 2010).

\section{FIGURE 9}

\section{Zircon}


Zircon grains from the carbonate-bearing coarse-grained nepheline syenite (sample 12PA-011-B1, outer nepheline syenite from Fig. 2b) can be separated in two main populations based on their textures and chemical compositions. The dominant population corresponds to (sub-)euhedral zircon grains with lengths ranging from 100 to $950 \mu \mathrm{m}$ and aspect ratios of 1:1 to 1:2 (Figs. 10a and 11a). The CL (CathodoLuminescence) images reveal oscillatory zoned cores truncated by CL-bright rims of irregular shape perhaps formed by coupled dissolution-reprecipitation (Figs. 10a and 11a). The second population corresponds to anhedral zircon grains with lengths ranging from ca. 250 to $700 \mu \mathrm{m}$ and aspect ratios of $1: 1$ to $1: 2$ (Figs. $10 \mathrm{c}$ and $11 \mathrm{c}$ ). The $\mathrm{CL}$ images reveal complex oscillatory zoning and local dissolution-reprecipitation rims (Figs. 10c and 11c). No mineral inclusions have been observed in all zircon populations even using the highest SEM resolution in the range of ca. $50 \mathrm{~nm}$.

The (sub-)euhedral and anhedral zircon grains show contrasting geochemical features. The (sub-)euhedral zircons show higher Th/U ratios (generally greater than 1 and up to 6.8), $\mathrm{Ca}+\mathrm{Fe}$ contents (up to $28005 \mathrm{ppm}$ ), $\Sigma$ LREE (up to $301 \mathrm{ppm}$ ), $\mathrm{Sr}$ (up to $2460 \mathrm{ppm}$ ) and $\mathrm{Ti}$ (up to $1536 \mathrm{ppm}$ ) contents, compared to the anhedral zircons with lower Th/U ratios (generally below 1 and down to 0.12 ) and $\mathrm{Ca}+\mathrm{Fe}$ contents (down to $77 \mathrm{ppm}$ ), $\Sigma$ LREE (between 0.5 and $16 \mathrm{ppm}$ ), Sr (between 0.1 and $25 \mathrm{ppm}$ ), and Ti (between 1.6 and 14 ppm) (Figure 12a-e, Table 5).

The REE chondrite-normalized patterns of anhedral zircon grains are characterized by (i) significantly higher HREE relative to LREE ([Sm/Yb] from 0.01 to 0.22$)$ independent from the $\mathrm{Ca}$ and Fe contents (Fig. 12e, Table 5), (ii) a positive $\mathrm{Ce}$ anomaly (Ce/Ce ${ }^{*}$ from 1.31 to 25.83 ), and (iii) $\mathrm{Eu}\left(\mathrm{Eu} / \mathrm{Eu}^{*}\right.$ from 0.54 to 1.05 ) anomalies (Fig. 12f, Table 5). In the (sub-)euhedral zircon grains the REE patterns are highly variable and become flatter with 
increasing $\mathrm{Ca}+\mathrm{Fe}$ and $\Sigma$ LREE contents, as indicated by $[\mathrm{Sm} / \mathrm{Yb}]_{N}$ between 0.01 and 0.20 , $\mathrm{Ce} / \mathrm{Ce}^{*}$ between 1.28 and 14.04, and Eu/Eu* between 0.29 and 1.04(Fig. 12e-f, Table 5). It is pertinent to note that trace element analyses obtained from cores and rims of the two (sub-)euhedral zircon grains cover nearly the entire compositional range estimated on all anhedral and (sub)euhedral zircon grains, whereby the cores commonly show higher contents in zircon-incompatible elements ( $\mathrm{Ca}, \mathrm{Fe}, \mathrm{LREE}, \mathrm{Sr}$ ) compared to the related rims (Fig. 12).

\section{FIGURE 10 \\ FIGURE 11 \\ FIGURE 12}

\section{Zircon crystallization temperatures}

Temperatures calculated by applying the Ti-in-zircon geothermometer calibrated by Ferry and Watson (2007) vary between 584 and $1628^{\circ} \mathrm{C}$, whereby the derived temperatures obviously increase systematically with the amount of zircon-incompatible elements (Fig. 12d). Zircon core and rim analyses of the anhedral zircon grains, all with relatively low contents in $\mathrm{Ca}, \mathrm{Fe}, \mathrm{Sr}$ and LREE, yield temperatures between $584^{\circ} \mathrm{C}$ and $781^{\circ} \mathrm{C}(2 \sigma$ below $16^{\circ} \mathrm{C}$, Ferry \& Watson, 2007), whereas the (sub-)euhedral grains, having all much higher contents in $\mathrm{Ca}, \mathrm{Fe}, \mathrm{Sr}$ and LREE, yield temperatures between 724 and $1628^{\circ} \mathrm{C}(2 \sigma$ below $16^{\circ} \mathrm{C}$, Ferry \& Watson, 2007) (Fig. 12d, Table 5). The highest temperatures (corresponding to the highest $\mathrm{Ti}$ contents) were calculated from domains having the highest $\mathrm{Ca}+\mathrm{Fe}$ contents (as well as $\mathrm{Sr}$ and LREE), comprising both core and rim domains (for explanation see next chapter). Temperatures estimated from cores and rims of the 
(sub-)euhedral two zircon grains cover nearly the entire temperature range obtained from the anhedral and (sub-)euhedral grains. Here, we note that most of the calculated temperatures are probably meaningless in a geological context for three main reasons. First, the investigated rocks contain neither rutile nor quartz, which are both required by the calibration of Ferry and Watson (2007). A reduced silica activity $\left(\mathrm{aSiO}_{2}\right)$ will result in a temperature underestimate, and a reduced rutile activity $\left(\mathrm{aTiO}_{2}\right)$ to temperature overestimate. Second, and even more important, correlation between Ti-in-zircon temperature and $\mathrm{Ca}+\mathrm{Fe}$ suggest, that the analyzed Ti content was not only controlled by the zircon lattice (and associated thermal conditions), but very likely also by interstitial domains (see next chapter), causing an overestimation of the zircon crystallization temperature. Third, the composition of most rims, but also of core domains was modified by coupled dissolution-re-precipitation processes, which perhaps also affected the $\mathrm{Ti}$ contents. Taking these three processes into account, it seems that Ti-in-zircon temperatures obtained from the anhedral grains most likely represent minimum temperatures, and those obtained from the (sub-)euhedral grains maximum temperatures.

\section{STABLE ISOTOPE DATA}

Carbonates from the carbonatite facies of the CAI have $\delta^{13} \mathrm{C}$ values from $-6.1 \%$ to $-6.8 \%$ o and $\delta^{18} \mathrm{O}$ values from +6.7 to $+7.3 \%$ (Fig. 13 , Table 7 ). In the $\delta^{13} \mathrm{C}_{\mathrm{v} \text {-PDB }}$ vs ${ }^{18} \mathrm{O}_{\mathrm{V}-\mathrm{Smow}}$ diagram (Fig. 13), data plot in the primary carbonatite field defined by Taylor et al. (1967).

Both the (sub-)euhedral and anhedral zircon grains show a wide range of $\delta^{18} \mathrm{O}_{\mathrm{V} \text {-smow }}$ values spreading from the supra-mantle to sub-mantle field (mantle signature of $+5.3 \pm 0.3 \%$ as defined by Valley et al., 2005). The (sub-)euhedral and anhedral grains 
have $\delta^{18} \mathrm{O}_{V \text {-SMOW }}$ spreading between +2.9 and $+7.8 \%$, and between +1.3 and $+5.7 \%$ (Fig. 14, Table 6), respectively. The $\delta^{18} \mathrm{O}_{\mathrm{V} \text {-SMow }}$ values both populations are positively correlated to the $\mathrm{Ca}$ and Fe contents (Fig. 14, Table 6).

\section{FIGURE 13}

\section{FIGURE 14}

\section{U-Pb DATING OF ZIRCON AND APATITE}

Twenty-five zircon grains from the carbonate-bearing coarse-grained nepheline syenite have been investigated through 41 spot analyses. Plotted in a concordia diagram, 17 of these analyses above $99 \% \mathrm{~Pb}-\mathrm{Pb}$ conc. define a concordant date of $957.5 \pm 2.9 \mathrm{Ma}$ $\left(M S W D=0.74\right.$, Fig. 15a, Table 5). The degree of concordance of the ${ }^{207} \mathrm{~Pb} /{ }^{206} \mathrm{~Pb}$ apparent ages varies between the two dominant zircon populations as (sub-)euhedral grains show a strong decrease of the degree of concordance with increasing $\mathrm{Ca}$ and Fe contents (Fig. $15 \mathrm{~b})$, and the anhedral grains all show high degrees of concordance with variations that are not linked to the $\mathrm{Ca}$ and Fe contents (Fig. 15b, Table 5). Both populations show a

dominant mode of distribution of their ${ }^{207} \mathrm{~Pb} /{ }^{206} \mathrm{~Pb}$ apparent ages at ca. $957 \mathrm{Ma}$ and a younger one at ca. $850 \mathrm{Ma}$ and ca. $920 \mathrm{Ma}$ for the (sub-)euhedral and anhedral zircon grains (Fig. 15c), respectively.

Fifteen apatite grains from the carbonatite have been investigated through 26 analyses. Due to the generally low radiogenic- $\mathrm{Pb} /$ common- $\mathrm{Pb}$ ratio, data were plotted in a TeraWasserburg diagram (Tera \& Wasserburg, 1972). Data define a discordia yielding a lower intercept date of $934 \pm 25 \mathrm{Ma}$ and an initial ${ }^{206} \mathrm{~Pb} /{ }^{207} \mathrm{~Pb}$ ratio of 0.945 consistent with the model evolution of Stacey \& Kramers (1975) (Fig. 15d). 


\section{FIGURE 15}

\section{DISCUSSION}

\section{Evidence for a silicate-carbonate liquid-immiscibility magmatic process}

The ocelli facies

Ocelli textures, like those described here (Fig. 4a-c), are rare in igneous rocks. Different magmatic processes have been proposed to explain the diversity of ocelli settings and habits (Leveson et al., 1966). Occurrences of ocelli/spherical assemblages that we refer here to as 'ocelli' have been described in alkaline/carbonatitic environment, including carbonatite (Lapin \& Vartiainen, 1983), carbonatitic kimberlite (Haggerty \& Fung, 2006), or ijolite (Zurevinski \& Mitchell, 2015). At Shombole (Kenya-Tanzania), many nephelinite lavas contain globular carbonate-rich segregations, interpreted by Peterson (1989) and further by Kjarsgaard \& Peterson (1991) as the result of a silicate-carbonate liquid immiscibility. Potter et al. (2017) described silicate spheroids within a carbonatite groundmass in the Oldoinyo Lengai 1933 lava, and these authors plead again for liquid immiscibility. This process has also been studied using melt inclusions entrapped in cocrystallising minerals such as nepheline, perovskite, pyroxene and magnetite (Kjarsgaard et al., 1995; Nielsen et al., 1997; Xu et al., 2004; Panina, 2005; Thompson et al., 2007; Guzmics et al., 2011, 2012; Sharygin et al., 2012; Sekisova et al., 2015; Potter et al., 2017; Mollex, 2017; Baudoin et al., 2018). These immiscible melts are proposed to be the parental magmas of nephelinitic silicate rocks, calciocarbonatite (sövite) (Guzmics et al., 2012), and in some examples sulfides (Guzmics et al., 2012; Demaiffe et al., 2013), either formed in plutonic or volcanic environments (Le Bas et al., 1981). 
When plotted in the Freestone \& Hamilton projection (1980), the whole rock composition of the nepheline syenite and silicocarbonatite lithologies of the CAI follow the nepheline-carbonatite melt miscibility gap proposed by Kjarsgaard \& Peterson (1991; solvus at $0.5 \mathrm{GPa}, 1050-900^{\circ} \mathrm{C}$, Fig. 16). The silica-alkali poor composition of the carbonatite does not fit with this experimental miscibility gap. This may be due to the modification of the initial magmatic composition by late-stage magmatic or secondary processes leading to silica-alkali-depleted to -free carbonatite bulk composition. This latter composition, when compared to the geochemistry of carbonatitic melt inclusions and carbonatitic rocks in the same environment, has been interpreted by Guzmics et al. (2012) to be not representative of the initial magmatic composition. To summarize, we propose that the spectacular ocelli facies in the silicocarbonatite likely evidence a silicatecarbonate immiscibility process in the CAI. This would have led to coeval silicate-bearing and carbonate-bearing magmas. The silicate-bearing magmas are represented by preimmiscibility carbonate-bearing coarse-grained nepheline syenite and post-immiscibility carbonate-free pegmatitic facies, whereas the carbonate-bearing magmas are represented by syn-immiscibility ocelli facies and silicocarbonatites, and by postimmiscibility carbonatites (see below).

Field relationships and whole-rock geochemistry

The field relationships and whole-rock geochemistry from rocks of the CAI are consistent with an (i) evolution from a common carbonate-bearing magma of ijolitic composition, the (ii) fractionation of the ijolitic magma into pre-immiscibility carbonate-bearing nepheline syenite and silicocarbonatites, the (iii) formation of the syn-immiscibility ocelli facies that records the segregation of silicate and carbonatitic liquids, and the (iv) post-immiscibility 
emplacement of the carbonate-poor to free dyke swarms of nepheline syenite (pegmatitic together with their feeder conduits) and the calcio- and ferro-carbonatites. Field observations show clear separation of the different rock units with no to few evidence of magma mixing or mingling as shown by the lack of enclaves and crosscutting relationships. This is consistent with the whole-rock geochemistry that highlights two distinct trends starting from an ijolite composition. Together they support the model of immiscibility rather than mixing between a silicate and a carbonatitic liquid.

\section{Pyrochlore geochemistry as a tracer of immiscibility}

Accessory minerals such as pyrochlore or REE-bearing minerals have been used to decipher carbonatite features, e.g. chemical evolution from plutonic to volcanic carbonatites, as well as magmatic to hydrothermal processes (Bambi et al., 2012; McCreath et al., 2012; Torro et al., 2012). However, only few studies used these accessory minerals to document petrogenetic processes such as liquid immiscibility (Taubald et al., 2004; Lee et al., 2006; Morteani et al., 2013; Walter et al., 2018; Giebel et al., 2019).

In the CAI, pyrochlore grains are predominantly associated with nepheline syenite, they display evidence of polyphase growth and they are associated with numerous episodes of dissolution and reprecipitation in the magmatic stage (Fig. 9a). We interpret some of these episodes to be linked to disequilibrium processes between the early crystallized generation of magmatic pyrochlore grains and the evolving magma, leading to the formation of several generations of primary magmatic pyrochlore grains.

It has been suggested that the pyrochlore composition can be linked to the evolution of the chemistry of the melt (Hogarth et al., 2000; Jung Lee et al., 2006; Zaitsev et al., 2012), 
therefore pyrochlore minerals can theoretically be used as a proxy for the geochemical evolution of the melt from which they crystallized. When compared to pyrochlore grains from other complexes, the pyrochlore from the CAl show some distinctive features. Indeed, the two trends observed in Fig. 9b are unusual at the scale of an alkaline complex. Pyrochlore generally follow one trend, the most common one in alkaline and peralkaline complexes being a dominant trend between $\mathrm{Nb}$ and $\mathrm{Ti}$ following the solid solution substitution scheme between pyrochlore and betafite (substitution (2), Chakhmouradian \& Mitchell, 2002; Shrinivas \& Bismayer, 2010; Cordeiro et al., 2011; McCreath et al., 2012). In highly evolved peraluminous rocks, pyrochlore mainly follow a Ta-Nb or a Ta-Ti trend (Ohnenstetter \& Piantone, 1992). The pyrochlore from the ocelli facies of the CAI follow a $\mathrm{Nb}$-Ta differentiation trend, whereas the grains from the younger pegmatitic nepheline syenite dykes follow a Nb-Ti trend (Fig. 9c-d). The ocelli facies (Fig. 4a-c) is characterized by spheres of carbonate-bearing nepheline syenite material separated by a matrix of fluorapatite-bearing carbonatite. The younger pegmatitic nepheline syenite dykes are characterized by a lack of primary magmatic carbonates, less fluorapatite and the pyrochlore grains they contain follow a more "classical" Nb-Ti trend (Fig. 9b). The greater Ta content of pyrochlore from the ocelli facies can be explained by the $\mathrm{Nb} / \mathrm{Ta}$ partitioning behavior in the silicate/carbonate melt, the evolution of the fluorine fugacity ( $F$ fugacity) and the metal content of the melt. The $K_{D} \mathrm{Nb} / \mathrm{Ta}$ carb-sil at 0.8-0.9 kbar and temperature ranging from 965 to $1015^{\circ} \mathrm{C}$ is $\sim 5.1$ (Veksler et al., 1998a), indicating that these two elements can be strongly fractionated by an immiscibility process between a silicate and a carbonatitic liquid. Tantalum is likely to be incorporated into the silicate liquid, whereas $\mathrm{Nb}$ will more strongly partition into the carbonate liquid. Therefore, 
immiscibility between carbonate and silicate liquids would lead to the formation of a Ta"supersaturated" silicate melt.

Zheng et al. (2014) proposed that the concentration of Ta in pyrochlore could also be controlled by the $\mathrm{F}$ fugacity of the melt. The pyrochlore grains are closely associated with fluorapatite, and F and Ta contents are negatively correlated within pyrochlore grains (Table 3). The ocelli facies of the CAI is characterized by the presence of fluorapatite aggregates within the carbonatitic matrix. The crystallization of fluorapatite could lead to a decrease of the $\mathrm{F}$ fugacity of the melt. Accordingly, the combined action of segregation of a carbonate liquid from a silicate parental melt, and the decrease of the $F$ fugacity would lead to the crystallization of an early generation of Ta-bearing pyrochlore that would subsequently result in a decrease of the available Ta content in the melt. After complete separation of the silicate and carbonatitic liquids, the fractionation between $\mathrm{Nb}$ and $\mathrm{Ta}$

most probably stopped, thus leading to the crystallization of $\mathrm{Nb}$-rich pyrochlore in the pegmatitic nepheline syenite dykes with more constant $\mathrm{Nb} / \mathrm{Ta}$ ratios and a more classic $\mathrm{Nb}-\mathrm{Ti}$ solid solution trend (Fig. 9e).

To sum up, we propose that the two magmatic populations of pyrochlore observed within the nepheline-bearing rocks of the CAI result from the immiscibility between a carbonate and a silicate melt.

\section{Petrogenetic model for syenite-carbonatite immiscibility}

Using the petrological, geochemical, and geochronological constraints obtained on the CAI (field and petrographic data, whole rock geochemical data, characteristics of accessory minerals that are zircon, pyrochlore and apatite), we propose a petrogenetic model of magmatic evolution for the CAl (Fig. 17). 
Stage 1. Emplacement of a mantle-derived ijolitic/urtitic magma

We propose that the ijolite/urtite magma emplaced within a medium to low pressure allochthonous crustal segment of the Grenville Province represents the initial melt of the CAI. Indeed, in spider, Harker and A-B diagrams, the ijolite/urtite composition always plots at the intersection between the silicate and carbonatitic trends (Figs. 5-7, Table 2). This rock is characterized by a nepheline + alkali feldspar + phlogopite + aegirine + apatite + calcite ( \pm Fe-Ti oxides) assemblage (Fig. 17).

Stage 2. Fractionation of the initial melt and formation of nepheline syenite \pm carbonates The ijolitic/urtitic magma experienced fractionation that led to the formation of the coarsegrained carbonate-bearing nepheline syenite that constitutes the main unit of the CAI. The observed crosscutting field relationships between the different units (Figs. 2-3) indicate that the coarse-grained carbonate-bearing nepheline syenite was emplaced before the pegmatitic nepheline syenite, the ocelli facies, the silicocarbonatites and the other carbonatites. In the carbonate-bearing nepheline syenite, the (sub-)euhedral zircon population is composed of zircon grains with high and positively correlated $\mathrm{Ca}, \mathrm{Fe}, \mathrm{LREE}$ (mainly La), Sr and Ti contents (Fig. 12b-d, Table 5). Such large ionic radii/low ionic charge trace element does not fit into the zircon lattice; therefore, their high contents are usually related to alteration processes (e.g. Geisler et al., 2001, 2007; Hanchar et al., 2001; Hoskin \& Schaltegger, 2003; Zeh et al., 2014). However, it could also result from the entrapment of co-precipitated nano-inclusions into the zircon lattice during zircon growth as proposed by Turlin et al. (2019). This process might have been similar to one recently described by Zeh et al. (2018) to explain relatively high Th and REE contents in 
authigenic rutile. The striking correlation between $\mathrm{Ti}$ and $\mathrm{Ca}+\mathrm{Fe}(\mathrm{REE}, \mathrm{Sr})$ might point to co-precipitation of phases like perovskite $\left(\mathrm{CaTiO}_{3}\right)$, even though pure perovskite can be excluded, as the amount of $\mathrm{Ca}+\mathrm{Fe}$ commonly exceed the $\mathrm{Ti}$ amount by a factor 10 or more. Co-precipitation of nano-phases can also account for the observation that high amounts of $\mathrm{Ca}, \mathrm{Fe}, \mathrm{LREE}, \mathrm{Sr}$, and $\mathrm{Ti}$ were not only analyzed on zircon rims of the (sub)euhedral zircon grains, modified by a coupled dissolution-re-precipitation processes, but also on zircon cores still showing an oscillatory zoning (see Fig. 10). On the other hand, low contents in $\mathrm{Ca}$, Fe, LREE, Sr of the anhedral zircon grains suggest zircon growth without co-precipitation and/or entrapment of any Ca-Fe-Ti-rich nanophase.

The finding of both zircon generations, with and without high Ca-Fe-LREE-Sr contents, as well as of intermediate zircon (see Fig. 12) within the same rock sample suggest that the melt environment changed significantly during zircon growth, allowing the entrapment of Ca-Fe-Ti-rich nanophases during an early stage of zircon growth, but not during a later stage. We interpret the (sub-)euhedral population to be the first zircon generation to crystallize in a carbonate-saturated liquid, followed by the intermediate zircon generation. This interpretation is in agreement with the commonly supra-mantle $\delta^{18} \mathrm{O}_{\mathrm{V} \text {-smow }}$ values obtained from pristine cores of the (sub-)euhedral population, ranging between the mantle value of $+5.3 \pm 0.3 \%$ (Valley, 2005) and $+7.8 \%$, in agreement with syenite-carbonatite melt extraction from an enriched mantle source (Marks \& Markl, 2017 and references therein). The sub-mantle values down to $+2.9 \%$ (Fig. 15), might result from alteration of the primary zircon grains by a coupled dissolution-re-precipitation process after growth of the (sub)euhedral grains, in order to minimize the lattice stain caused by the incorporation of the abundant zircon-incompatible trace elements. 
The anhedral zircon grains perhaps formed later in the syenite magma, after abundant extraction of carbonate-rich fluid from the initially mixed melt. This unmixing would not only prevent the co-precipitation of Ca-Fe-Ti-rich phases during zircon growth, but would also cause the fractionation of $\delta^{18} \mathrm{O}_{\mathrm{V} \text {-smow }}$ between the carbonate-rich and silica-rich melt phase, responsible for the generally lower $\delta^{18} \mathrm{O}_{V \text {-SMow }}$ of the anhedral zircon grains $(+1.3$ to $+5.7 \%$ ) compared to the (sub)euhedral grains $(+2.9$ to $+7.8 \%$; Fig. 14 , Table 6$)$; although post-growth alteration of the anhedral zircon grains cannot be excluded.

Stage 3. Immiscibility between carbonatitic and silicate liquids

This stage corresponds to the silicate-carbonate liquid immiscibility process, i.e. to the physical separation of both liquids. The main arguments in favor of this specific immiscibility stage are: (i) the presence of coalescent nepheline syenite droplets/spheres in a carbonatitic matrix (ocelli facies; Fig. 4a-c), (ii) emplacement of silicocarbonatites and the ocelli facies with Ta-enriched pyrochlore grains, (iii) different $\delta^{18} \mathrm{O}_{V \text {-smow }}$ of (sub)euhedral and anhedral zircon, and finally (iv) dissolution/reprecipitation rim textures mainly around the (sub-)euhedral zircons (Figs. 10a, 11a, 17).

\section{Stage 4. Post-immiscibility conditions}

Following their complete separation, the silicate and carbonatitic liquids continued to evolve individually during a post-immiscibility stage. Pyrochlore grains associated with this stage within the pegmatitic nepheline syenite follow a $\mathrm{Nb}$ - Ti solid solution and are characterized by higher $\mathrm{Nb} / \mathrm{Ta}$ ratios (Tables 3 and $\mathrm{S} 1$ ). The anhedral zircon grains of the coarse-grained nepheline syenite show low $\mathrm{Ca}, \mathrm{Fe}, \mathrm{LREE}, \mathrm{Sr}$ and Ti contents, similar to 
the ones of the rims in the intermediate zircon grains (Fig. 12b-d, Table 5). These features support crystallization of anhedral zircon in a carbonate-poor silicate liquid, i.e. postimmiscibility. In addition, except for one analysis that falls within the mantle domain $\left(\delta^{18} \mathrm{O}_{V}\right.$ smow values of $+5.8 \pm 0.6 \%$ ), all $\delta^{18} \mathrm{O}_{\mathrm{V} \text {-smow }}$ values of these zircon grains are in the submantle domain, with values between $+1.3 \pm 0.4$ and $+5.1 \pm 0.5 \%$ (Fig. 14, Table 5). They indicate a crystallization in equilibrium with the carbonatites. Indeed, at $500-800^{\circ} \mathrm{C}$, using the isotopic fractionation factor of Zheng (1993), zircon in equilibrium with carbonatites would have $\delta^{18} \mathrm{O}_{\mathrm{V} \text {-smow }}$ values lower by 2.5 to $4.5 \%$ than the $\delta^{18} \mathrm{O}_{\mathrm{V} \text {-smow }}$ values of the carbonatites that is of +6.7 to $+7.3 \%$ (Fig. 4 , Tables 5 and 7 ), namely values between $+2.2 \%$ and $+4.8 \%$, close to the range actually measured.

In-situ LA-ICP-MS U-Pb dating of zircon and apatite constrain the timing of emplacement of the nepheline syenite at $957.5 \pm 2.9 \mathrm{Ma}$ (Fig. 15a) and of the carbonatite at $934 \pm 25 \mathrm{Ma}(15 \mathrm{~d})$, respectively.

\section{The Crevier alkaline intrusion in the late-Grenvillian tectonic frame: implications for the formation of rare metal deposits in late- to post-collisional settings}

The late stages of the Grenvillian Orogeny (ca. 980-950 Ma) are marked by the thermal relaxation of the continental crust following gravitational spreading and weakening of the convergence that led to orogenic collapse and thinning of the crust associated with low cooling rates of ca. $2-6^{\circ} \mathrm{C} / \mathrm{Ma}$ (Turlin et al., 2018). This is witnessed in the medium to low pressure crustal segment of the Allochthonous Belt (aM-LP, Fig. 1b) by the apatite diffusion modeling that yielded a closure temperature of apatite crystals of $550-450^{\circ} \mathrm{C}$ at ca. $960 \mathrm{Ma}$ (Turlin et al., 2018). Two mechanisms have been proposed to account for this 
thermal evolution, a slab retreat (Turlin et al., 2018) or a lithospheric foundering (also referred to delamination; Corrigan \& Hanmer, 1997; Groulier et al., 2018b) of the subcontinental lithospheric mantle. This late evolution of the Grenvillian Belt is associated with small volumes of late- to post-tectonic mantle-derived within-plate silica-saturated (sometimes fluorine-bearing) or silica-undersaturated alkaline magmas.

In the central Grenville Province, this event is characterized by the intrusion of syenitic bodies of the undersaturated $\mathrm{CAl}$ at ca. $960-955 \mathrm{Ma}$ (U-Pb on zircon, this contribution). It is composed of nepheline syenite and carbonatitic rocks consistent with low-degree of partial melting of a volatile-rich mantle source (Le Bas, 1987; Gittins, 1989; Bailey, 1993; Winter, 2001; Mitchell, 2005; Millong \& Groat, 2013). Such mantle enrichment is expected after the extensive metasomatism of the Grenvillian subcontinental lithospheric mantle during the Proterozoic as the southeastern Laurentian margin was an active margin over a period of 500 Ma (Rivers \& Corrigan, 2000; Corriveau \& Morin, 2000; Whitmeyer \& Karlstrom, 2007; Rivers et al., 2012; Groulier et al., 2018b). The shape of the CAl indicates a strong structural control following the general orientation of a major crustal lineament known as the Waswanipi-Saguenay corridor (Bernier \& Moorhead, 2000). This major crustal lineament is characterized by the presence of the Paleoproterozoic Nb-REEbearing Montviel carbonatitic complex (David et al., 2006) and by the Neoproterozoic Nbbearing Saint-Honoré carbonatite (Tremblay et al., 2015). The presence of three major $\mathrm{Nb}( \pm \mathrm{Ta}$ in the $\mathrm{CAl})$ deposits along this lineament highlights the importance of two crucial factors for the formation of such deposits: (i) a fertile and enriched subcontinental lithospheric mantle source able to produce carbonatitic and undersaturated magma, and (ii) a crustal weakness to facilitate the ascent and emplacement of the $\mathrm{Nb}( \pm \mathrm{Ta})$-bearing 
magma within the crust during extensional tectonic setting (late/post-tectonic to anorogenic).

Accordingly, the ca. $980-950$ Ma late- to post-Grenvillian period is prospective for the formation of $\mathrm{Nb}( \pm \mathrm{Ta})$-bearing magmas as it is characterized by discrete and low-degree partial melting of the mantle in an overall extensional tectonic setting.

\section{CONCLUSION}

Petrogenetic relationships between different undersaturated alkaline igneous rocks, carbonate-bearing and carbonate-free nepheline syenite and carbonatites observed in the Crevier Alkaline Intrusion (CAI) are proposed to result from the immiscibility between a carbonate and a silicate melt. The spectacular ocelli facies observed in the pegmatitic nepheline syenite dyke swarms is considered to evidence the syn-immiscibility stage, whereas the carbonate-free nepheline syenite and the calcio- and ferro-carbonatites are considered to be post-immiscibility. Accessory minerals (pyrochlore, zircon, and apatite) record geochemical and isotopic features that (i) argue for this immiscibility process, and (ii) allow to constrain the thermal conditions of immiscibility at a minimum temperature of $\sim 815-865^{\circ} \mathrm{C}$ and its timing ( $\mathrm{U}-\mathrm{Pb}$ on zircon of the nepheline syenite at $957.5 \pm 2.9 \mathrm{Ma}$, and on apatite of the carbonatite at $934 \pm 25 \mathrm{Ma}$ ). Two generations of pyrochlore have been described: (i) a syn-immiscibility Ta-U-Ca-enriched type, and (ii) a post-immiscibility $\mathrm{Nb}-\mathrm{Ti}$-Th-Na-enriched type. We propose that the behavior of $\mathrm{Nb}$ and $\mathrm{Ta}$ is strongly connected to the immiscibility process and to the F-fugacity of the melt. This ca. 980-950 Ma late- to post-Grenvillian period is prospective for the formation of $\mathrm{Nb}( \pm \mathrm{Ta})$-bearing magmas as it is characterized by discrete and low-degree partial melting of the mantle in an overall extensional tectonic setting. 


\section{ACKNOWLEDGMENTS}

This publication is issued from the MsC thesis of Pierre-Arthur Groulier (2013) and Alexandre Crépon (2017). The authors would like to thank the Ministère de l'Énergie et des Ressources naturelles (Québec) for providing technical and financial support for the field work and analyses. MDN is thanked for providing access to their Crevier property, as well as drill cores. This contribution represents the Ministère de l'Énergie et des Ressources naturelles du Québec publication n8449-2017-2018-11. The authors are also grateful to Sandrine Mathieu (SEM), Lise Salsi (SEM), Andreï Lecomte (SEM) and Olivier Rouer (EMP) (GeoRessources, Nancy) for technical support in providing analytical data on SEM and EPMA. The Master internship of Alexandre Crépon was financed by the LabEx RESSOURCES21 (supported by the French National Research Agency through the national program "Investissements d'avenir", reference ANR-10-LABX-21-LABEX RESSOURCES 21), and benefited of the framework of the DIVEX "Rare earth element" research program. The authors also thank Anouk Borst and two anonymous reviewers for their constructive reviews, as well as Tod Waight and Marjorie Wilson for editorial handling. 


\section{References}

Atencio, D., Andrade, M.B, Christy, A.G., Giere, R. \& Kartashov, P.M. (2010). The pyrochlore supergroup of minerals: nomenclature. The Canadian Mineralogist 48, 673-698.

Bailey, D.K. (1993). Carbonate magmas. Journal of the Geological Society, London 150, 637-651.

Bambi, A.C.J.M., Costanzo, A., Goncalves, A.O. \& Melgarejo, J.C. (2012). Tracing the chemical evolution of primary pyrochlore from plutonic to volcanic carbonatites: the role of fluorine. Mineralogical Magazine 76, 377-392.

Baudouin, C., Parat, F. \& Michel, T. (2018). $\mathrm{CO}_{2}$-rich silicate melt and carbonatite immiscibility in early stage rifting: melt inclusions from Hanang volcano. Journal of Volcanology and Geothermal Research 358, 261-272.

Bédard, P.L., \& Chown H. (1992). The Dolodau Dykes, Canada: an example of an Archean Carbonatite. Mineralogy and Petrology 46,109-121.

Bell, K. (1998). Radiogenic isotope constraints on relationships between carbonatites and associated silicate rocks-a brief review. Journal of Petrology 39, 1987-1996.

Bell, K. \& Blenkinsop, J. (1989). Carbonatites: genesis and evolution. Unwin Hyman, London.

Bell, K., Kjarsgaard, B. A. \& Simonetti, A. (1998). Carbonatites-into the twenty-first century. Journal of Petrology 39, 1839-1845.

Bell, K. \& Simonetti, A. (2010). Source of parental melts to carbonatites-critical isotopic constraints. Mineralogy and Petrology 98:77-89.

Belousova, E.A., Walters, S., Griffin, W.L. \& O'Reilly, S.Y. (2001). Trace element signatures of apatites from granitoids of Mount Isa Inlier, north-west Queensland, Australia. Australian Journal of Earth Sciences 48, 603-619.

Belousova, E.A., Griffin, W.L., O'Reilly, S.Y. \& Fisher, N.I. (2002). Apatite as an indicator mineral for mineral exploration: trace-element compositions and their relationship to host rock type. Journal of Geochemical Exploration 76, 45-69.

Bergeron, A. (1980). Pétrographie et géochimie du complexe igné alcalin de Crevier et de son encaissant métasomatisé (Unpublished MSc thesis). Université du Québec à Chicoutimi, Chicoutimi, $142 \mathrm{p}$.

Bernier, L. \& Moorhead, J. (2000). Contrôles structuraux, caractéristiques pétrographiques et minéralogiques de la kimberlite d'Otish. Ministère des Ressources Naturelles, Québec, 55 $\mathrm{pp}$.

Bickford, M.E., Van Schmus, W.R., Karlstrom, K.E., Mueller, P.A., \& Kamenov, G.D. (2015). Mesoproterozoic-trans-Laurentian magmatism: A synthesis of continent-wide age 
distributions, new SIMS U-Pb ages, zircon saturation temperatures, and $\mathrm{Hf}$ and $\mathrm{Nd}$ isotopic compositions. Precambrian Research 265, 286-312.

Bourne, J. (1991). The geochemistry of the La Galissonnière Pluton: a Middle Proterozoic lateorogenic intrusion from the eastern Grenville Province, Quebec. Canadian Journal of Earth Sciences 28, 37-43.

Bouzari, F., Hart, C.J.R., Bissig, T. \& Barker, S. (2011). Hydrothermal Alteration Revealed by Apatite Luminescence and Chemistry: A Potential Indicator Mineral for Exploring Covered Porphyry Copper Deposits. Economic Geology 111, 1397-1410.

Brey, G. P., Bulatov, V. K., Girnis, A. V. \& Lahaye, Y. (2008). Experimental melting of carbonated peridotite at $610 \mathrm{GPa}$. Journalof Petrology 49, 797-821.

Brooker, R. (1998). The effect of $\mathrm{CO}_{2}$ saturation on immiscibility between silicate and carbonate liquids: an experimental study. Journal of Petrology 39, 1905-1915.

Brooker, R.A. \& Kjarsgaard, B.A. (2011). Silicate-carbonate liquid immiscibility and phase relations in the system $\mathrm{SiO}_{2}-\mathrm{Na}_{2} \mathrm{O}-\mathrm{Al}_{2} \mathrm{O}_{3}-\mathrm{CaO}-\mathrm{CO}_{2}$ at 0.1-2.5 $\mathrm{GPa}$ with applications to carbonatite genesis. Journal of Petrology 52, 1281-1305.

Bühn, B., Wall, F. \& Le Bas, M.J. (2001). Rare-earth element systematics of carbonatitic fluorapatites, and their significance for carbonatite magma evolution. Contributions to Mineralogy and Petrology 141, 572-591.

Cao, M., Li, G., Qin, K., Seitmuratova, E.Y. \& Liu, Y. (2012). Major and trace element characteristics of apatite in granitoids from central Kazakhstan: Implications for petrogenesis and mineralization. Resource Geology 62, 63-83.

Carrapa, B., DeCelles, P.G., Reiners, P.W., Gehrels, G.E., \& Sudo, M. (2009). Apatite triple dating and white mica ${ }^{40} \mathrm{Ar} /{ }^{39} \mathrm{Ar}$ thermochronology of syntectonic detritus in the Central Andes: multiphase tectonothermal history. Geology 37, 407-410.

Chakhmouradian, A.R. \& Mitchell, R.H. (2002). New data on pyrochlore-and perovskite-group minerals from the Lovozero alkaline complex, Russia. European Journal of Mineralogy 14, 821-836.

Chakhmouradian, A.R., Reguir, E.P., Kressall, R.D., Crozier, J., Pisiak, L.K., Sidhu, R. \& Yang, P. (2015). Carbonatite-hosted niobium deposit at Aley, northern British Columbia (Canada): Mineralogy, geochemistry and petrogenesis. Ore Geology Reviews 64, 642-666.

Chakhmouradian, A.R., Reguir, E.P., Zaitsev, A.N., Couëslan, C., Xu, Cheng, Kynický, J., Mumin, A.H. \& Yang, P. (2017). Apatite in carbonatitic rocks: Compositional variation, zoning, element partitioning and petrogenetic significance. Lithos 274-275, 188-213. 
Chamberlain, K.R. \& Bowring, S.A. (2001). Apatite-feldspar U-Pb thermochronometer: a reliable, mid-range $\left(\sim 450^{\circ} \mathrm{C}\right)$, diffusion-controlled system. Chemical Geology 172, 173-200.

Cherniak, D.J. \& Watson, E.B. (2001). Pb diffusion in zircon. Chemical Geology 172, 5-24.

Cherniak, D.J., Lanford, W.A., \& Ryerson, F.J. (1991). Lead diffusion in apatite and zircon using ion implantation and Rutherford backscattering techniques. Geochimica et Cosmochimica Acta 55, 1663-1673.

Chew, D.M., Sylvester, P.J. \& Tubrett, M.N. (2011). U-Pb and Th-Pb dating of apatite by LAICPMS. Chemical Geology 280, 200-216.

Chew, D.M., Petrus, J.A. \& Kamber, B.S. (2014). U-Pb LA-ICPMS dating using accessory mineral standards with variable common Pb. Chemical Geology 363, 185-199.

Church, A.A. \& Jones, A.P. (1995). Silicate-carbonate immiscibility at Oldoinyo Lengai. Journal of Petrology. 36, 869-889.

Clarke, L.B., Le Bas, M.J. \& Spiro, B. (1993). Rare Earth, trace elements and stable isotope fractionation of carbonatites at Kruidfontein, Transvaal, South Africa. Proceedings of the Fifth Kimberlite Conference, 1, Kimberlite, related rocks and mantle xenoliths. CPRM, Brasilia, 236-51.

Cochrane, R., Spikings, R.A., Chew, D., Wotzlaw, J.-F., Chiaradia, M., Tyrrell, S., Schaltegger, U. \& Van der Lelij, R. (2014). High temperature $\left(>350^{\circ} \mathrm{C}\right)$ thermochronology and mechanisms of $\mathrm{Pb}$ loss in apatite. Geochimica et Cosmochimica Acta 127, 39-56.

Cordeiro, P.F.O., Brod, J.A., Palmieri, M., de Oliveira, C.G., Barbosa, E.S.R., Santos, R.V., Gaspar, J.C. \& Assis, L.C. (2011). The Catalão niobium deposit, central Brazil: resources, geology and pyrochlore chemistry. Ore Geology Reviews 41, 112-121.

Corriveau, L. \& Morin, D. (2000). Modelling 3D architecture of western Grenville from surface geology, xenoliths, styles of magma emplacement, and Lithoprobe reflectors. Canadian Journal of Earth Sciences 37, 235-251.

Dalton, J. A. \& Wood, B. J. (1993). The compositions of primary carbonate melts and their evolution through wallrock reaction in the mantle. Earth and Planetary Science Letters 119, 511-525.

Dalton, J. A. \& Presnall, D. C. (1998). The continuum of primary carbonatitic-kimberlititc melt compositions in equilibrium with Iherzolite: data from the system $\mathrm{CaO}-\mathrm{MgO}-\mathrm{Al}_{2} \mathrm{O}_{3}-\mathrm{SiO}_{2}-$ $\mathrm{CO}_{2}$ at $6 \mathrm{GPa}$. Journal of Petrology 39, 1953-1964.

Dasgupta, R., Hirschmann, M. M., McDonough, W. F., Spiegelman, M. \& Withers, A. C. (2009). Trace element partitioning between garnet lherzolite and carbonatite at 6.6 and $8.6 \mathrm{GPa}$ 
with applications to the geochemistry of the mantle and of mantle-derived melts. Chemical Geology 262, 57-77.

David, J., Dion, C., Goutier, J., Roy, P., Bandyayera, D., Legault, M. \& Rhéaume, P. (2006). Datations U-Pb effectuées dans la Sous-province de l'Abitibi à la suite des travaux de 2004-2005. Ministère des Ressources Naturelles du Québec, Rapport RP2006-04.

Dawson, J. B., Pinkerton, H., Pyle, D. M. \& Nyamweru, C. (1994). June 1993 eruption of Oldoinyo Lengai, Tanzania: Exceptionally viscous and large carbonatite lava flows and evidence for coexisting silicate and carbonate magmas. Geology 22, 769-864.

Debon, F. \& Le Fort, P. (1988). A cationic classification of common plutonic rocks and their magmatic associations: principles, method, applications. Bull. Minéral. 111, 493-510.

Decrée, S., Boulvais, P., Tack, L., André, L. \& Baele, J.-M. (2015). Fluorapatite in carbonatiterelated phosphate deposits: the case of the Matongo carbonatite (Burundi). Mineralium Deposita 51, 453-466.

Deines, P. (1989). Stable isotope variations in carbonatites. In: Bell, K. (Ed.), Carbonatites: Genesis and Evolution. Unwin Hyman, Boston, 301-350.

Demaiffe, D., Wiszniewska, J., Kreminska, E., Williams, I.S., Stein, H., Brassinnes, S., Ohnenstetter, D. \& Deloule, E. (2013). A hidden alkaline and carbonatite Province of Early Carboniferous age in northeast Poland: Zircon U-Pb and pyrrhotite Re-Os geochronology. The Journal of Geology 121, 91-104.

Demény, A., Ahijado, A., Casillas, R. \& Vennemann, T.W. (1998). Crustal contamination and fluid/rock interaction in the carbonatites of Fuerteventura (Canary Islands, Spain): a C, O, $\mathrm{H}$ isotope study. Lithos 44, 101-115.

Duplessis, C. \& Girard, R. (2010). Technical Report Niobium and Tantalum resource estimation update of the Crevier deposit North of Lac St-Jean Quebec Canada. NI 43-101.

Dunning, G. \& Indares, A. (2010). New insights on the 1.7-1.0 Ga crustal evolution of the central Grenville Province from the Manicouagan - Baie Comeau transect. Precambrian Research 180, 204-226.

Ferry, J.M. \& Watson, E.B. (2007). New thermodynamic models and revised calibrations for the Ti-in-zircon and Zr-in-rutile thermometers. Contributions to Mineralogy and Petrology 154, 429-437.

Freestone, I. C. \& Hamilton, D. L. (1980). The role of liquid immiscibility in the genesis of carbonatites-an experimental study. Contributions to Mineralogy and Petrology 73, 105117. 
Geisler, T., Schaltegger, U. \& Tomaschek, F. (2007). Re-equilibration of Zircon in Aqueous Fluids and Melts. Elements 3, 43-50. doi:10.2113/gselements.3.1.43

Geisler, T., Ulonska, M., Schleicher, H., Pidgeon, R.T. \& van Bronswijk W. (2001). Leaching and differential recrystallization of metamict zircon under experimental hydrothermal conditions. Contrib Mineral Petrol 141, 53-65.

Gerdes, A. \& Zeh, A. (2006). Combined U-Pb and Hf isotope LA-(MC-)ICP-MS analyses of detrital zircons: Comparison with SHRIMP and new constraints for the provenance and age of an Armorican metasediment in Central Germany. Earth and Planetary Science Letters 249, 47-61.

Gerdes, A. \& Zeh, A. (2009). Zircon formation versus zircon alteration - New insights from combined $\mathrm{U}-\mathrm{Pb}$ and Lu-Hf in-situ LA-ICP-MS analyses, and consequences for the interpretation of Archean zircon from the Central Zone of the Limpopo Belt. Chemical Geology 261, 230-243.

Giebel, R.J., Marks, M.A.W., Gauert, C.D.K. \& Markl, G. (2019). A model for the formation of carbonatite-phoscorite assemblages based on the compositional variations of mica and apatite from the Palabora Carbonatite Complex, South Africa. Lithos 324-325, 89-104.

Gittins, J. (1989). The origin and evolution of carbonatite magmas. In: Bell, K. (ed.) Carbonatites: Genesis and Evolution. London: Unwin Hyman, 580-600.

Goutier, J. (2006). Géologie de la région du Lac au goéland (32F15). Ministère des Ressources Naturelles et de la Faune, Québec, RG 2005-05, 39 pp.

Gower, C. F. \& Krogh, T. E. (2002). A U-Pb geochronological review of the Proterozoic history of the eastern Grenville Province. Canadian Journal of Earth Sciences 39, 795-829.

Gower, C. F., Heaman, L. M., Loveridge, W. D., Schärer, U. \& Tucker, R. D. (1991). Grenvillian magmatism in the eastern Grenville Province, Canada. Precambrian Research 51, 315336.

Gower, C. F., Kamo, S. \& Krogh, T. E. (2008). Indentor tectonism in the eastern Grenville Province. Precambrian Research 167, 201-212.

Gower, C. F. \& Krogh, T. E. (2002). A U-Pb geochronological review of the Proterozoic history of the eastern Grenville Province. Canadian Journal of Earth Sciences 39, 795-829.

Griffin, W.L., Powell, W.J., Pearson, N.J., \& O'Reilly, S.Y. (2008). GLITTER: data reduction software for laser ablation ICP-MS. In: Sylvester, P. (ed.) Laser Ablation ICP-MS in the Earth Sciences: Current Practices and Outstanding Issues. Mineralogical Association of Canada, Short Course Series 40, 307-311. 
Groulier, P.A., Ohnenstetter, D., André-Mayer, A.S., Zeh, A., Solgadi, F., Moukhsil, A., \& El Basbas, A. (2014) Étude des minéralisations en Nb-Ta de l'intrusion alcaline de Crevier. Energie et Ressources Naturelles du Québec MB 2014-33, 68p.

Groulier, P.-A., Indares, A., Dunning, G., Moukhsil, A., \& Wälle, M. (2018a). Peri-Laurentian, Pinwarian-age oceanic arc crust preserved in the Grenville Province: Insights from the Escoumins supracrustal belt. Precambrian Research 311, 37-64.

Groulier, P.-A., Indares, A., Dunning, G., Moukhsil, A., Moukhsil, A., \& Jenner, G. (2018b). Synorogenic magmatism over 100 m.y. in high crustal levels of the central Grenville Province: Characteristics, age and tectonic significance. Lithos 312-313, 128-152.

Guzmics, T., Zajacz, Z., Kodolanyi, J., Werner, H. \& Szabo, C. (2008). LA-ICP-MS study of apatiteand K-feldspar-hosted primary carbonatite melt inclusions in clinopyroxenite xenoliths from lamprophyres, Hungary: implication for significance of carbonatite melts in the Earth's mantle. Geochimica and Cosmochimica Acta 72, 1864-1886.

Guzmics, T., Mitchell, R.H., Szabó, C., Berkesi, M., Milke, R. \& Abart, R. (2011). Carbonatite melt inclusions in coexisting magnetite, apatite and monticellite in Kerimasi calciocarbonatite, Tanzania: melt evolution and petrogenesis. Contributions to Mineralogy and Petrology 161, 177-196.

Guzmics, T., Mitchell, R.H., Szabó, C., Berkesi, M., Milke, R. \& Ratter, K. (2012). Liquid immiscibility between silicate, carbonate and sulfide melts in melt inclusions hosted in coprecipitated minerals from Kerimasi volcano (Tanzania): evolution of carbonated nephelinitic magma. Contributions to Mineralogy and Petrology 164, 101-122.

Halama R., Vennemann T., Siebel W. \& Markl G. (2005). The Grønnedal-lka Carbonatite-Syenite Complex, South Greenland: Carbonatite Formation by Liquid Immiscibility. Journal of Petrology 46, 191-217.

Hammouda, T., Moine, B. N., Devidal, J. L. \& Vincent, C. (2009). Trace element partitioning during partial melting of carbonated eclogites. Physics of the Earth and Planetary Interiors 174, 60-69.

Hanchar, J.M., Finch, R.J., Hoskin, P.W.O., Watson, E.B., Cherniak, D.J. \& Mariano, A.N. (2001). Rare earth elements in synthetic zircon: Part 1. Synthesis, and rare earth element and phosphorus doping. American Mineralogist 86, 667-680.

Harmer, R. E. (1999). The petrogenetic association of carbonatite and alkaline magmatism: constraints from the Spitskop Complex, South Africa. Journal of Petrology 40, 525-548.

Harmer, R. E. \& Gittins, J. (1998). The case for primary, mantle-derived carbonatite magma. Journal of Petrology 39, 1895-1903. 
Harrison, R. (1981). Geochronology, petrography and geochemistry of a section of the Crevier alkaline igneous complex (Unpublished Bachelor's thesis). Laval University, 111p.

Harrison, T.M., Catlos, E.J. \& Montel, J.-M. (2002). U-Th-Pb dating of phosphate minerals. Reviews in Mineralogy and Geochemistry 48, 524-558.

Haynes, E.A., Moechera, D.P. \& Spicuzza, M.J. (2003). Oxygen isotope composition of carbonates, silicates, and oxides in selected carbonatites: constraints on crystallization temperatures of carbonatite magmas. Chemical Geology 193, 43-57.

Hiess, J., Bennett, V.C., Nutman, A.P. \& Williams, I.S. (2011). Archaean fluid-assisted crustal cannibalism recorded by low $\delta^{18} \mathrm{O}$ and negative $\varepsilon \mathrm{Hf}(\mathrm{T})$ isotopic signatures of West Greenland granite zircon. Contrib Mineral Petrol 161, 1027-1050.

Hoffman, P.F. (1989). Precambrian geology and tectonic history of North America. In: Bally, A.W., Palmer, A.R. (eds.), The Geology of North America - An Overview. Geological Society of America, Boulder, CO, 447-512.

Hogarth, D.D. (1977). The pyrochlore group. American Mineralogist, 62, 430-410.

Hogarth, D.D., Hartree, R., Loop, J. \& Solberg, T.N. (1985). Rare-earth element minerals in four carbonatites near Gatineau, Quebec. American Mineralogist 70, 1135-1142.

Hogarth, D.D., Williams, C.T. \& Jones, P. (2000). Primary zoning in pyrochlore group minerals from carbonatites. Mineralogical Magazine 64, 683-697.

Hoskin, P.W.O. \& Schaltegger, U. (2003). The Composition of Zircon and Igneous and Metamorphic Petrogenesis. In: Hanchar, J.M. \& Hoskins, P.W.O. (eds.) Zircon, Reviews in Mineralogy and Geochemistry 53. Mineralogical Society of America, 27-62.

Hughes, J.M. \& Rakovan, J. (2002). The crystal structure of apatite, $\mathrm{Ca}_{5}\left(\mathrm{PO}_{4}\right)_{3}(\mathrm{~F}, \mathrm{OH}, \mathrm{Cl})$. Reviews in Mineralogy and Geochemistry 48, 1-12.

Jordan, S.L., Indares, A. \& Dunning, G. (2006). Partial melting of metapelites in the Gagnon terrane below the high-pressure belt in the Manicouagan area (Grenville Province): pressure-temperature (P-T) and U-Pb age constraints and implications. Canadian Journal of Earth Sciences 43, 1309-1329.

Jung Lee, M., Lee, J.I., Garcia, D., Moutte, J., Williams, T., Wall, F. \& Kim, Y. (2006). Pyrochlore chemistry from the Sokli phoscorite-carbonatite complex, Finland: Implications for the genesis of phoscorite and carbonatite association. Geochemical Journal 40, 1-13.

Kjarsgaard, B. A. (1998). Phase relations of a carbonated high-CaO nephelinite at 0.2 and 0.5 GPa. Journal of Petrology 39, 2061-2075.

Kjarsgaard, B. A. \& Hamilton, D. L. (1988). Liquid immiscibility and the origin of alkali-poor carbonatites. Mineralogical Magazine 52, 43-55. 
Kjarsgaard, B. A. \& Peterson, T.D. (1991). Nephelinite-carbonatite liquid immiscibility at Shombole volcano, East Africa: Petrographic and experimental evidence. Mineralogy and Petrology 43, 293-314.

Kjarsgaard, B.A., Hamilton, D.L. \& Peterson, T.D. (1995). Peralkaline nephelinite/carbonatite liquid immiscibility: comparison of phase compositions in experiments and natural lavas from Oldoinyo Lengai. In: Bell, K. \& Keller, J. (eds.) Carbonatite Volcanism. Springer, 163190.

Korobeinikov, A.N., Mitrofanov, F.P., Gehör, S., Laajoki, K., Pavlov, V.P. \& Mamontov, V.P. (1998). Geology and copper sulphide mineralization of the Salmagorskii Ring Igneous Complex, Kola Peninsula, NW Russia. Journal of Petrology 39, 2033-2041.

Koster van Groos, A.F. \& Wyllie, P.J. (1963). Experimental Data bearing on the Role of Liquid Immiscibility in the Genesis of Carbonatites. Nature 199, 801-802

Koster van Groos, A.F. \& Wyllie, P.J. (1973). Liquid immiscibility in the join $\mathrm{NaAlSi}_{3} \mathrm{O}_{8}-\mathrm{CaAISi}_{2} \mathrm{O}_{8}-$ $\mathrm{Na}_{2} \mathrm{CO}_{3}-\mathrm{H}_{2} \mathrm{O}$. American Journal of Science 273, 465-487.

Krogstad, E.J. \& Walker, R.J. (1994). High closure temperatures of the U-Pb system in large apatites from the Tin Mountain Pegmatite, Black Hills, South Dakota, USA. Geochimica and Cosmochimica Acta 58, 3845-3853.

Laplante, R. (1980). Étude de la minéralisation en Nb-Ta-U du complexe ignée alcalin du canton Crevier, Comté Roberval, Lac St-Jean, P.Q. (Unpublished MSc thesis). École Polytechnique de Montréal, 62p.

Lasalle, S. \& Indares, A. (2014). Anatectic record and contrasting P-T paths of aluminous gneisses from the central Grenville Province. Journal of Metamorphic Geology 32, 627-646.

Lasalle, S., Dunning, G. \& Indares, A. (2014). In situ LA-ICP-MS dating of monazite from aluminous gneisses: insights on the tectono-metamorphic history of a granulite-facies domain in the central Grenville Province. Canadian Journal of Earth Sciences 51, 331558 572.

Le Bas, M.J. \& Aspden J.A. (1981). The comparability of carbonatitic fluid inclusions in ijolites and natrocarbonatite lava. Bull. Volcan. 444, 429-438.

Le Bas, M.J. (1987). Nephelinites and carbonatites. In: Fitton, J. G. \& Upton, B. G. J. (eds.) Alkaline Igneous Rocks. Geological Society, London, Special Publications 30, 53-85.

Lee, W.J. \& Wyllie, P.J. (1994). Experimental data bearing on liquid immiscibility, crystal fractionation, and the origin of calciocarbonatites and natrocarbonatites. International Geology Review 36, 797-819. 
Lee, W.J. \& Wyllie, P.J. (1996). Liquid immiscibility in the join $\mathrm{NaAISi}_{3} \mathrm{O}_{8}-\mathrm{CaCO}_{3}$ to $2.5 \mathrm{GPa}$ and the origin of calciocarbonatite magmas. Journal of Petrology 37, 1125-1152.

Lee, W.J. \& Wyllie, P.J. (1997). Liquid immiscibility between nephelinites and carbonatite from 1.0 to $2.5 \mathrm{GPa}$ compared with mantle melt compositions. Contributions to Mineralogy and Petrology 127, 1-16.

Lee, W.J. \& Wyllie, P.J. (1998). Processes of crustal carbonatite formation by liquid immiscibility and differentiation, elucidated by model systems. Journal of Petrology 39, 2005-2013.

Lee, M.J., Lee, J.I., Garcia, D., Moutte, J., Williams, C.T., Wall, F. \& Kim, Y. (2006). Pyrochlore chemistry from the Sokli phoscorite-carbonatite complex, Finland: implications for the genesis of phoscorite and carbonatite association. Geochemical Journal 40, 1-13.

Le Maitre, R., International Union of Geological Sciences. Subcommission on the Systematics of Igneous Rocks, \& ProQuest. (2002). Igneous rocks: A classification and glossary of terms: Recommendations of the International Union of Geological Sciences, Subcommission on the Systematics of Igneous Rocks (2nd ed.). Cambridge, U.K.; New York: Cambridge University Press.

Leveson, D.J. (1966). Orbicular rocks: a review. Bulletin of the Geological Society of America 77, 409-26.

Li, W.Y., Teng, F.Z., Halama, R., Keller, J. \& Klaudius, J. (2016). Magnesium isotope fractionation during carbonatite magmatism at Oldoinyo Lengai, Tanzania. Earth and Planetary Science Letters 444, 26-33.

Linnen, R.L., Samson, I.M., Williams-Jones, A.E., \& Chakhmouradian, A.R. (2014). Geochemistry of the rare-earth element, $\mathrm{Nb}, \mathrm{Ta}, \mathrm{Hf}$, and $\mathrm{Zr}$ deposits. In: Holland, H.D., \& Turekian, K.K. (eds.) Treatise on Geochemistry, Second Edition, Oxford: Elsevier 13, 543-568.

Mackay, D.A.R. \& Simandl, G.J. (2014). Geology, market and supply chain of niobium and tantalum - a review. Mineralium Deposita 49, 1025-1047.

Mao, M., Rukhlov, A.S., Rowins, S.M., Spence, J. \& Coogan, L.A. (2016). Apatite Trace Element Compositions: A Robust New Tool for Mineral Exploration. Economic Geology 111, 1187 1222

Marks, M., Halama, R., Wenzel, T. \& Markl, G. (2004a). Trace element variations in clinopyroxene and amphibole from alkaline to peralkaline syenites and granites: implications for mineralmelt trace element partitioning. Chemical Geology 211, 185-215.

Marks, M., Vennemann, T., Siebel, W. \& Markl, G. (2004b). Nd-, O-, and H-isotopic evidence for complex, closed-system fluid evolution in the peralkaline Ilı'maussaq Intrusion, South Greenland. Geochimica et Cosmochimica Acta 68, 3379-3395. 
Marks, M.A.W. \& Markl, G. (2017). A global review on agpaitic rocks. Earth-Science Reviews 173, 229-258.

McCreath, J.A., Finch, A.A., Simonsen, S.L., Donaldson, C.H. \& Armour-Brown, A. (2012). Independent ages of magmatic and hydrothermal activity in alkaline igneous rocks: the motzfeldt Centre, Gardar province, south Greenland. Contributions to Mineralogy and Petrology 163, 967-982.

1236 McCreath, J.A., Finch, A.A., Herd, D.A. \& Armour-Brown, A. (2012). Geochemistry of pyrochlore minerals from the Motzfeldt Center, South Greenland: The mineralogy of a syenite-hosted $\mathrm{Ta}, \mathrm{Nb}$ deposit. American Mineralogist 98, 426-438.

McCausland, P.J., Pisarevsky, S., Jourdan, F. \& Higgins, M. (2009). Laurentia at 571 Ma: preliminary paleomagnetism and Ar-Ar age of the Ediacaran St. Honore alkali intrusion, Quebec. Proceedings, American Geophysical Union-Geological Association of CanadaMineralogical Association of Canada-Canadian Geophysical Union (CGU), Joint Assembly. Toronto, abs, GA12A-01.

McDonough, W.F. \& Sun, S.-s. (1995). The composition of the Earth. Chemical Geology, Chemical Evolution of the Mantle 120, 223-253.

McLelland, J.M., Selleck, B.W. \& Bickford, M.E. (2013). Tectonic Evolution of the Adirondack Mountains and Grenville Orogen Inliers within the USA. Geoscience Canada 40, 318-352. Middlemost, E.A.K. (1994). Naming materials in the magma/igneous rock system. Earth Science Reviews 37, 215-224.

Miles, A.J., Graham, C.M., Hawkesworth, C.J., Gillespie, M.R., Hinton, R.W., Bromiley, G.D. \& EMMAC (2014). Apatite: A new redox proxy for silicic magmas? Geochimica et Cosmochimica Acta 132, 101-119.

Millong, L.J. \& Groat, L.A. (2013). Carbonatites in western North America: occurrences and metallogeny. Society of Economic Geologists Special Publication 17, 145-164.

Mitchell, R.H. (1996). Classification of undersaturated and related alkaline rocks. In: Mitchell, R.H. (Ed.), Undersaturated Alkaline Rocks: Mineralogy, Petrogenesis, and Economic Potential. Mineral. Association Canada Short Course 24, 1-22.

Mitchell, R.H. (2005). Carbonatites and carbonatites and carbonatites. Canadian Mineralogist 43, 2049-2068.

Mitchell, R.H. (2009). Peralkaline nephelinite-natrocarbonatite immiscibility and carbonatite assimilation at Oldoinyo Lengai, Tanzania. Contributions to Mineralogy and Petrology 158, 589-598. 
Mitchell, R.H. \& Dawson, J.B. (2012). Carbonate-silicate immiscibility and extremely peralkaline silicate glasses from Nasira cone and recent eruptions at Oldoinyo Lengai volcano, Tanzania. Lithos 152, 40-46.

Mollex, G. (2017) Architecture de la plomberie du volcan carbonatitique Oldoinyo Lengai. Ph.D. Université de Lorraine, 195p.

Mollex, G., Füri, E., Burnard, P., Zimmermann, L., Chazot, G., Kazimoto, E.O., Marty, B. \& France, L. (2018). Tracing helium isotope compositions from mantle source to fumaroles at Oldoinyo Lengai volcano, Tanzania. Chemical Geology 480, 66-74.

Moore, K.R. \& Wood, B.J. (1998). The transition from carbonate to silicate melts in the CaO-MgO$\mathrm{SiO}_{2}-\mathrm{CO}_{2}$ system. Journal of Petrology 39, 1943-1951.

Morteani, G., Kostitsyn, Y.A., Gilg, H.A., Preinfalk, C. \& Razakamanana, T. (2013). Geochemistry of phlogopite, diopside, calcite, anhydrite and apatite pegmatites and syenites of southern Madagascar: evidence for crustal silicocarbonatitic (CSC) melt formation in a Panafrican collisional tectonic setting. International Journal of Earth Sciences 102, 627-645.

Nasraoui, M. \& Bilal, E. (2000). Pyrochlore from the Lueshe carbonatite complex (Democratic Republic of Congo): a geochemical record of different alteration stages. Journal of Asian Earth Sciences 18, 237-251.

Nemchin, A.A., Pidgeon, R.T., \& Whitehouse, M.J. (2006). Re-evaluation of the origin and evolution of $>4.2 \mathrm{Ga}$ zircons from the Jack Hills metasedimentary rocks. Earth and Planetary Science Letters 244, 218-233.

Nielsen, T.F.D. (1980). The petrology of a melilitolite, melteigite, carbonatite and syenite ring dike system in the Gardiner complex, East Greenland. Lithos 13,181-197.

Nielsen, T.F.D., Solovova, I.P., \& Veksler, I.V., (1997). Parentalmelts of melilitolite and origin of alkaline carbonatite: evidence from crystallised melt inclusions, Gardiner complex. Contributions to Mineralogy and Petrology 126, 331-344.

Nielsen, T.F.D. \& Veksler, I.V. (2002). Is natrocarbonatite a cognate fluid condensate? Contributions to Mineralogy and Petrology 142, 425-435.

Ohnenstetter, D. \& Piantone, P. (1992). Pyrochlore-group minerals in the Beauvior peraluminous leucogranite, Massif Central, France. Canadian Mineralogist 30, 771-784.

Panina, L.I. (2005). Multiphase carbonate-salt immiscibility in carbonatite melts: data on melt inclusions from the Krestovskiy massif minerals (Polar Siberia). Contributions to Mineralogy and Petrology 150, 19-36.

Peterson, T.D. (1989) Peralkaline nephelinites I. Comparative petrology of Shombole and Oldoinyo Lengai, East Africa. Contributions to Mineralogy and Petrology 101, 458-478. 
Piccoli, P.M., \& Candela, P.A. (2002). Apatite in igneous systems. Reviews in Mineralogy and Geochemistry 48, 255-292.

Platt, R.G. (1996). Nepheline syenite complexes - an overview. In: Mitchell, R.H. (Ed.), Undersaturated Alkaline Rocks: Mineralogy, Petrogenesis, and Economic Potential. Mineral. Association Canada Short Course 24, 63-99.

Pochon, A., Poujol, M., Gloaguen, E., Branquet, Y., Cagnard, F., Gumiaux, C. \& Gapais, D. (2016) $\mathrm{U}-\mathrm{Pb}$ LA-ICP-MS dating of apatite in mafic rocks: Evidence for a major magmatic event at the Devonian-Carboniferous boundary in the Armorican Massif (France). American Mineralogist 101, 2430-2442.

Potter, N.J., Kamenetsky, V.S., Simonetti, A. \& Goemann, K. (2017). Different types of liquid immiscibility in carbonatite magmas: A case study of the Oldoinyo Lengai 1993 lava and melt inclusions. Chemical Geology 455, 376-384.

Pouchou, J.-L., \& Pichoir, F. (1991). Quantitative analysis of homogeneous or stratified microvolumes applying the model "PAP". Electron ProbeQuantification, 31-75.

Rivers, T. (1997). Lithotectonic elements of the Grenville Province: review and tectonic implications. Precambrian Research 86, 117-154.

Rivers, T. (2008). Assembly and preservation of lower, mid, and upper orogenic crust in the Grenville Province-Implications for the evolution of large hot long-duration orogens. Precambrian Research 167, 237-259.

Rivers, T. (2015). Tectonic Setting and Evolution of the Grenville Orogen: An Assessment of Progress Over the Last 40 Years. Geoscience Canada 42, 77-124.

Rivers, T. \& Corrigan, D. (2000). Convergent margin on southeastern Laurentia during the Mesoproterozoic: tectonic implications. Canadian Journal of Earth Sciences 37, 359-83.

Rivers, T. \& Schwerdtner, W. (2015). Post-peak evolution of the Muskoka domain, western Grenville Province: ductile detachment zone in a crustal-scale metamorphic core complex. Geoscience Canada 42, 403-436.

Rivers, T., Culshaw, N., Hynes, A., Indares, A., Jamieson, R. \& Martignole, J. (2012). The Grenville Orogen - A Post-LITHOPROBE Perspective. Tectonic Styles. In: Percival, J.A., Cook, F.A. \& Clowes, R.M. (eds.) Canada: The LITHOPROBE Perspective, 97-236.

Rivers, T., Martignole, J., Gower, C.F. \& Davidson, A. (1989). New tectonic divisions of the Grenville Province, Southeast Canadian Shield. Tectonics 8, 63-84.

Santos, R.V. \& Clayton, R.N. (1995). Variations of oxygen and carbon isotopes in carbonatites: a study of Brazilian alkaline complexes. Geochimica and Cosmochimica Acta 59, 13391352. 
Sekisova, V.S., Sharygin, V.V., Zaitsev, A.N. \& Strekopytov, S. (2015). Liquid immiscibility during crystallization of forsterite-phlogopite ijolites at Oldoinyo Lengai volcano, Tanzania: study of melt inclusions. Russian Geology Geophysics 56, 1717-1737.

Schoene, B. \& Bowring, S.A. (2007). Determining accurate temperature-time paths from U-Pb thermochronology: An example from the Kaapvaal craton, southern Africa. Geochimica et Cosmochimica Acta 71, 165-185.

Sha, L.K. \& Chappell, B.W. (1999). Apatite chemical composition, determined by electron microprobe and laser-ablation inductively coupled plasma mass spectrometry, as a probe into granite petrogenesis. Geochimica et Cosmochimica Acta 63, 3861-3881.

Sharygin, V.V., Kamenetsky, V.S., Zaitsev, A.N. \& Kamenetsky, M.B. (2012). Silicatenatrocarbonatite liquid immiscibility in 1917 eruption combeite-wollastonite nephelinite, Oldoinyo Lengai Volcano, Tanzania: Melt inclusion study. Lithos 152, 23-39.

Shrinivas, G.V. \& Bismayer, U. (2010). Compositional variation in pyrochlores of Amba Dongar carbonatite complex, Gujara. Journal of the Geological Society of India 75, 495-502.

Solgadi, F., Groulier, P.-A., Moukhsil, A., Ohnenstetter, D., André-Mayer, A.-S. \& Zeh, A. (2015). Nb-Ta-REE mineralization associated with the Crevier alkaline intrusion. In: Simandl, G.J. and Neetz, M., (Eds.), Symposium on Strategic and Critical Materials Proceedings, November 13-14, 2015, Victoria, British Columbia. British Columbia Ministry of Energy and Mines, British Columbia Geological Survey Paper 2015-3, 69-74.

Soucy La Roche, R., Gervais, F., Tremblay, A., Crowley, J.L. \& Ruffet, G. (2015). Tectonometamorphic history of the eastern Taureau shear zone, Mauricie area, Québec: implications for the exhumation of the mid-crust in the Grenville Province. Precambrian Research 257, 22-46.

Stacey, J.S. \& Kramers, J.D. (1975). Approximation of terrestrial lead isotope evolution by a twostage model. Earth and Planetary Science Letters 26, 207-221.

Storey, C.D., Smith, M.P., \& Jeffries, T.E. (2007). In situ LA-ICP-MS U-Pb dating of metavolcanics of Norrbotten, Sweden: Records of extended geological histories in complex titanite grains. Chemical Geology 240, 163-181.

Suk, N. I. (2001). Experimental study of liquid immiscibility in silicate-carbonate systems. Petrology 9, 477-487.

Taubald, H., Morteani, G., Satir, M. (2004). Geochemical and isotopic (Sr, C, O) data from the alkaline complex of Grønnedal-Ika (South Greenland): evidence for unmixing and crustal contamination. International Journal of Earth Sciences 93, 348-360. 
Taylor, H.P., Frechen, J. \& Degens, E.T. (1967). Oxygen and carbon isotope studies of carbonatites from the Laacher See District, West Germany and the Alnö District, Sweden. Geochimica et Cosmochimica Acta 31, 407-430.

Tera, F. \& Wasserburg, G.J. (1972). U-Th-Pb systematics in lunar highland samples from the Luna 20 and Apollo 16 missions. Earth and Planetary Science Letters 17, 36-51.

Thompson, A.B., Aerts, M. \& Hack, A.C. (2007). Liquid immiscibility in silicatemelts and related systems. Reviews in Mineralogy and Geochemistry 65, 99-127.

Thomson, S.N., Gehrels, G.E., Ruiz, J. \& Buchwaldt, R. (2012). Routine low damage apatite U$\mathrm{Pb}$ dating using laser ablation-multicollector-ICPMS. Geochemistry, Geophysics, Geosystems, 13, Q0AA21.

Torró, I, Villanova, C., Castillo, M., Campeny, M., Gonçalves, A.O. \& Melgarejo, J.C. (2012). Niobium and rare earth minerals from the Virulundo carbonatite, Namibe, Angola. Mineralogical Magazine 76, 393-409.

Treiman, A.H. \& Essene, E.J. (1985). The Oka carbonatite complex, Quebec: geology and evidence for silicate-carbonate liquid immiscibility. American Mineralogist 70, 1101-1113.

Tremblay, J., Bédard, L.P., \& Matton, G. (2015). A petrographic study of Nb-bearing minerals at the Saint-Honoré niobium deposit. In: Simandl, G.J. \& Neetz, M. (Eds.), Symposium on Strategic and Critical Materials Proceedings, November 13-14, 2015, Victoria, British Columbia. British Columbia Ministry of Energy and Mines, Bristish Columbia Geological Survey Paper 2015-3, pp.75-81.

Turlin, F., André-Mayer, A.-S., Moukhsil, A., Vanderhaeghe, O., Gervais, F., Solgadi, F., Groulier, P.-A. \& Poujol, M. (2017). Unusual LREE-rich, peraluminous, monazite- or allanite-bearing pegmatitic granite in the central Grenville Province, Québec. Ore Geology Reviews 89, 627-667.

Turlin, F., Deruy, C., Eglinger, A., Vanderhaeghe, O., André-Mayer, A.-S., Poujol, M. Moukhsil, A. \& Solgadi, F. (2018). A 70 Ma record of suprasolidus conditions in the large, hot, longduration Grenville Orogen. Terra Nova 30, 233-243.

Turlin, F., Vanderhaeghe, O., Gervais, F., André-Mayer, A.-S., Moukhsil, A., Zeh, A., Solgadi, F. \& I.P.T.N. (2019). Petrogenesis of LREE-bearing pegmatitic granite dykes in the central Grenville Province by partial melting of Paleoproterozoic-Archean metasedimentary rocks: evidence from zircon $\mathrm{U}-\mathrm{Pb}-\mathrm{Hf}-\mathrm{O}$ isotope and trace element analyses. Precambrian Research 327C, 327-360. 
Ulmer, P. \& Sweeney, R. J. (2002). Generation and differentiation of group II kimberlites: Constraints from a high-pressure experimental study to $10 \mathrm{GPa}$. Geochimica et Cosmochimica Acta 66, 2139-2153.

Valley, J.W., Lackey, J.S., Cavosie, A.J., Clechenko, C.C., Spicuzza, M.J., Basei, M.A.S., Bindeman, I.N., Ferreira, V.P., Sial, A.N., King, E.M., Peck, W.H., Sinha, A.K. \& Wei, C.S. (2005). 4.4 billion years of crustal maturation: oxygen isotope ratios of magmatic zircon. Contrib. Mineral. Petrol. 150, 561-580.

van Gool, J.A.M., Rivers, T. \& Calon, T. (2008). Grenville Front zone, Gagnon terrane, southwestern Labrador: configuration of a midcrustal foreland fold-thrust belt. Tectonics 27 , TC1004.

Veksler, I.V., Petibon, C., Jenner, G.A., Dorfman, A.M. \& Dingwell, D.B. (1998a). Trace element partitioning in immiscible silicate-carbonate liquid systems: an initial experimental study using a centrifuge autoclave. Journal of Petrology 39, 2095-2104.

Veksler, I.V., Nielsen, T.F.D. \& Sokolov, S.V. (1998b). Mineralogy of crystallized melt inclusions from Gardiner and Kovdor ultramafic alkaline complexes: implications for carbonatite genesis. Journal of Petrology 39, 2015-2031.

Veksler, I.V., Dorfman, A.M., Dulski, P., Kamenetsky, V.S., Danyushevsky, L.V., Jeffries, T. \& Dingwell, D.B. (2012). Partitioning of elements between silicate melt and immiscible fluoride, chloride, carbonate, phosphate and sulfate melts, with implications to the origin of natrocarbonatite. Geochimica and Cosmochimica Acta 79, 20-40.

Verplanck, P.L., Mariano, A.N. \& Mariano A. Jr (2016). Rare Earth Element Ore Geology of Carbonatites. Reviews in Economic Geology 18, 5-32.

Wallace, M.E. \& Green, D.H. (1988). An experimental determination of primary carbonatite magma composition. Nature 335, 343-346.

Walter, B.F., Parsapoor, A., Braunger, S., Marks, M.A.W., Wenzel, T., Martin, M. \& Markl, G. (2018). Pyrochlore as a monitor for magmatic and hydrothermal processes in carbonatites from the Kaiserstuhl volcanic complex (SW Germany). Chemical Geology 498, 1-16.

Watkinson, D. H. \& Wyllie, P. J. (1971). Experimental study of composition join $\mathrm{NaAlSiO}_{4}-\mathrm{CaCO}_{3}-$ $\mathrm{H}_{2} \mathrm{O}$ and genesis of alkali rock-carbonatite complexes. Journal of Petrology 12, 357-378.

Wiedenbeck, M., Hanchar, J., Peck, W.H., Sylvester, P., Valley, J., Whitehouse, M., Kronz, A., Morishita, Y., Nasdala, L., et al. (2004). Further characterization of the 91500 zircon crystal. Geostandards and Geoanalytical Research 28, 9-39.

Whitmeyer, S.J. \& Karlstrom, K.E. (2007). Tectonic model for the Proterozoic growth of North America. Geosphere 3, 220-259. 
Winter, J.D. (2001) An introduction to igneous and metamorphic petrology. New Jersey, Prentice Hall, $697 \mathrm{p}$.

Wyllie, P. J. \& Huang, W.L. (1976). Carbonation and melting reactions in the system CaO-MgO$\mathrm{SiO}_{2}-\mathrm{CO}_{2}$ at mantle pressures with geophysical and petrological applications. Contributions to Mineralogy and Petrology 54, 79-107.

Xu, C., Zhang, H., Huang, Z., Liu, C., Qi, L., Li, W. \& Guan, T. (2004). Genesis of the carbonatitesyenite complex and REE deposit at Maoniuping, Sichuan Province, China: Evidence from $\mathrm{Pb}$ isotope geochemistry. Geochemical Journal 38, 67-76

Zaitsev, A.N., Williams, C.T., Wall, F. \& Zolotarev, A.A. (2012). Evolution of Chemical Composition of Pyrochlore Group Minerals from Phoscorites and Carbonatites of the Khibina Alkaline Massif. Geology of Ore Deposits 54, 503-515.

Zeh, A. \& Gerdes, A. (2012). U-Pb and Hf isotope record of detrital zircons from gold-bearing sediments of the Pietersburg Greenstone Belt (South Africa)-Is there a common provenance with the Witwatersrand Basin? Precambrian Research 204, 46-56.

Zeh, A., Cabral, A., Koglin, N. \& Decker, M. (2018). Rutile alteration and authigenic growth in metasandstones of the Moeda Formation, Minas Gerais, Brazil - a result of Transamazonian fluid-rock interaction. Chemical Geology 483, 397-409.Zheng, Y.F. (1993). Calculation of oxygen isotope fractionation in anhydrous silicate minerals. Geochimica and Cosmochimica Acta 57, 1079-1091.

Zheng, L., Gu, X. \& Zhang, Y. (2014). Pyrochlore Chemistry from the Bonga Carbonatite-type Nb Deposit, Huila Province, Angola: Implications for Magmatic-Hydrothermal Processes of Carbonatite. Acta Geologica Sinica 88, 487-488. 


\section{Figure captions}

Figure 1. (a) Position of the Grenville orogen in Laurentia: Paleozoic and younger cover are omitted (modified from Hoffman, 1989; Rivers, 2008; Rivers et al., 2012). The northern dashed line represents the boundary between Internal and External Paleoproterozoic Laurentia and the southern dashed line represents the Grenville Front (GF). Abbreviations: 1 = exposed Grenville Province, light grey represents the inferred extension of subsurface allochthonous Grenville Province; 2 = Granite-Rhyolite Igneous Province, ca. 1.50-1.34 Ga and reworked equivalents in the Grenville Province; $3=$ MidContinental Rift system; 4 = Paleoproterozoic orogens, ca. 1.9-1.8 Ga, ca. 1.65 Ga and reworked equivalents in the Grenville Province; 5 = Archean cratons; GF = Grenville Front. (b) Simplified tectonic map of the Grenville Province (modified after Rivers, 2008; Rivers et al., 2012). Letters in stars represent the localization of the main alkaline suites intruding the Allochthonous Belt of the Grenville Province from the early-Neoproterozoic to Mesozoic and their association to post-Grenvillian grabens: 1 = Crevier alkaline suite (958.7 $\pm 3.7 \mathrm{Ma}) ; 2$ = Manitou and Iron Islands alkaline complexes (ca. $577 \mathrm{Ma}) ; 3$ = St-

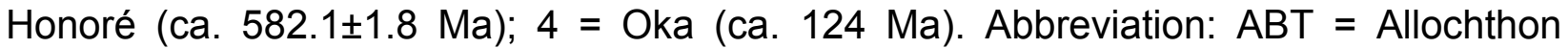
Boundary Thrust.

Figure 2. (a) Simplified regional geology of the Crevier alkaline suite. (b) Detailed mapping of the Crevier alkaline intrusion (modified after Bergeron, 1980; Groulier et al., 2014). Numbers refer to the drill core samples. Abbreviation: NTS $=$ National Topographic System. 
Figure 3. (a) Detailed mapping of the exploration stripped outcrops located in the central south-eastern part of the CAI highlighting the different crosscutting relations. (b) Detailed mapping of the different facies of nepheline syenite in the main unit. (c) Field photograph showing the relation between the pegmatitic nepheline syenite dyke swarm, the silicocarbonatite and the fine- to coarse-grained nepheline syenite (nepheline syenite on the figure). (d) Dykes of pegmatitic nepheline syenite together with their finer-grained feeder conduits and characterized by walls of megacrystic nepheline and albite (up to 50 $\mathrm{cm}$ long) together with dark mica crystallizing inward from the dyke walls. (e) Ferrocarbonatite with iron carbonate and calcite. (f) Pegmatitic nepheline syenite crosscuts by veins of carbonatite with biotite rims. (g) Fragment of coarse-grained carbonatite within fine-grained carbonatite. (h) Hand specimen of silicocarbonatite composed of biotite, carbonate with minor aegirine and crosscut by a vein of carbonatite.

Figure 4. Microphotographs of the lithologies from the Crevier alkaline intrusion. (a) to (c) Macrophotographs of the spectacular ocelli-textured/oecelli facies, with spheres of carbonate-bearing nepheline syenite rimmed by mica in a carbonatite and apatite-rich matrix. (d) ljolite characterized by porphyritic texture and marked by euhedral nepheline, clinopyroxene of aegirine composition, perthitic alkali-feldspar phenocrysts with Carlsbad twins, and titanite as accessory mineral. (e) and (f) Nepheline syenite with albite, perthitic alkali feldspar and nepheline locally altered in cancrinite. (g) holocrystalline and equigranular coarse-grained nepheline syenite, with perthitic alkali feldspars, albite, nepheline, commonly altered in cancrinite, and pyrochlore and Fe-oxides as accessory minerals. (h) aegirine-mica-albite-carbonate-bearing silicocarbonatite enriched in $\mathrm{Fe}-\mathrm{Ti}$ oxides. (i) Coarse-grained carbonatite with fluoroapatite grains. Abbreviations: $A b=a l b i t e$; 
Aeg $=$ aegirine $; \mathrm{Ap}=$ apatite $;$ Cal $=$ calcite $;$ Carb $=$ carbonates $;$ Ccn = cancrinite $;$ Coarse g. = coarse-grained; Ne/Neph. = nepheline; $\mathrm{Ox}=$ oxide $; \mathrm{Pcl}=$ pyrochlore $; \mathrm{Phl}=$ phlogopite.

Figure 5. (a) Total alkali versus silica (TAS) diagram (Middlemost, 1994) showing the medium composition of ijolite (black star) between the carbonate-bearing and carbonatefree nepheline syenite (dark grey symbols) and the silicocarbonatite (white symbols). (b) Peraluminous index $\mathrm{A}(\mathrm{Al}-(\mathrm{K}+\mathrm{Na}+2 \mathrm{Ca}))$ versus differentiation index $\mathrm{B}(\mathrm{Fe}+\mathrm{Mg}+\mathrm{Ti})$ diagram (Debon \& Le Fort, 1988) placing the location of the mineralogical poles (muscovite, biotite, quartz, alkali feldspar, pyroxene, aegirine, nepheline and calcite).

Figure 6. Harker diagrams showing the relation between $\mathrm{SiO}_{2}$ (wt.\%) and $\mathrm{Na}_{2} \mathrm{O}$ (wt.\%) (a), $\mathrm{Al}_{2} \mathrm{O}_{3}$ (wt.\%) (b), $\mathrm{CaO}$ (wt.\%) (c), and $\mathrm{TiO}_{2}$ (wt.\%) (d) contents. Two geochemical trends are identified from an initial ijolitic composition, one with the nepheline syenite lithologies, the other one with the silicocarbonaite lithologies, same legend than in Fig. 5, white triangle represents the carbonatite.

Figure 7. REE spectra of the different Crevier alkaline intrusion facies. All facies display fractionation between LREE and HREE. The ijolite is among the least enriched rocks of the CAI, its REE pattern is marked by little fractionation between LREE and HREE. The fine- to coarse-grained nepheline syenite facies are variably enriched in LREE relative to chondrite as it tends to have flat HREE patterns. ${ }^{1}$ : Normalization after McDonough and Sun (1995). 
Figure 8. (a) and (b) SEM images of apatite from the carbonatite. (c) to (e) Mn-Na-Ca, $\mathrm{Mn}-\mathrm{Fe}-\mathrm{Ca}$ and $\mathrm{Mn}-\mathrm{Fe}-\mathrm{Ce}$ ternary plots of apatite compositions. Shaded areas represent apatite formed from carbonatitic melts (Piccoli \& Candella, 2002).

Figure 9. Petrographic and geochemical features of pyrochlore observed in the nepheline syenite, pegmatitic nepheline syenite and carbonate-bearing ocelli-textured/orbicular facies. (a) The BSE images reveal that a majority of primary magmatic pyrochlore grains exhibit complex zoning and intern patterns. (b) Nb-Ti-Ta ternary diagram showing the fields of composition of pyrochlore, betafite and microlite. The primary grains analyzed in the CAI are all falling in the pyrochlore field (Nb-dominant). Pyrochlore grains from the pegmatitic nepheline syenite (silicate-bearing) and carbonate-bearing ocellitextured/orbicular nepheline syenite show different trend of evolution. (c) $\mathrm{Ta}^{5+}$ vs $\mathrm{Ti}^{4+}$ diagram (values in a.p.f.u.) displaying the different substitution trends for pyrochlore from silicate-bearing and carbonate-bearing facies. Pyrochlore grains from carbonate-bearing facies define a trend marked by an increase of the Ta content with small variations in $\mathrm{Ti}$, implying that the isomorphic substitution $\mathrm{Nb}^{5+}=\mathrm{Ta}^{5+}$ is dominant (d) Diagram $\mathrm{Nb}^{5+} \mathrm{vs} \mathrm{Ta}^{5+}$ (values in a.p.f.u.), the arrows highlight the substitution trends for pyrochlore from NS and CS facies. (e) $\mathrm{Ti}^{4+}$ vs $\mathrm{Nb}^{5+}$ diagram (values in a.p.f.u.) highlighting the isomorphic substitution of $\mathrm{Nb}^{5+}$ by $\mathrm{Ta}^{5+}$ with the pyrochlore from the carbonate-bearing facies that form a linear trend. (f) $\mathrm{Ta}^{5+} \mathrm{vs} \mathrm{Nb/Ta}$ plot showing the distribution of values for pyrochlore grains from silicate- and carbonate-bearing facies. Abbreviations: $\mathrm{Ab}=$ albite; $\mathrm{Cal}=$ calcite $; \mathrm{Pcl}=$ pyrochlore; $\mathrm{Phl}=$ phlogopite . 
Figure 10. Cathodoluminescence images of the zircon grains of the coarse-grained nepheline syenite. The indicated zircon number refers to Table 5, where all analyses are summarized. Trace elements (blue) and $\delta^{18} \mathrm{O}$ (red) results are plotted on each zircon. (a) (Sub)-euhedral zircon grains showing oscillatory zoned cores and sharp dissolutionreprecipitation rims, (b) Zircon grains $\mathrm{n}^{\circ} 15$ and $\mathrm{n}^{\circ} 19$ that distinguished themselves from the populations (a) and (b), as they present significant geochemical variations from core to rim (see Fig. 10 and Table 5), and (c) Anhedral zircons grains, with complex oscillatory zoning and local dissolution-reprecipitation rims.

Figure 11. Cathodoluminescence images of the zircon grains of the coarse-grained nepheline syenite. The indicated zircon number refers to Table 5, where all analyses are summarized. U-Pb LA-ICP-MS results are plotted on each zircon, with indication of degree of discordance. (a) (Sub)-euhedral zircon grains showing oscillatory zoned cores and sharp dissolution-reprecipitation rims, (b) Zircon grains $n^{\circ} 15$ and $n^{\circ} 19$ that distinguished themselves from the populations (a) and (b), as they present significant geochemical variations from core to rim (see Fig. 10 and Table 5), and (c) Anhedral zircons grains, with complex oscillatory zoning and local dissolution-reprecipitation rims.

Figure 12. Trace element geochemistry of the zircons of the coarse-grained nepheline syenite (a) $\mathrm{Ca}+\mathrm{Fe}(\mathrm{ppm})$ vs Th/U diagram. (b) $\mathrm{Ca}+\mathrm{Fe}$ (ppm) vs $\Sigma$ LREE (ppm) diagram. (c) $\mathrm{Ca}+\mathrm{Fe}(\mathrm{ppm})$ vs $\mathrm{Sr}(\mathrm{ppm})$ diagram. (d) $\mathrm{Ca}+\mathrm{Fe}(\mathrm{ppm})$ vs Temperature $\left({ }^{\circ} \mathrm{C}\right)$ calculated with Ti-in-zircon thermometer \pm 60 to $70{ }^{\circ} \mathrm{C}$ (Ferry \& Watson, 2007). Note that the Ti-in zircon thermometer yields consistent temperatures for Ca-Fe-poor grains whereas 
calculated temperatures for $\mathrm{Ca}$-Fe-rich grains are unrealistic. (e) $\mathrm{Ca}+\mathrm{Fe}(\mathrm{ppm})$ vs $\mathrm{Sm}_{N} / \mathrm{Yb}_{\mathrm{N}}$ diagram. (f) REE patterns normalized to chondrite.

Figure 13. $\delta^{13} \mathrm{C}\left(\%\right.$ PDB) vs $\delta^{18} \mathrm{O}(\%$ SMOW) diagram of carbonates from carbonatites. The grey area defines the primary carbonatite field (Taylor et al., 1967). Arrows indicate the main processes responsible for isotopic composition variations (Deines, 1989; Démeny et al., 1998). Abbreviations: High T = high temperature; Low T = low temperature.

Figure 14. (a) Discrimination of the (Sub)-euhedral and anhedral zircon population regarding their $\delta^{18} \mathrm{O}$ composition. (Sub)-euhedral zircon are interpreted as witness of the pre- to syn-immiscibility with carbonate signature, whereas anhedral zircon may be more characteristic of post-immiscibility with no carbonate contribution in their $\delta^{18} \mathrm{O}_{\mathrm{V} \text {-SMow }}$ signature. Light grey area represents the mantle zircon value, as the dark grey area the carbonatite $\delta^{18} \mathrm{O}_{\mathrm{V} \text {-smow }}$ composition. (b) $\delta^{18} \mathrm{O}_{\mathrm{V} \text {-smow }} \mathrm{vs} \mathrm{Ca}+\mathrm{Fe}(\mathrm{ppm})$ diagram of zircon showing the positive correlation between the $\delta^{18} \mathrm{O}_{\mathrm{V} \text {-smow }}$ signatures and the $\mathrm{Ca}+\mathrm{Fe}$ contents of zircon grains. Note that anhedral Ca-Fe-poor zircon have $\delta^{18} \mathrm{O}_{\mathrm{V} \text {-smow }}$ signatures that range from 1.9 and $3.15 \%$ whereas (sub)-euhedral Ca-Fe-rich zircon have $\delta^{18} \mathrm{O}_{\mathrm{V} \text {-smow }}$ signatures that trend towards the carbonates' signatures. A temporal path is proposed for zircon crystallization from mantle zircon value to carbonatite composition before or during the immiscibility process, ending with low values following immiscibility as observed in zircon from a carbonate-free syenite. 
Figure 15. (a) LA-ICP-MS U-Pb ages of zircon from the coarse-grained nepheline syenite facies $(\mathrm{SNg})(\mathrm{n}=17)$; (b) ${ }^{206} \mathrm{~Pb} / 207 \mathrm{~Pb}$ age degree of concordance $(\%)$ vs the $\mathrm{Ca}+\mathrm{Fe}$ content in ppm diagram of zircon. It expresses the correlation between high level of concordance and the low content of $\mathrm{Ca}+\mathrm{Fe}$. (c) Probability diagram of U-Pb ages on zircon; (d) LA-ICP-MS U-Pb ages of apatite from the carbonatite facies $(n=24)$.

Figure 16. Plot of the different lithologies of the CAI in the Freestone and Hamilton projection (1980). The whole rock composition of the nepheline syenite and silicocarbonatite lithologies follow the nepheline-carbonatite melt miscibility gap proposed by Kjarsgaard and Peterson (1991; solvus at $0.5 \mathrm{GPa}, 1050-900^{\circ} \mathrm{C}$ ). The carbonatite composition does not fit with this experimental miscibility gap, with a silica-alkali-poor composition. This may be link to the modification of the initial magmatic composition by late-stage magmatic or secondary processes leading to silica-alkali-depleted to -free carbonatite bulk compositions.

Figure 17. Synthesis of the results presented in this study allowing to decipher the evolution of the Crevier alkaline intrusion through the immiscibility process between a syenitic and a carbonatitic melts. Abbreviations: Allocht. Crust $=$ Allochthonous crust; Cal $=$ calcite $; \mathrm{Ccn}=$ cancrinite $; \mathrm{Ne} / \mathrm{Neph} .=$ nepheline $; \mathrm{Phl}=$ phlogopite $;$ Temp. = temperature; Zrc = zircon 


\section{Table caption}

Table 1. Present coordinates and results presented in this study of the various facies of the Crevier alkaline intrusion from the central Grenville Province sampled for this study, ordered by outcrop. Abbreviation: Neph. = nepheline; $\mathrm{Cb}$-bearing NS $=$ Carbonate-bearing nepheline syenite.

Table 2. Whole-rock geochemistry of the plutonic rocks from the various facies identified in the Crevier alkaline intrusion from the central Grenville Province, ordered by rock type. Abbreviations: $\mathrm{C}=(\mathrm{Fe}, \mathrm{Ca})$-carbonatite; $\mathrm{Cb}$-bearing $\mathrm{NS}=$ carbonate-bearing nepheline syenite; $\mathrm{LOI}=$ loss on ignition; $\mathrm{Mg} \#=(\mathrm{Mg}) /(\mathrm{Mg}+\mathrm{Fe}) ; \mathrm{NS}=$ nepheline syenite; $\mathrm{NSg}=$ coarse-grained nepheline syenite; $\mathrm{NSp}=$ pegmatitic nepheline syenite; $\mathrm{SC}=$ Silicocarbonatite.

Table 3. Representative magmatic pyrochlore compositions and structural formula from different syenite facies of the Crevier alkaline intrusion from the central Grenville Province obtained using EPMA. Abbreviations: apfu = atoms per formula unit; Neph. Sye. = nepheline syenite. General formula: $A_{2-m} B_{2} X_{6-w} Y_{1-n}$ (Atencio et al., 2010) with $m, w$ and $n$ corresponding to the vacancies of the different sites.

Table 4. Apatite compositions from carbonatite facies (sample 12-PA-007-A6) of the Crevier alkaline intrusion from the central Grenville Province obtained using EPMA. They are reported with confidence interval of $95 \%$ in brackets ( $n=$ number of analyses). 
Table 5. Summary of the results obtained on zircon grains from the carbonate-bearing nepheline syenite (sample 12-PA-011-B11) of the Crevier alkaline intrusion from the central Grenville Province. The zircon grains are grouped according to the classification of Figs. 10 and 11. Abbreviation: Temp. = temperature. .

Table 6. U-Pb dating of apatite from carbonatite facies (sample 12-PA-007-A6) of the Crevier alkaline intrusion from the central Grenville Province.

Table 7. $\delta^{18} \mathrm{O}_{\mathrm{V}-\mathrm{SMOW}}$ and $\delta^{13} \mathrm{C}_{\mathrm{V} \text {-PDB }}$ composition of calcite from carbonatite facies (samples 12-PA-019-A, 12-PA-007-A6 and 12-PA-009-A5) of the Crevier alkaline intrusion from the central Grenville Province.

Table S1. Magmatic pyrochlore compositions and structural formula from different syenite facies of the Crevier alkaline intrusion from the central Grenville Province obtained using EPMA. apfu = atoms per formula unit; Neph. Sye. = nepheline syenite. General formula: $A_{2-m} B_{2} X_{6-w} Y_{1-n}$ (Atencio et al., 2010) with $m, w$ and $n$ corresponding to the occupancy of the different sites.

Table S2. Results of trace elements LA-ICP-MS measurements of zircon grains from the carbonate-rich coarse-grained nepheline syenite (sample 12-PA-032) of the Crevier alkaline intrusion from the central Grenville Province. Abbreviation: PGD = pegmatitic granite dyke. 
Table S3. Results of LA-ICP-MS U-Pb dating of zircon grains from the carbonate-rich coarse-grained nepheline syenite (sample 12-PA-032) of the Crevier alkaline intrusion from the central Grenville Province. Abbreviation: conc. $=$ degree of concordance.

Table S4. Operating conditions for the LA-ICP-MS equipment dedicated to U-Pb dating of apatite grains.

Table S5. Results of SIMS O isotope analyses of zircon grains from the carbonate-bearing coarse-grained nepheline syenite (sample 12-PA-032) of the Crevier alkaline intrusion from the central Grenville Province. 
Figure 1 (black and white; 2 columns fitting)

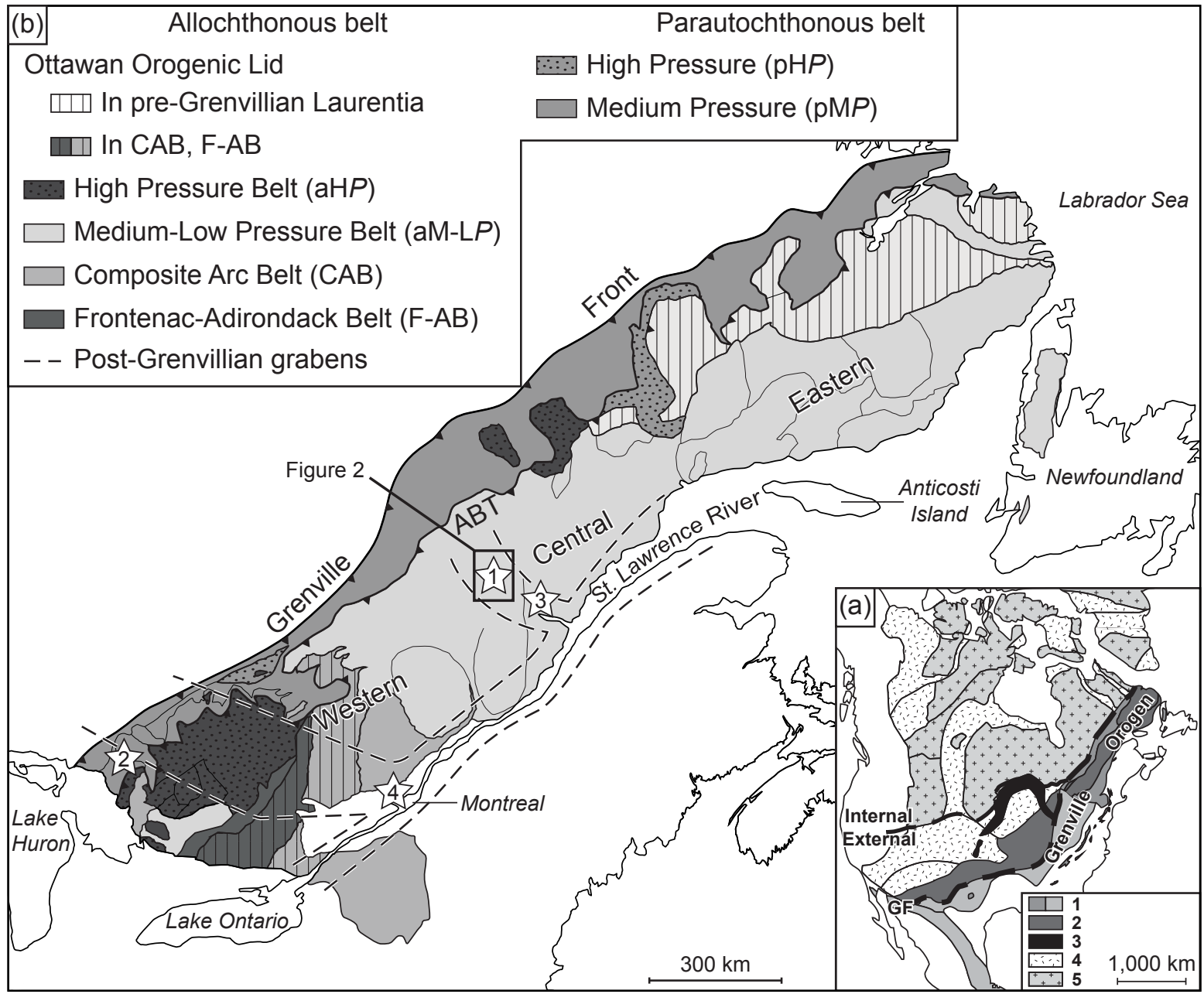


Figure 2 (color; 2 columns fitting)

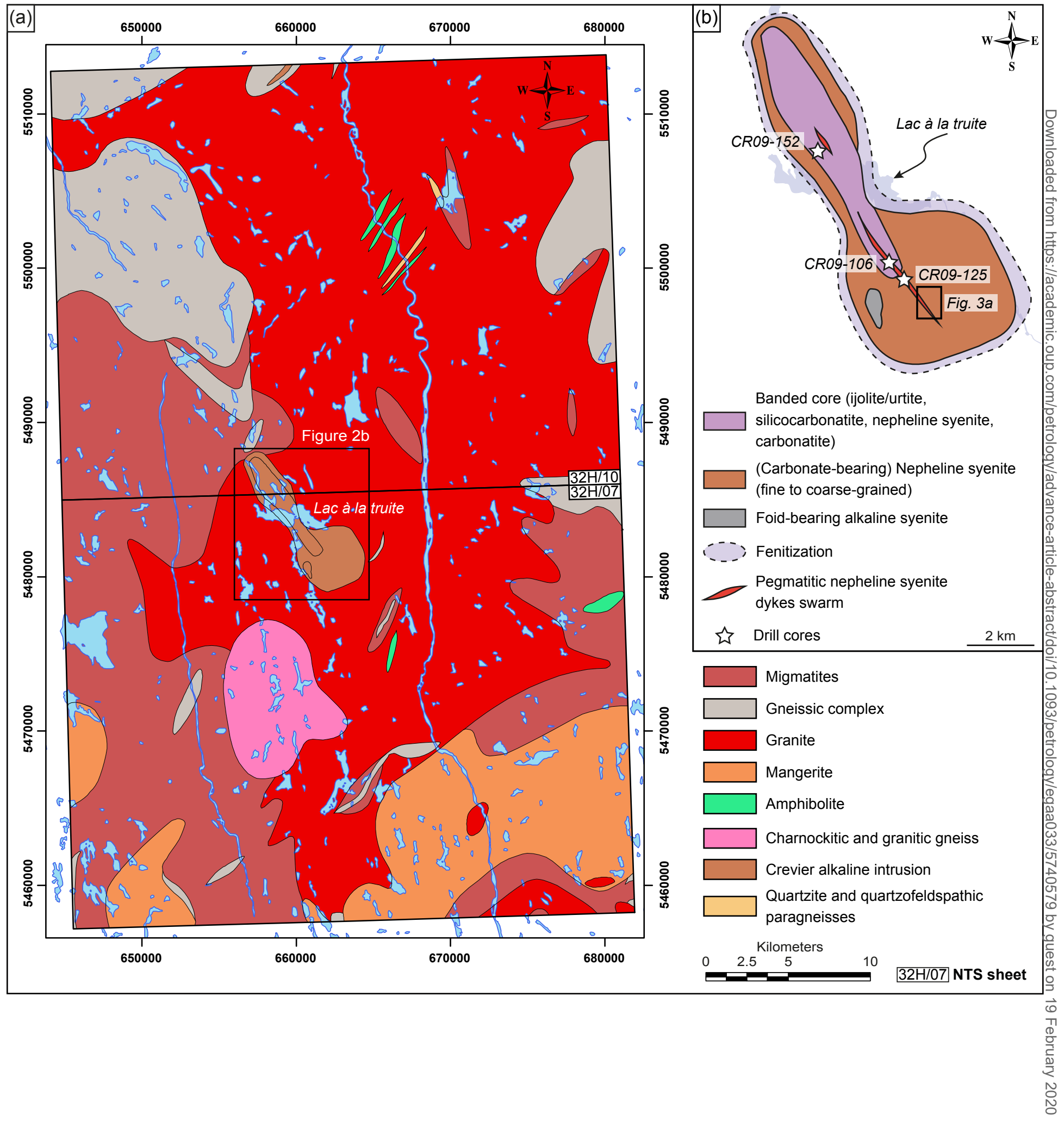


Figure 3 (a) to (h) (color; 2 columns fitting)
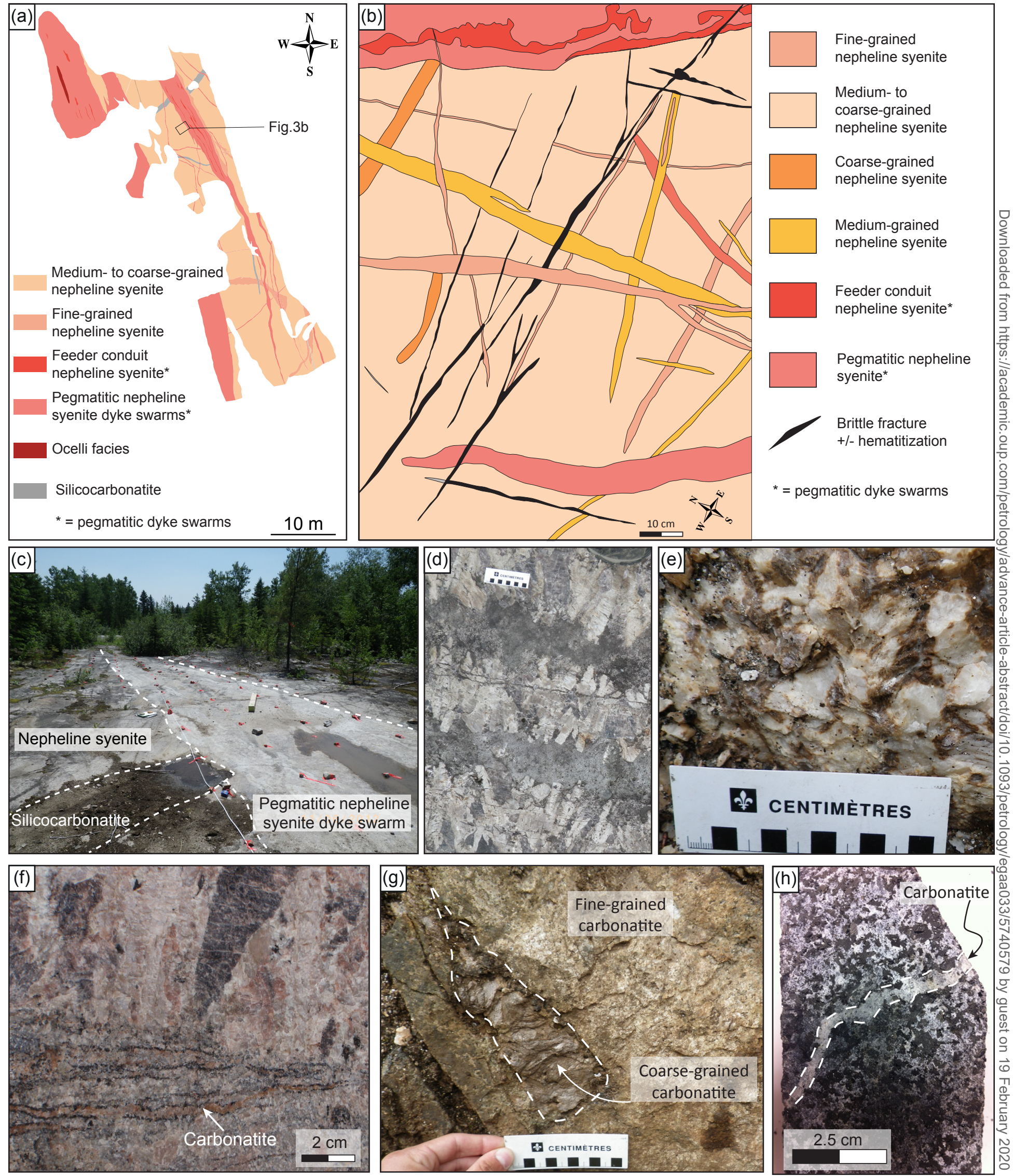
Figure 4 (color; 2 columns fitting)
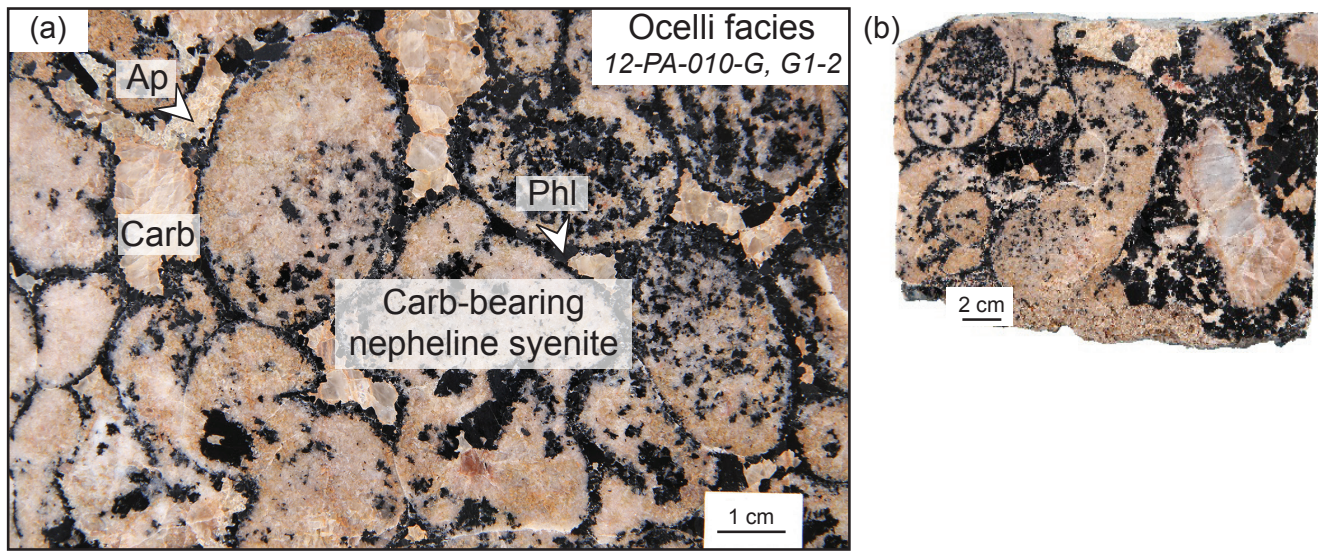

Ocelli facies

12-PA-010-G, G1-2
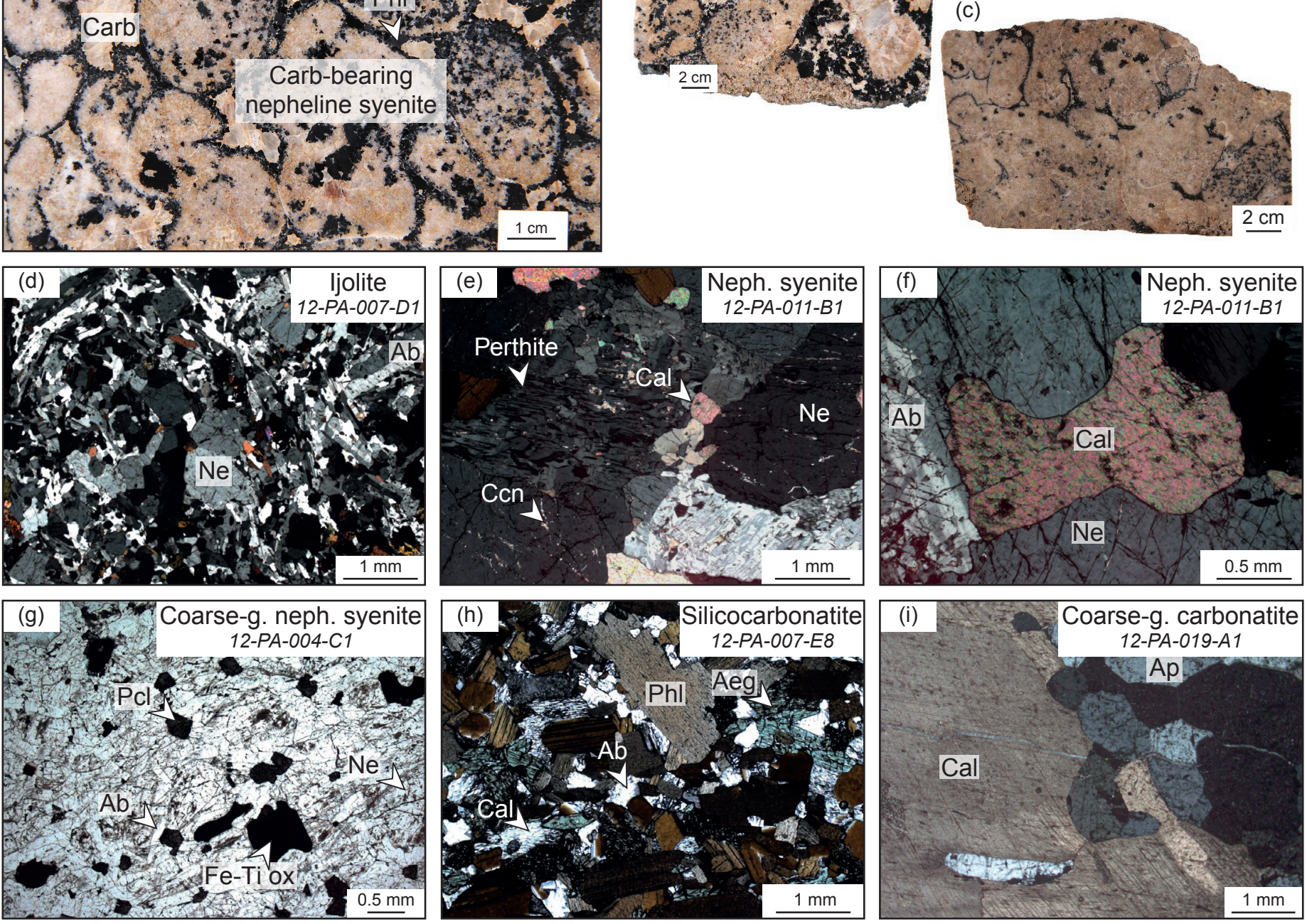
Figure 5 (black and white; 1 column fitting)
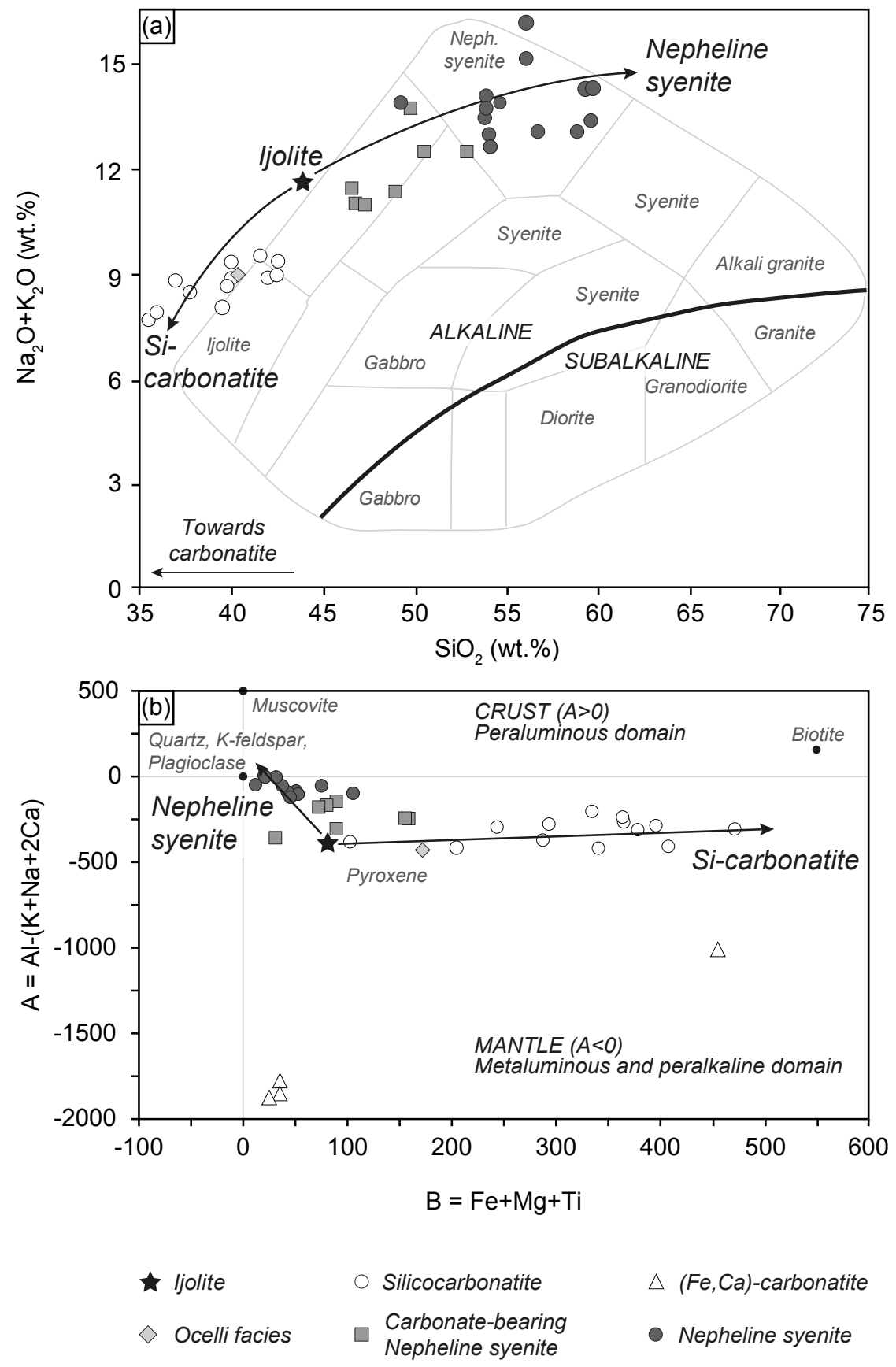
Figure 6 (black and white; 2 columns fitting)
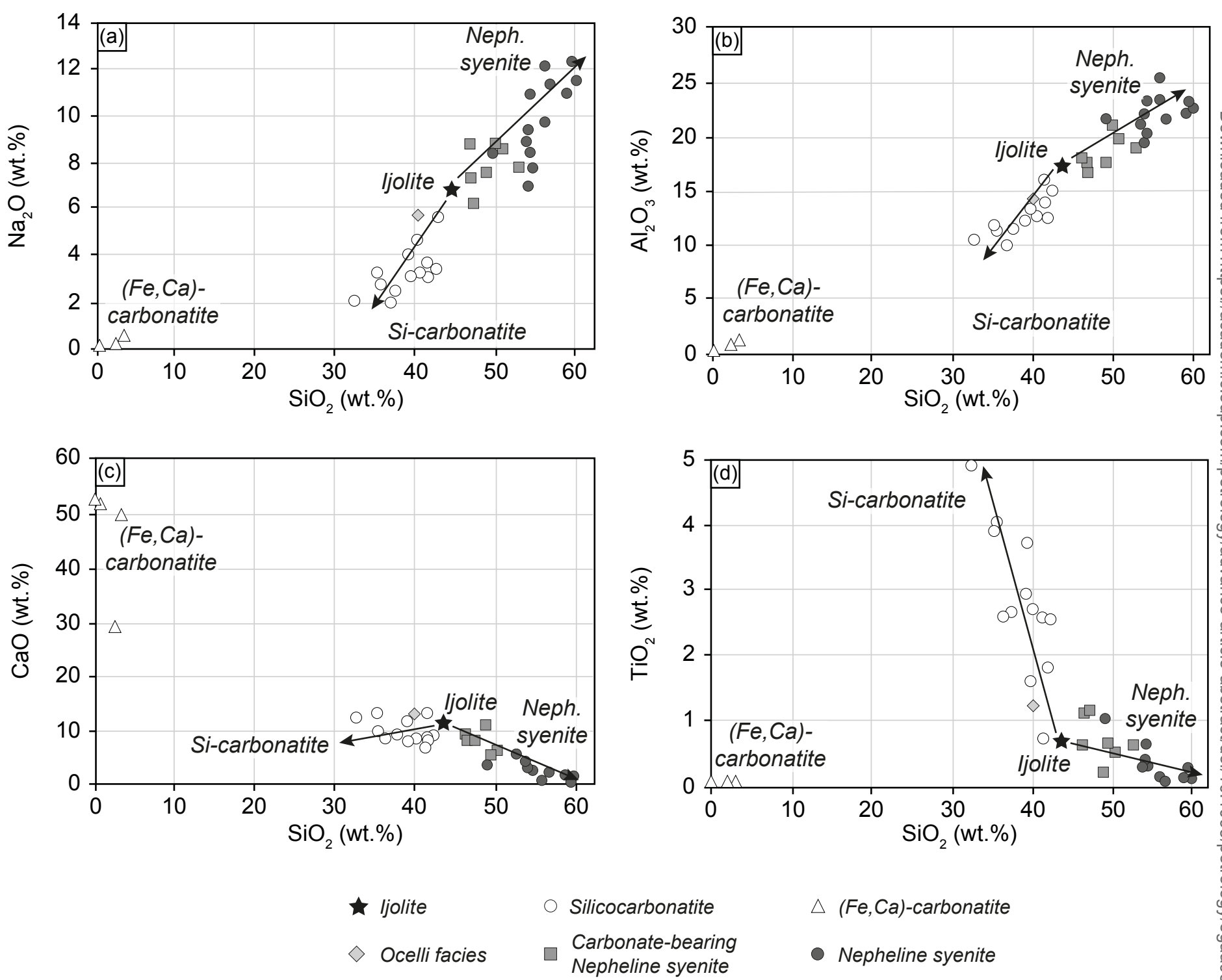

$\triangle(\mathrm{Fe}, \mathrm{Ca})$-carbonatite

- Nepheline syenite 
Figure 7 (black and white; 1 column fitting)
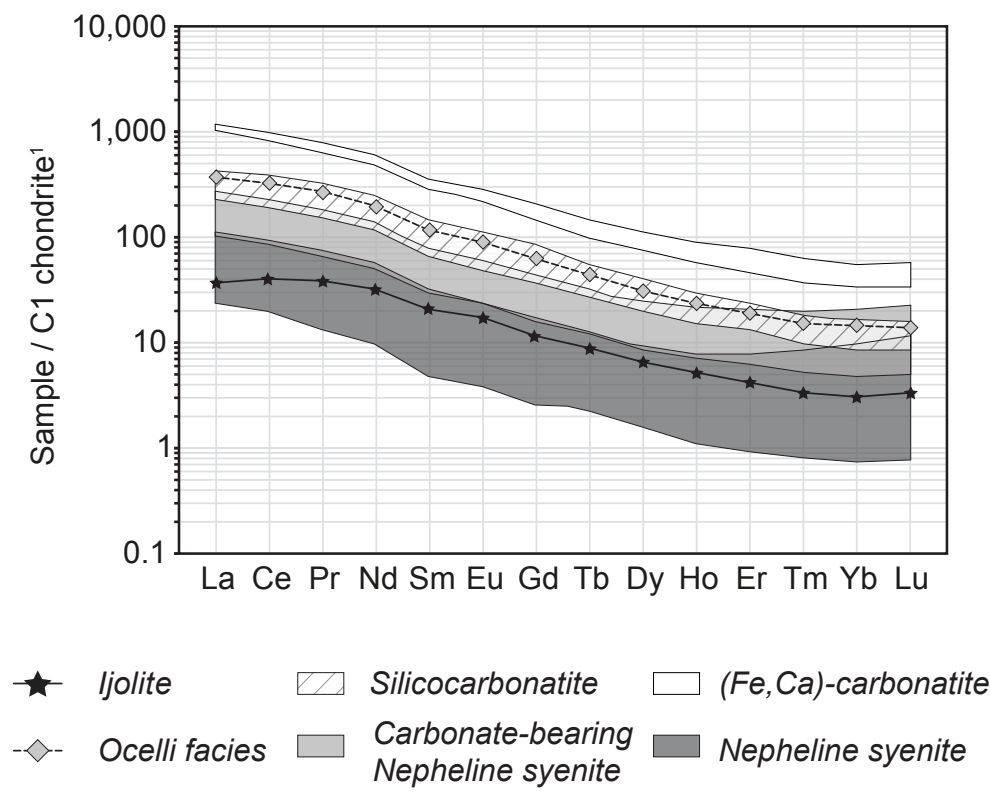
Figure 8 (black and white; 2 columns fitting)
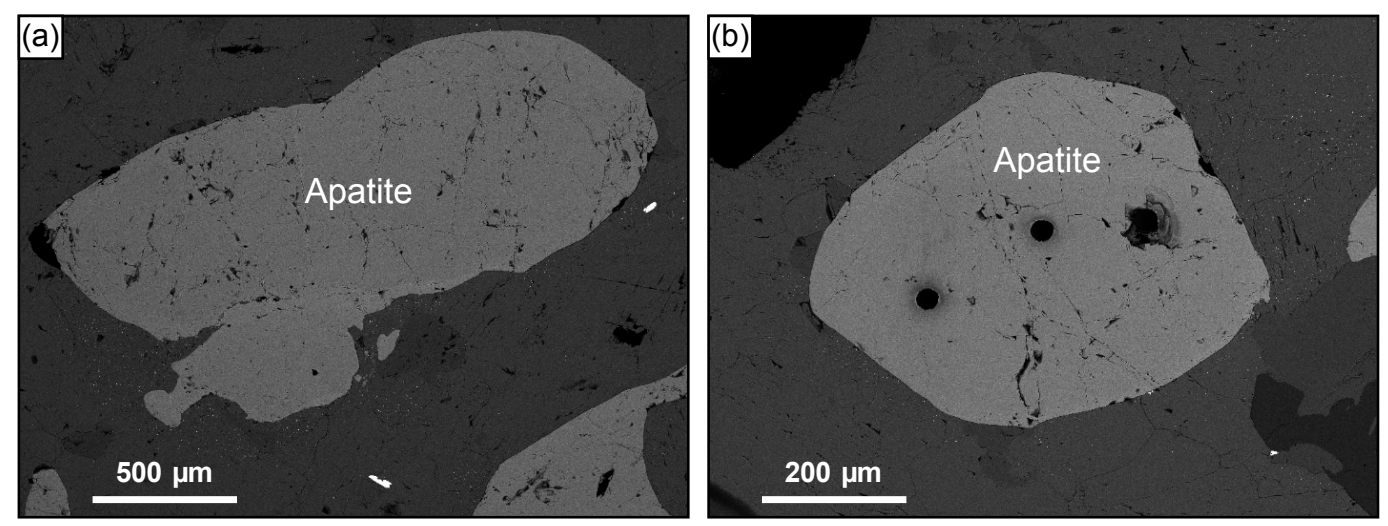

(c)

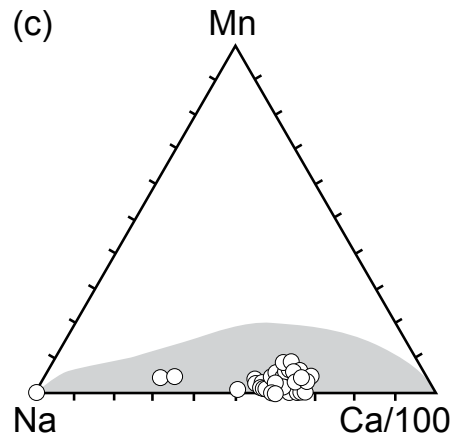

(d)

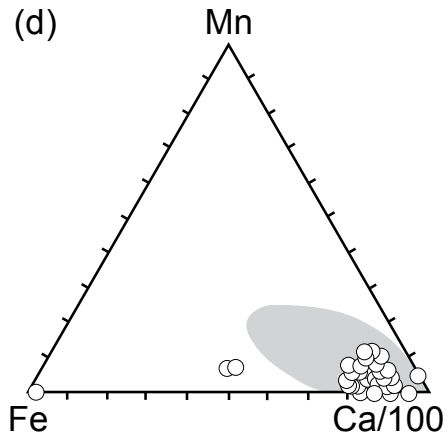

(e)

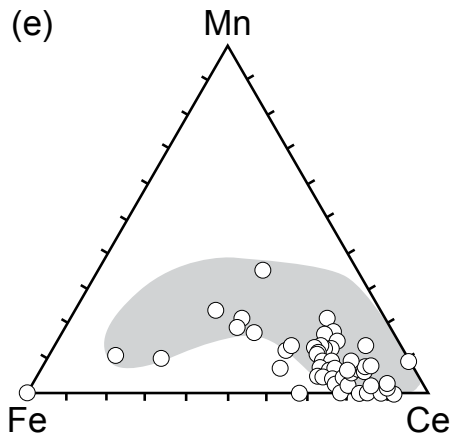

- Apatite from the carbonatite

Compositional field of apatite formed from carbonatitic melts (Piccoli \& Candella, 2002) 
Figure 9 (black and white; 2 columns fitting)
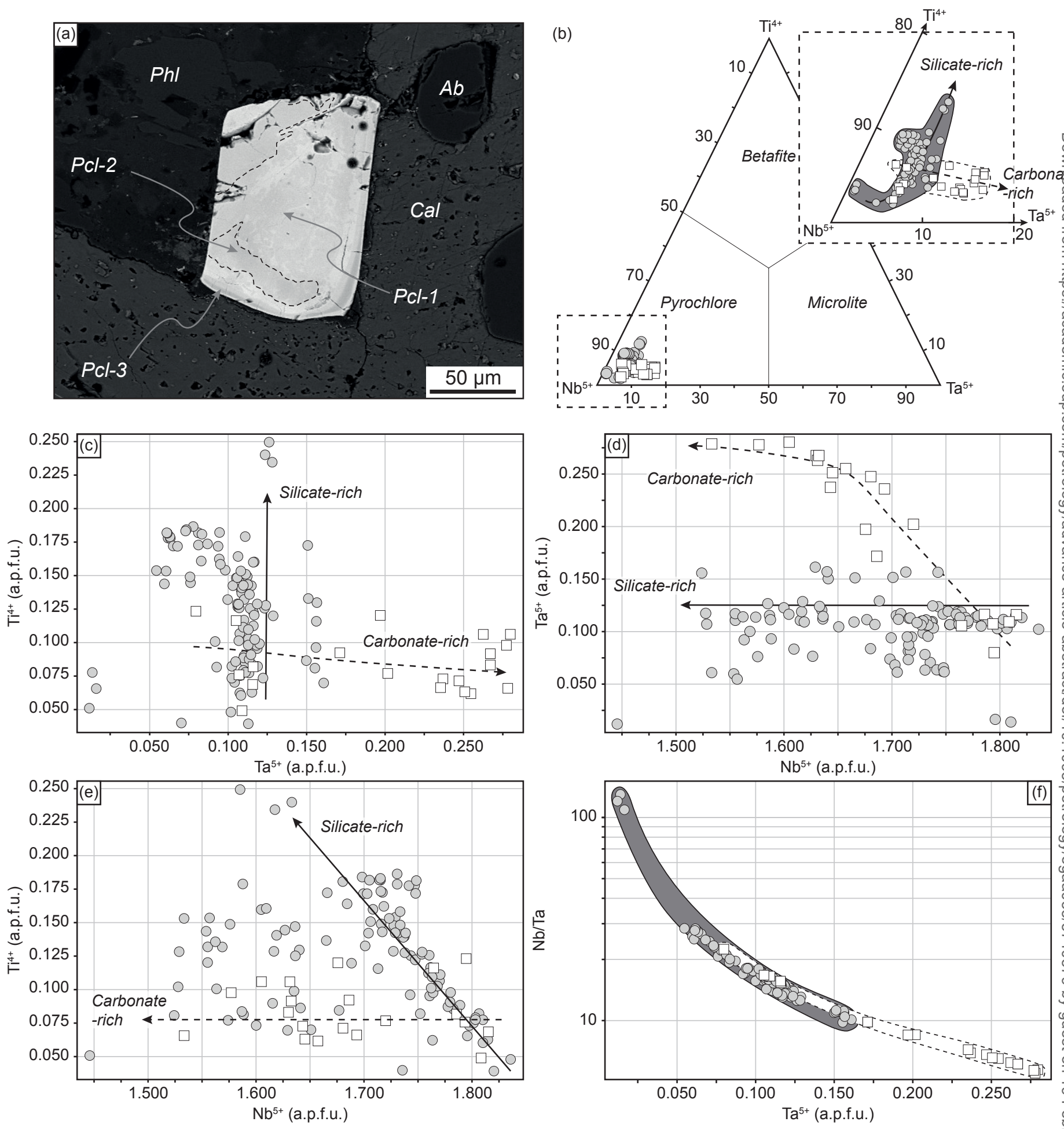

Nepheline syenite

Pyrochlores

Pyrochlores field composition

Ocelli facies

O

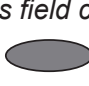

:- . - . 
Figure 10 (color; 2 columns fitting)

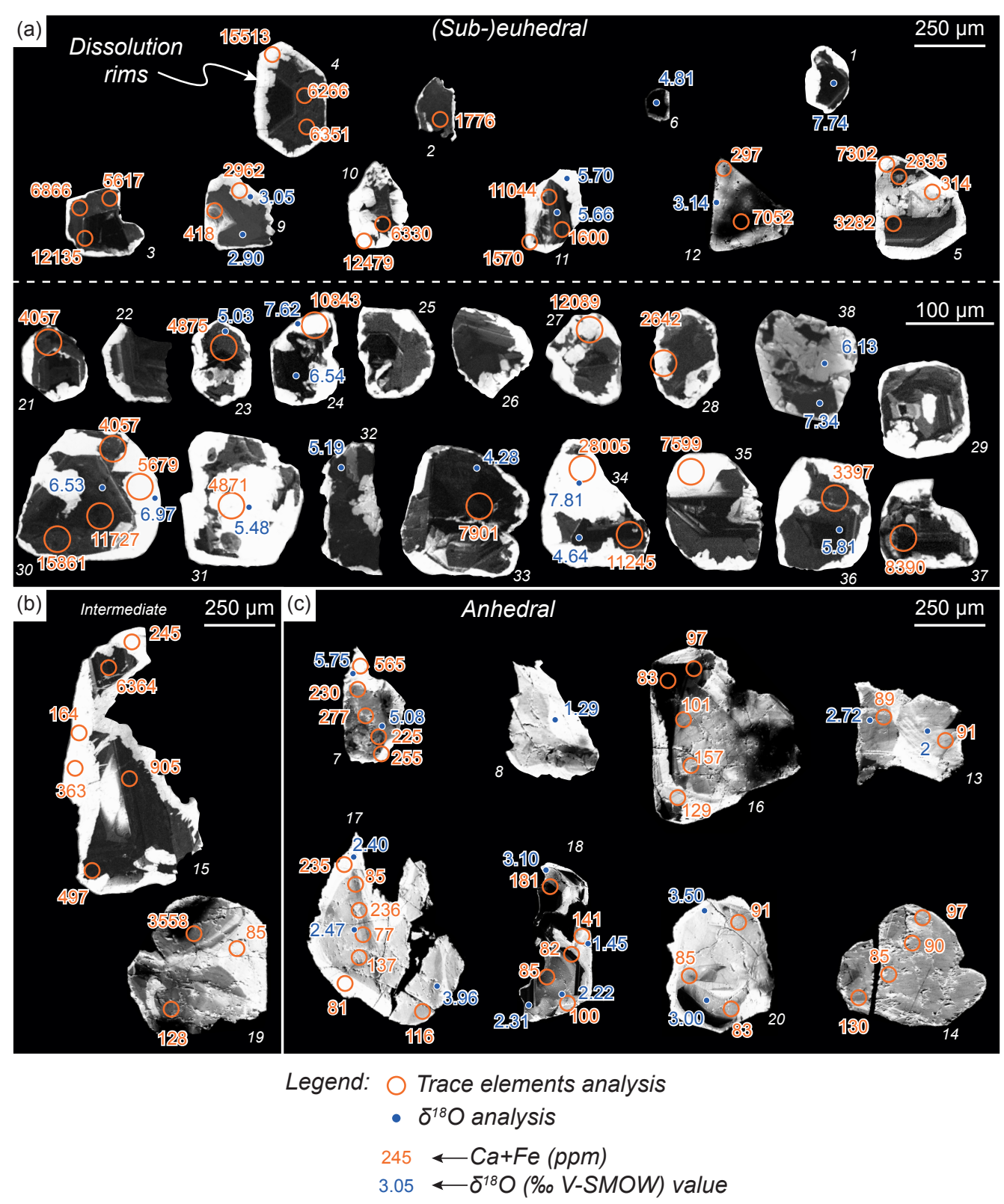


Figure 11 (color; 2 columns fitting)

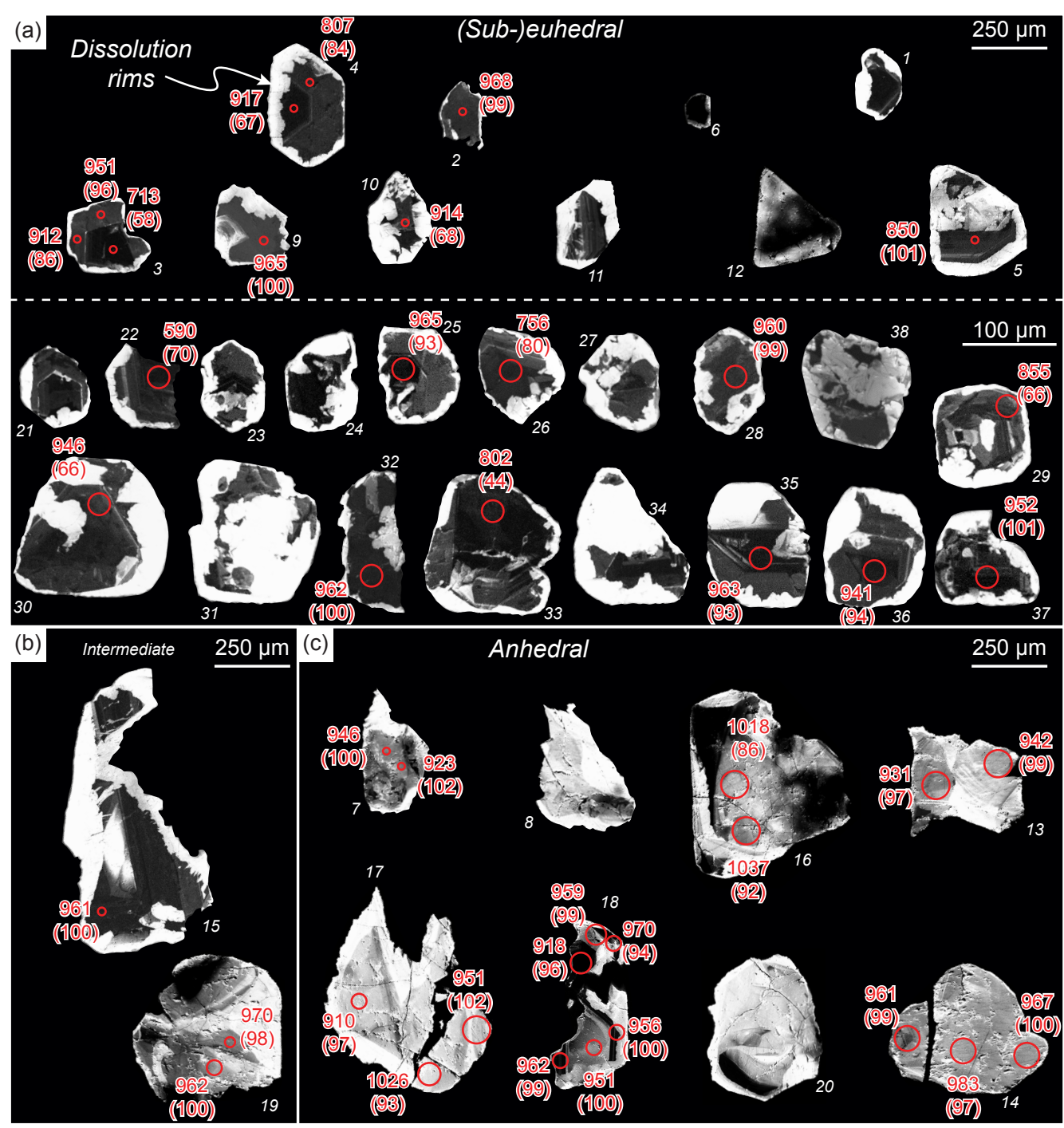

Legend: $\bigcirc \mathrm{U}-\mathrm{Pb}$ analysis

$961{ }^{206} \mathrm{~Pb} /{ }^{207} \mathrm{~Pb}$ age (Ma)

$(100) \longleftarrow$ Degree of concordance (\%) 
Figure 12 (black and white; 2 columns fitting)
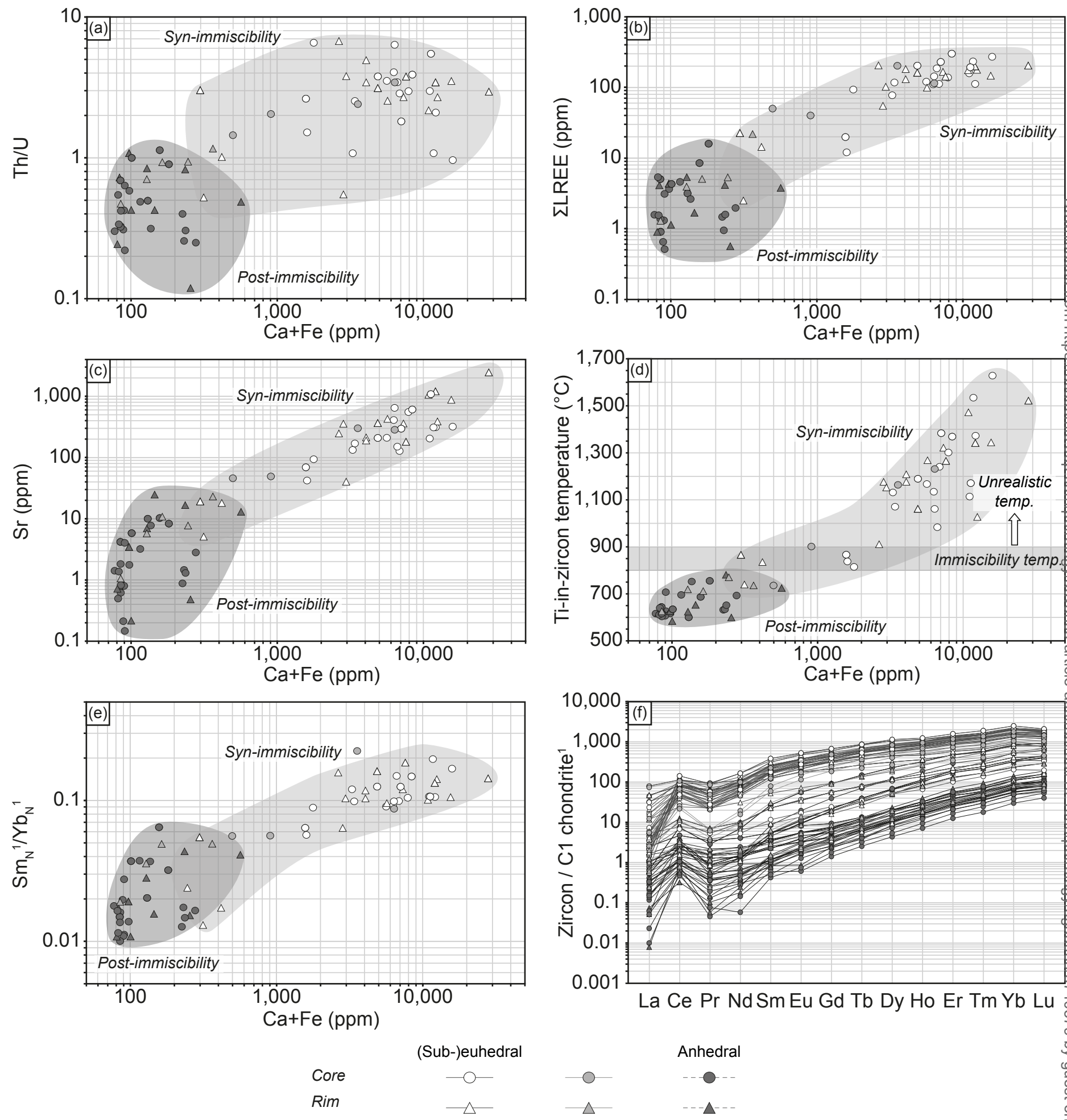
Figure 13 (black and white; 1 column fitting)

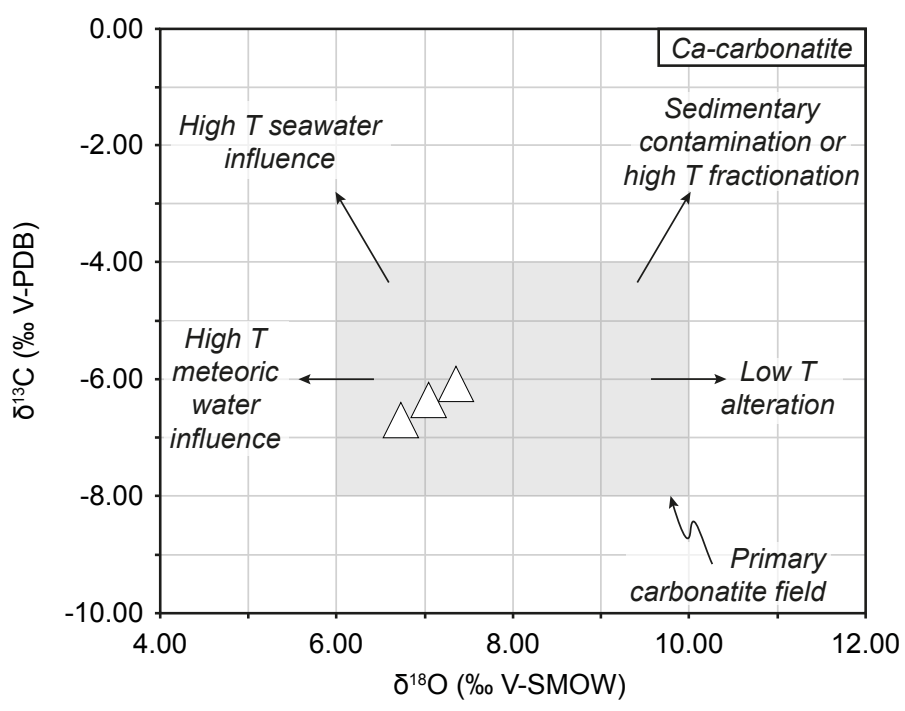

http://www.petrology.oupjournals.org/ 
Figure 14 (black and white; 2 columns fitting)
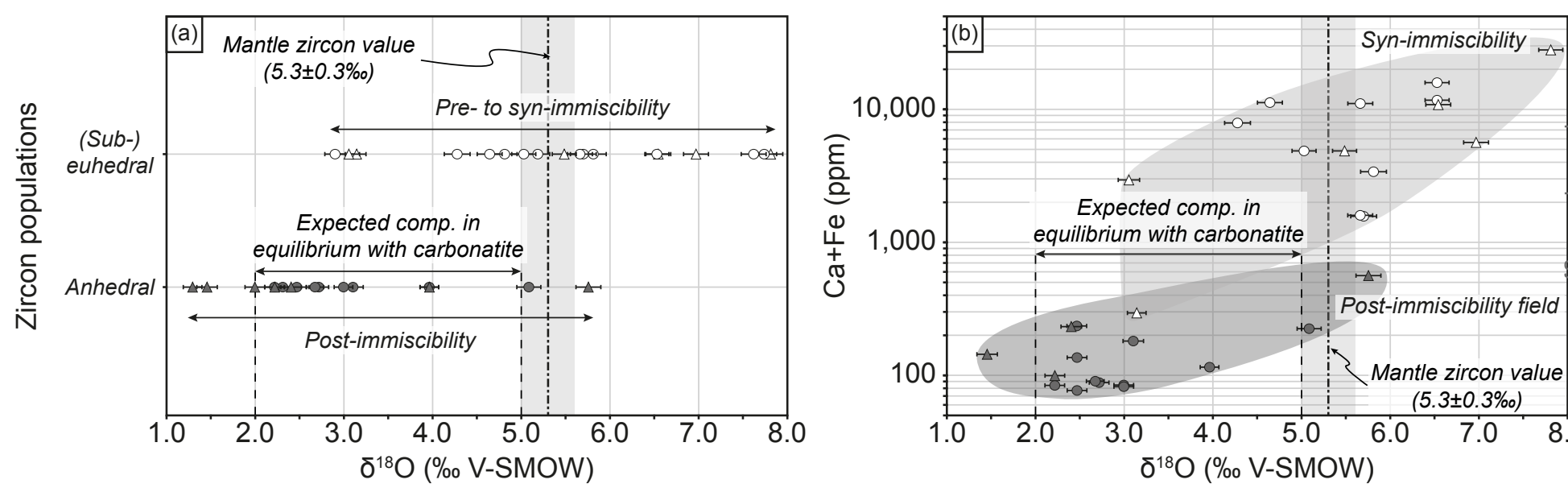

(Sub-)euhedral

Core

$\bigcirc$

Rim

Anhedral

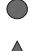


Figure 15 (black and white; 1 column fitting)
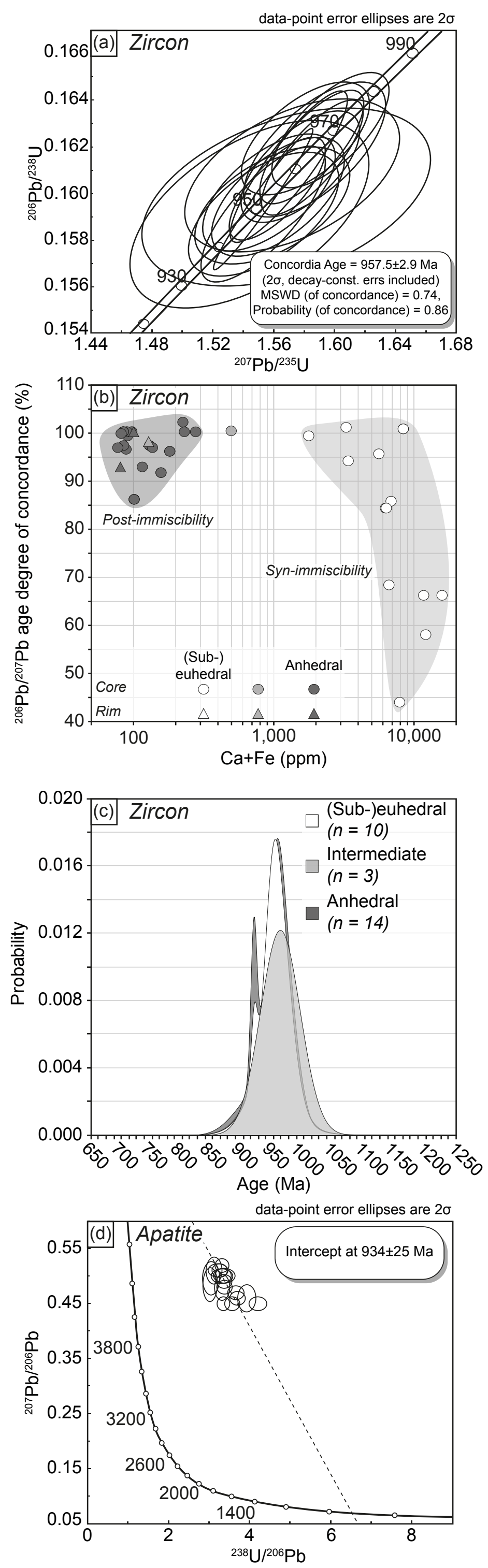
Figure 16 (black and white; 2 columns fitting)

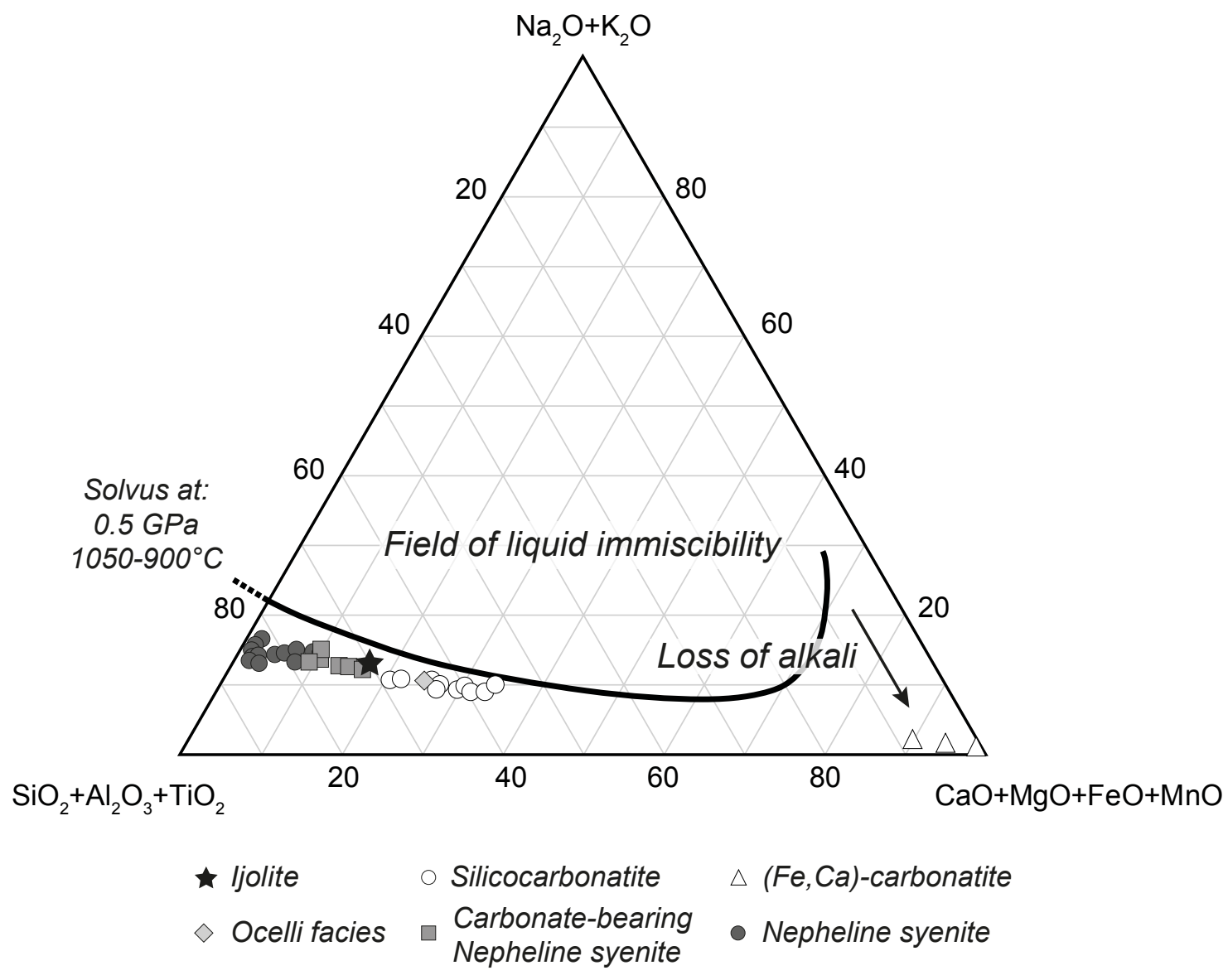


(1) Emplacement of a

ijolitic/urtitic magma

$S$

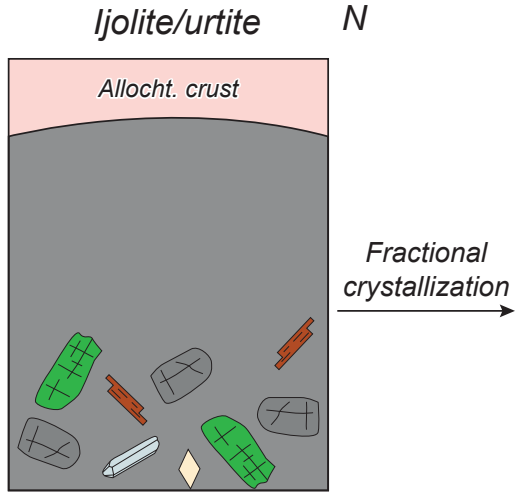

(2) Fractionation of the initial melt and formation of nepheline syenite \pm carbonates

3

Immiscibility between carbonatitic \& silicate liquids Coalescent syenite droplets in a carbonatitic matrix

Nepheline syenite \pm carbonates

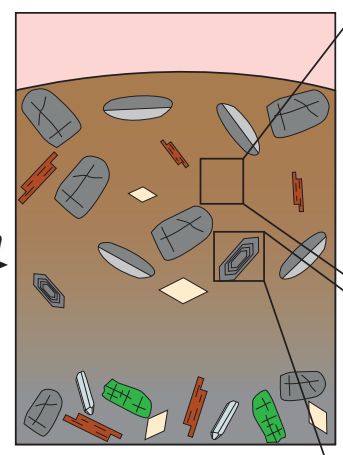

$$
\text { Immiscibility }
$$

Carbonate-bearing Neph. nepheline syenite
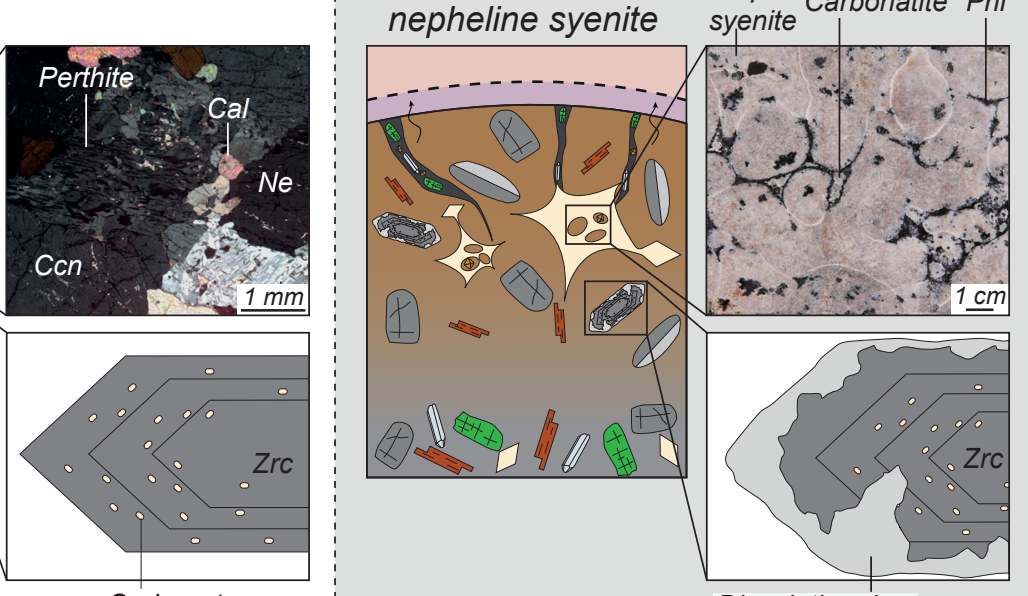

Dissolution rims

(4) Post-immiscibility

Carbonate-free

nepheline syenite \& Neph. Carbonatite $\mathrm{Ph}$ (Fe,Ca)-carbonatite syenite

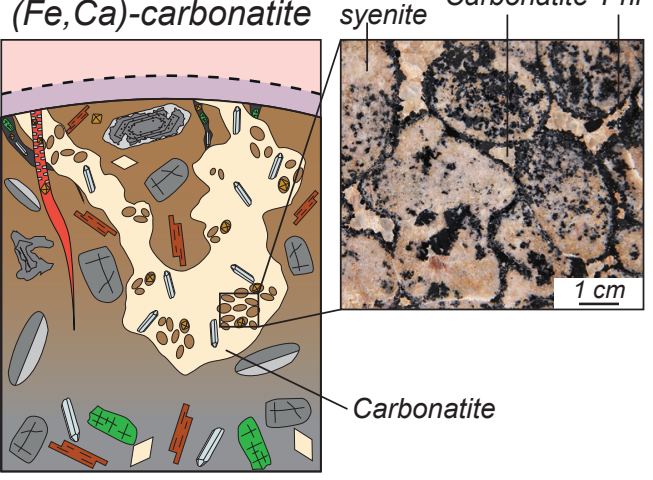

$\sim 90 \%$

Carbonatite

Silicoarbonatite Neph. syen.

Nanoinclusions of carbonates in (sub-)euhedral zircon shifting $\delta^{18} \mathrm{O}_{\mathrm{V} \text {-smow }}$ and $\mathrm{Ca}, \mathrm{Fe}, \mathrm{Sr}$, Ti \& LREE contents?

Dissolution by late-magmatic hydrothermal fluids? Ca-Fe-Sr-Ti-LREE-rich

Pyrochlore in orbicular nepheline syenite and silicocarbonatite - Nb-Ta trend Ta-U-Ca-rich

Minimal temp. $\sim 815-865{ }^{\circ} \mathrm{C}$

Anhedral zircon growth with $\delta^{18} \mathrm{O}_{\mathrm{v}-\mathrm{smow}}$ in equilibirum with carbonatite Ca-Fe-Sr-Ti-LREE-poor

Main Nb-Ta mineralization event

Pyrochlore in pegmatitic nepheline syenite

$$
\begin{aligned}
& \text { - Nb-Ti trend } \\
& \text { Nb-Ti-Th-Na-rich }
\end{aligned}
$$

$800-550{ }^{\circ} \mathrm{C}$ (Ti-in-zircon)

$957.5 \pm 2.9 \mathrm{Ma}$ (zircon)

$934 \pm 25$ Ma (apatite)
$\diamond$ Pyrochlore Apatite ․․․ Pegmatitic nepheline syenite
$\longrightarrow$ Feldspar
Feldspathoids
Nepheline syenite

\section{$\square$ Carbonatite}


Table 1. Present coordinates and results presented in this study of the various facies of the Crevier alkaline intrusion from the central Grenville Province sampled for this study, ordered by outcrop. Abbreviation: $\mathrm{Cb}=$ carbonate; Neph. $=$ nepheline.

\begin{tabular}{|c|c|c|c|c|c|c|c|c|c|c|c|}
\hline \multirow[b]{2}{*}{ Sample $^{1}$} & \multirow[b]{2}{*}{ Easting $^{2}$} & \multirow[b]{2}{*}{ Northing $^{2}$} & \multirow[b]{2}{*}{ Facies } & \multirow[b]{2}{*}{$\begin{array}{l}\text { Whole-rock } \\
\text { geochemistry }^{3}\end{array}$} & \multirow{2}{*}{$\begin{array}{c}\text { Pyrochlore } \\
\text { Mineral } \\
\text { composition }\end{array}$} & \multicolumn{2}{|c|}{ Apatite } & \multicolumn{3}{|c|}{ Zircon } & \multirow[b]{2}{*}{$\begin{array}{c}\mathbf{O}, \mathbf{C} \\
\text { isotopes }^{10}\end{array}$} \\
\hline & & & & & & $\begin{array}{c}\text { Mineral } \\
\text { composition }\end{array}$ & $\underset{\text { dating }}{\text { U-Pb }}$ & $\begin{array}{c}\text { Trace } \\
\text { elements }^{7}\end{array}$ & $\begin{array}{c}\text { U-Pb } \\
\text { dating }^{8}\end{array}$ & $\begin{array}{c}\text { O } \\
\text { isotopes }\end{array}$ & \\
\hline 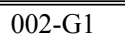 & 661630 & 54581331 & Neph. syenite & & $\overline{\mathrm{x}}$ & & & & & & \\
\hline $004-\mathrm{C} 1$ & 661307 & 5481637 & Neph. syenite & $\mathrm{x}$ & & & & & & & \\
\hline $004-\mathrm{C} 2$ & & & Neph. syenite & $\mathrm{x}$ & $\mathrm{x}$ & & & & & & \\
\hline $006-\mathrm{C} 2$ & 661278 & 5481665 & Neph. syenite & & $\mathrm{x}$ & & & & & & \\
\hline $006-\mathrm{C} 3$ & & & Neph. syenite & $\mathrm{x}$ & $\mathrm{x}$ & & & & & & \\
\hline $007-\mathrm{A} 6$ & 661230 & 5481797 & Carbonatite & & & $\mathrm{x}$ & $\mathrm{x}$ & $\mathrm{x}$ & & & $\mathrm{x}$ \\
\hline 007-B1 & & & Neph. syenite & $\mathrm{x}$ & & & & & & & \\
\hline 007-D1 & & & Ijolite & $\mathrm{x}$ & & & & & & & \\
\hline 007-E1 & & & Silicocarbonatite & $\mathrm{x}$ & & & & & & & \\
\hline 007-E4 & & & Silicocarbonatite & $\mathrm{x}$ & & & & & & & \\
\hline 007-E8 & & & Silicocarbonatite & $\mathrm{x}$ & & & & & & & \\
\hline 007-E10 & & & Cb-bearing Neph. syenite & $\mathrm{x}$ & & & & & & & \\
\hline 008-A1 & 662009 & 5481013 & Carbonatite & $\mathrm{x}$ & & & & & & & \\
\hline 008-B1 & & & Neph. syenite & $\mathrm{x}$ & & & & & & & \\
\hline 008-B4 & & & Silicocarbonatite & $\mathrm{x}$ & & & & & & & \\
\hline $008-\mathrm{C} 1$ & & & Cb-bearing Neph. syenite & $\mathrm{x}$ & & & & & & & \\
\hline 008-D1 & & & Cb-bearing Neph. syenite & $\mathrm{x}$ & & & & & & & \\
\hline 008-E2 & & & Silicocarbonatite & $\mathrm{x}$ & & & & & & & \\
\hline 008-E3 & & & Cb-bearing Neph. syenite & $\mathrm{x}$ & & & & & & & \\
\hline $009-\mathrm{A} 2$ & 658768 & 5484886 & Carbonatite & $\mathrm{x}$ & & & & & & & \\
\hline 009-A5 & & & Carbonatite & $\mathrm{x}$ & & & & & & & $\mathrm{x}$ \\
\hline $009-\mathrm{B} 2$ & & & Cb-bearing Neph. syenite & $\mathrm{x}$ & & & & & & & \\
\hline 009-D1 & & & Silicocarbonatite & $\mathrm{x}$ & & & & & & & \\
\hline 009-D2 & & & Silicocarbonatite & $\mathrm{x}$ & & & & & & & \\
\hline 009-E6 & & & Silicocarbonatite & $\mathrm{x}$ & & & & & & & \\
\hline 009-E8 & & & Silicocarbonatite & $\mathrm{x}$ & & & & & & & \\
\hline $010-\mathrm{D} 1$ & 662126 & 5480819 & Silicocarbonatite & $\mathrm{x}$ & & & & & & & \\
\hline 010-D2 & & & Neph. syenite & $\mathrm{x}$ & & & & & & & \\
\hline $010-\mathrm{G}$ & & & Ocelli facies & $\mathrm{x}$ & & & & & & & \\
\hline 010-G1 & & & Ocelli facies & $\mathrm{x}$ & $\mathrm{x}$ & & & & & & \\
\hline $010-\mathrm{G} 2$ & & & Ocelli facies & & $\mathrm{x}$ & & & & & & \\
\hline 011-B1 & 662159 & 5480785 & Neph. syenite & $\mathrm{x}$ & & & & $\mathrm{x}$ & $\mathrm{x}$ & $\mathrm{x}$ & \\
\hline 011-B2 & & & Neph. syenite & $\mathrm{x}$ & & & & & & & \\
\hline 011-B3 & & & Cb-bearing Neph. syenite & $\mathrm{x}$ & & & & & & & \\
\hline $011-\mathrm{G} 1$ & & & Neph. syenite & x & & & & & & & \\
\hline $012-\mathrm{G}$ & 661313 & 5481636 & Neph. syenite & $\mathrm{x}$ & & & & & & & \\
\hline $012-\mathrm{G} 2$ & & & Cb-bearing Neph. syenite & $\mathrm{x}$ & & & & & & & \\
\hline 012-G3 & & & Neph. syenite & & & & & & & & \\
\hline
\end{tabular}




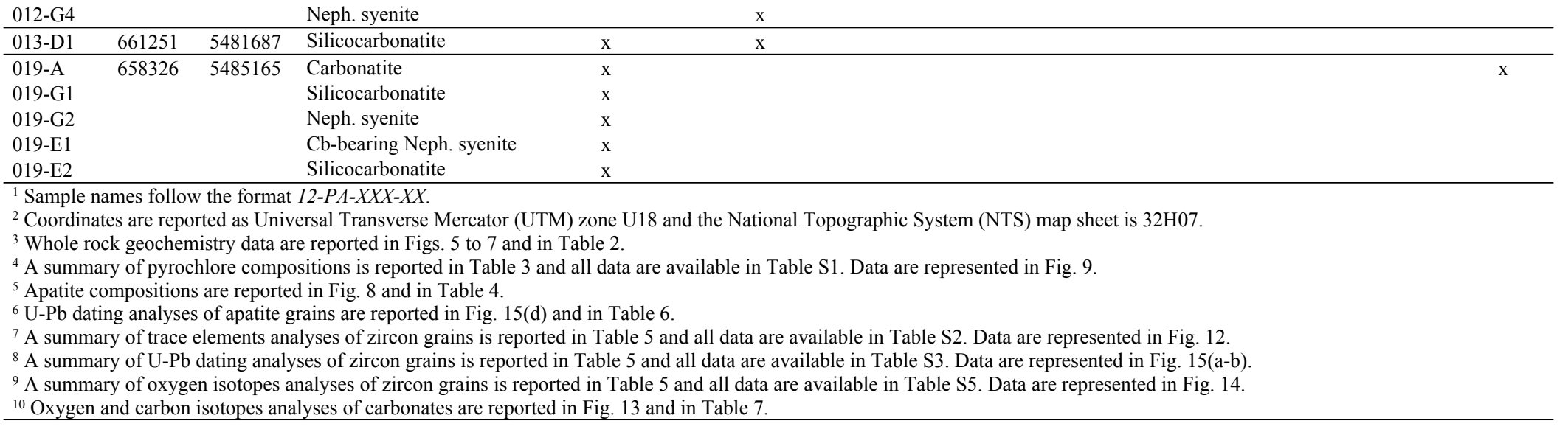


Table 2. Whole-rock geochemistry of the plutonic rocks from the various facies identified in the Crevier alkaline intrusion from the central Grenville Province, ordered by rock type. Abbreviations: $\mathrm{C}=(\mathrm{Fe}, \mathrm{Ca})$-carbonatite; $\mathrm{Cb}$-bearing $\mathrm{NS}=$ carbonate-bearing nepheline syenite; $\mathrm{LOI}=$ loss on ignition; $\mathrm{Mg} \#=(\mathrm{Mg}) /(\mathrm{Mg}+\mathrm{Fe}) ; \mathrm{NS}=$ nepheline syenite; $\mathrm{SC}=$ Silicocarbonatite.

\begin{tabular}{|c|c|c|c|c|c|c|c|c|c|c|c|c|c|c|}
\hline $\begin{array}{l}\text { Facies } \\
\text { Sample }^{1}\end{array}$ & $\begin{array}{c}\mathrm{C} \\
009-\mathrm{A} 2 \\
\end{array}$ & $\begin{array}{c}C \\
009-A 5 \\
\end{array}$ & $\begin{array}{c}\mathrm{C} \\
008-\mathrm{A} 1 \\
\end{array}$ & $\begin{array}{c}C \\
019-A \\
\end{array}$ & $\begin{array}{c}\text { SC } \\
\text { 007-E1 }\end{array}$ & $\begin{array}{c}\text { SC } \\
019-E 2 \\
\end{array}$ & $\begin{array}{c}\text { SC } \\
\text { 007-E4 }\end{array}$ & $\begin{array}{c}\text { SC } \\
\text { 007-E8 }\end{array}$ & $\begin{array}{c}\text { SC } \\
008-E 2\end{array}$ & $\begin{array}{c}\text { SC } \\
\text { 008-B4 }\end{array}$ & $\begin{array}{c}\text { SC } \\
\text { 009-D1 }\end{array}$ & $\begin{array}{c}\text { SC } \\
\text { 009-E6 }\end{array}$ & $\begin{array}{c}\text { SC } \\
\text { 013-D1 }\end{array}$ & $\begin{array}{c}\mathrm{SC} \\
009-\mathrm{D} 2\end{array}$ \\
\hline $\mathrm{SiO}_{2}(w t . \%)$ & 3.20 & 0.34 & 2.34 & 0.16 & 35.31 & 35.69 & 39.95 & 36.76 & 41.98 & 32.52 & 40.19 & 39.30 & 39.57 & 37.49 \\
\hline $\mathbf{A l}_{2} \mathbf{O}_{3}$ & 1.22 & 0.11 & 0.72 & 0.05 & 11.57 & 11.36 & 14.06 & 10.18 & 12.65 & 10.69 & 12.67 & 12.23 & 13.14 & 11.53 \\
\hline $\mathrm{Fe}_{2} \mathrm{O}_{3(\mathrm{~T})}$ & 1.53 & 1.70 & 35.13 & 1.18 & 14.80 & 15.57 & 9.79 & 16.43 & 13.78 & 14.31 & 12.52 & 11.98 & 16.39 & 13.86 \\
\hline $\mathrm{FeO}$ & 1.24 & 1.39 & 31.79 & 0.93 & 9.75 & 10.35 & 7.34 & 12.46 & 10.77 & 8.42 & 8.80 & 8.10 & 11.39 & 10.06 \\
\hline $\mathrm{Fe}_{2} \mathrm{O}_{3}$ & 0.16 & 0.17 & 0.16 & 0.15 & 4.07 & 4.18 & 1.72 & 2.72 & 1.94 & 5.05 & 2.84 & 3.07 & 3.86 & 2.79 \\
\hline MgO & 0.64 & 0.55 & 0.65 & 0.41 & 4.27 & 5.34 & 2.51 & 9.36 & 3.95 & 6.71 & 7.00 & 4.05 & 4.51 & 7.59 \\
\hline MnO & 0.37 & 0.29 & 0.27 & 0.32 & 0.22 & 0.22 & 0.18 & 0.20 & 0.23 & 0.24 & 0.17 & 0.19 & 0.14 & 0.17 \\
\hline $\mathrm{CaO}$ & 49.73 & 51.78 & 28.29 & 52.44 & 12.44 & 9.34 & 12.28 & 8.18 & 8.27 & 12.05 & 7.89 & 11.05 & 7.59 & 8.42 \\
\hline $\mathrm{Na}_{2} \mathrm{O}$ & 0.58 & 0.09 & 0.12 & 0.07 & 3.22 & 2.72 & 4.83 & 2.19 & 3.46 & 2.10 & 3.49 & 4.01 & 3.38 & 2.63 \\
\hline $\mathbf{K}_{2} \mathbf{O}$ & 0.24 & 0.03 & 0.43 & 0.01 & 4.55 & 5.25 & 4.56 & 6.72 & 5.58 & 5.59 & 5.60 & 4.08 & 5.37 & 5.96 \\
\hline $\mathrm{TiO}_{2}$ & 0.01 & 0.02 & 0.01 & 0.00 & 3.92 & 4.03 & 1.57 & 2.57 & 1.79 & 4.90 & 2.69 & 2.92 & 3.71 & 2.64 \\
\hline $\mathbf{P}_{2} \mathbf{O}_{5}$ & 0.06 & 0.05 & 5.84 & 0.31 & 2.42 & 1.03 & 1.93 & 1.23 & 0.64 & 1.63 & 1.18 & 1.33 & 5.64 & 1.27 \\
\hline $\mathrm{Cr}_{2} \mathrm{O}_{3}$ & $<0.01$ & $<0.01$ & $<0.01$ & $<0.01$ & $<0.01$ & 0.02 & $<0.01$ & 0.05 & 0.02 & 0.02 & 0.04 & $<0.01$ & $<0.01$ & 0.03 \\
\hline LOI & 40.23 & 42.00 & 40.62 & 42.07 & 7.68 & 6.95 & 8.38 & 6.07 & 6.56 & 8.69 & 6.05 & 8.16 & 0.58 & 6.20 \\
\hline Total & 97.82 & 96.96 & 69.18 & 97.01 & 100.40 & 97.50 & 100.00 & 99.89 & 98.88 & 99.43 & 99.45 & 99.30 & 100.00 & 97.77 \\
\hline Sr (ppm) & 8714 & 8722 & 4152 & 9343 & 1929 & 1600 & 2736 & 1343 & 1328 & 1511 & 1251 & 1845 & 868 & 1316 \\
\hline $\mathbf{B a}$ & 361 & 403 & 298 & 360 & 686 & 716 & 1118 & 506 & 566 & 437 & 780 & 465 & 328 & 545 \\
\hline Nb & 17 & 7.2 & 2.3 & 12 & 391 & 334 & 138 & 216 & 210 & 565 & 301 & 481 & 921 & 282 \\
\hline Ta & 3.9 & 0.4 & 0.0 & 0.4 & 48 & 32 & 9.5 & 15 & 15 & 54 & 21 & 22 & 140 & 28 \\
\hline $\mathbf{W}$ & 0.8 & $<0.5$ & 3.6 & $<0.5$ & $<0.5$ & $<0.5$ & $<0.5$ & $<0.5$ & $<0.5$ & $<0.5$ & 0.7 & $<0.5$ & $<0.5$ & $<0.5$ \\
\hline $\mathbf{T I}$ & $<0.05$ & $<0.05$ & 0.1 & $<0.05$ & 0.3 & 0.3 & 0.2 & 0.5 & 0.5 & 0.7 & 0.4 & 0.4 & 0.8 & 0.6 \\
\hline $\mathbf{B i}$ & $<0.1$ & $<0.1$ & 0.1 & $<0.1$ & $<0.1$ & $<0.1$ & $<0.1$ & $<0.1$ & $<0.1$ & $<0.1$ & $<0.1$ & $<0.1$ & $<0.1$ & $<0.1$ \\
\hline Th & 3.8 & 0.5 & 6.3 & 0.6 & 3.7 & 0.6 & 3.1 & 2.3 & 1.4 & 0.9 & 5.9 & 1.1 & 16 & 3.9 \\
\hline $\mathbf{U}$ & 0.8 & 0.3 & 1.3 & 0.1 & 1.0 & 0.7 & 1.7 & 0.4 & 0.4 & 1.0 & 0.6 & 0.1 & 12 & 1.2 \\
\hline $\mathbf{V}$ & 7.0 & 5.0 & 6.0 & 7.0 & 268 & 289 & 131 & 281 & 119 & 318 & 234 & 178 & 215 & 221 \\
\hline $\mathbf{R b}$ & 4.0 & $<1$ & 7.0 & $<1$ & 119 & 143 & 81 & 139 & 289 & 270 & 153 & 142 & 360 & 201 \\
\hline $\mathbf{Y}$ & 123 & 114 & 79 & 135 & 41 & 25 & 34 & 22 & 23 & 27 & 26 & 27 & 33 & 25 \\
\hline $\mathbf{Z r}$ & 121 & 4.0 & 4.0 & 2.0 & 627 & 408 & 549 & 412 & 199 & 292 & 637 & 52 & 621 & 393 \\
\hline La & 245 & 248 & 261 & 288 & 95 & 63 & 79 & 53 & 55 & 69 & 67 & 65 & 100 & 64 \\
\hline $\mathrm{Ce}$ & 509 & 510 & 542 & 598 & 226 & 138 & 179 & 118 & 121 & 151 & 140 & 141 & 237 & 140 \\
\hline Pr & 61 & 62 & 65 & 75 & 28 & 16 & 22 & 14 & 14 & 18 & 17 & 17 & 30 & 17 \\
\hline Nd & 228 & 234 & 250 & 280 & 115 & 63 & 87 & 56 & 54 & 70 & 66 & 64 & 117 & 64 \\
\hline Sm & 43 & 43 & 44 & 54 & 22 & 12 & 16 & 11 & 10 & 13 & 11 & 12 & 21 & 12 \\
\hline Eu & 13 & 13 & 12 & 16 & 6.3 & 3.5 & 4.8 & 3.1 & 2.7 & 3.6 & 3.4 & 3.5 & 5.8 & 3.4 \\
\hline Gd & 35 & 34 & 29 & 41 & 17 & 9.0 & 12 & 8.1 & 7.4 & 9.6 & 8.8 & 9.1 & 15 & 9.1 \\
\hline $\mathbf{T b}$ & 4.7 & 4.6 & 3.6 & 5.4 & 2.0 & 1.2 & 1.6 & 1.0 & 1.0 & 1.2 & 1.1 & 1.1 & 1.8 & 1.1 \\
\hline Dy & 24 & 23 & 18 & 28 & 10 & 5.5 & 7.7 & 4.8 & 4.9 & 5.9 & 5.7 & 5.8 & 8.4 & 5.5 \\
\hline Но & 4.4 & 4.2 & 3.2 & 4.9 & 1.6 & 1.0 & 1.3 & 0.8 & 0.9 & 1.0 & 1.0 & 1.0 & 1.3 & 0.9 \\
\hline $\mathbf{E r}$ & 12 & 10 & 7.5 & 12 & 3.8 & 2.4 & 3.0 & 2.1 & 2.3 & 2.5 & 2.5 & 2.5 & 3.1 & 2.3 \\
\hline $\mathbf{T m}$ & 1.4 & 1.4 & 0.9 & 1.6 & 0.4 & 0.3 & 0.4 & 0.3 & 0.3 & 0.3 & 0.3 & 0.3 & 0.3 & 0.3 \\
\hline $\mathbf{Y b}$ & 8.7 & 8.4 & 5.5 & 9.0 & 2.6 & 1.7 & 2.1 & 1.4 & 1.9 & 1.9 & 1.9 & 1.8 & 1.8 & 1.7 \\
\hline Lu & 1.3 & 1.3 & 0.8 & 1.4 & 0.4 & 0.3 & 0.3 & 0.2 & 0.3 & 0.3 & 0.3 & 0.3 & 0.2 & 0.3 \\
\hline ¿REE & 1189 & 1197 & 1243 & 1414 & 530 & 317 & 416 & 274 & 275 & 347 & 326 & 1189 & 1197 & 1243 \\
\hline$[\mathbf{L a} / \mathbf{Y b}]_{\mathbf{N}}$ & 19 & 20 & 32 & 22 & 25 & 25 & 25 & 25 & 20 & 25 & 24 & 19 & 20 & 32 \\
\hline$[\mathbf{G d} / \mathbf{Y b}]_{\mathbf{N}}$ & 3.2 & 3.3 & 4.3 & 3.7 & 5.3 & 4.3 & 4.7 & 4.6 & 3.2 & 4.0 & 3.7 & 4.1 & 6.6 & 4.4 \\
\hline Cl & 0.0 & 0.1 & 0.0 & 0.0 & $<0.01$ & 0.0 & 0.0 & 0.0 & 0.0 & $<0.01$ & 0.0 & 0.0 & 0.0 & $<0.01$ \\
\hline $\mathbf{F}$ & $<0.01$ & $<0.01$ & 0.4 & 0.0 & 0.2 & 0.2 & 0.1 & 0.3 & 0.2 & 0.3 & 0.2 & 0.2 & 0.4 & 0.3 \\
\hline $\mathrm{Cu}$ & $<1$ & 12 & 57 & 4.0 & 10 & 2.0 & 9.0 & $<1$ & $<1$ & $<1$ & $<1$ & 4.0 & $<1$ & 5.0 \\
\hline $\mathbf{N i}$ & $<1$ & 3.0 & 27 & $<1$ & 18 & 41 & 6.0 & 255 & 42 & 37 & 118 & 12 & 10 & 157 \\
\hline Мo & 3.0 & 1.0 & 104 & $<1$ & $<1$ & $<1$ & $<1$ & $<1$ & $<1$ & $<1$ & $<1$ & $<1$ & $<1$ & $<1$ \\
\hline Zn & 5.0 & 5.0 & 12 & 5.0 & 151 & 217 & 138 & 212 & 270 & 246 & 160 & 180 & 44 & 184 \\
\hline $\mathbf{S}$ & 1600 & 2400 & 43100 & 1800 & 400 & 400 & 500 & 300 & 300 & 500 & 300 & 400 & 300 & 1400 \\
\hline Au & $<2$ & $<2$ & 5.0 & $<2$ & 6.0 & $<2$ & 11 & $<2$ & 8.0 & $<2$ & $<2$ & 4.0 & $<2$ & $<2$ \\
\hline Ag & 0.6 & $<0.5$ & $<0.5$ & $<0.5$ & 3.3 & 2.1 & 2.9 & 2.1 & 1.0 & 1.4 & 2.9 & $<0.5$ & 3.0 & 2.0 \\
\hline As & $<0.5$ & $<0.5$ & 1.5 & $<0.5$ & $<0.5$ & 1.3 & $<0.5$ & $<0.5$ & $<0.5$ & $<0.5$ & $<0.5$ & 1.1 & $<0.5$ & $<0.5$ \\
\hline $\mathrm{Br}$ & 2.8 & $<0.5$ & $<0.5$ & $<0.5$ & $<0.5$ & $<0.5$ & 3.4 & $<0.5$ & 3.0 & 4.4 & $<0.5$ & $<0.5$ & $<0.5$ & $<0.5$ \\
\hline $\mathrm{Cr}$ & 11 & 5.0 & $<5$ & $<5$ & 14 & 125 & $<5$ & 268 & 106 & 111 & 204 & 10 & 9.0 & 198 \\
\hline Sc & 5.8 & 4.0 & 5.8 & 1.7 & 5.6 & 6.4 & 2.1 & 23 & 6.0 & 4.9 & 9.5 & 3.4 & 3.4 & 6.0 \\
\hline Sb & $<0.1$ & 0.3 & $<0.1$ & $<0.1$ & $<0.1$ & $<0.1$ & $<0.1$ & $<0.1$ & $<0.1$ & $<0.1$ & $<0.1$ & 0.4 & $<0.1$ & $<0.1$ \\
\hline $\mathrm{Se}$ & $<3$ & $<3$ & $<3$ & $<3$ & $<3$ & $<3$ & $<3$ & $<3$ & $<3$ & $<3$ & $<3$ & $<3$ & $<3$ & $<3$ \\
\hline Co & $<1$ & $<1$ & 57 & $<1$ & 26 & 32 & 13 & 50 & 22 & 18 & 36 & 25 & 23 & 42 \\
\hline Ga & 6.0 & 4.0 & 5.0 & 4.0 & 36 & 36 & 31 & 28 & 32 & 50 & 31 & 36 & 50 & 34 \\
\hline Ge & 1.0 & 0.9 & 1.0 & 1.1 & 2.4 & 1.8 & 1.4 & 1.9 & 1.8 & 1.9 & 1.8 & 1.9 & 2.7 & 1.8 \\
\hline Sn & $<1$ & $<1$ & $<1$ & $<1$ & 5.0 & 4.0 & 3.0 & 12 & 3.0 & 5.0 & 5.0 & 4.0 & 4.0 & 3.0 \\
\hline Cs & 0.1 & $<0.1$ & $<0.1$ & $<0.1$ & 2.3 & 2.8 & 1.4 & 3.7 & 4.4 & 7.8 & 4.3 & 3.3 & 7.5 & 4.7 \\
\hline $\mathbf{P b}$ & 16 & 14 & 7.0 & 10 & 4.0 & $<3$ & 4.0 & $<3$ & $<3$ & 5.0 & $<3$ & 7.0 & 6.0 & 7.0 \\
\hline $\mathrm{Be}$ & $<1$ & $<1$ & $<1$ & $<1$ & 2.0 & 2.0 & 2.0 & 7.0 & 2.0 & 1.0 & 5.0 & 2.0 & 2.0 & 5.0 \\
\hline Hf & 3.5 & 0.3 & 0.1 & 0.3 & 14 & 7.8 & 9.0 & 8.8 & 4.0 & 5.4 & 12 & 1.0 & 9.1 & 7.1 \\
\hline
\end{tabular}




\begin{tabular}{|c|c|c|c|c|c|c|c|c|c|c|c|c|c|c|}
\hline Mg\# & 48 & 41 & 4 & 44 & 44 & 48 & 38 & 57 & 40 & 59 & 59 & 47 & 41 & 57 \\
\hline
\end{tabular}

\begin{tabular}{|c|c|c|c|c|c|c|c|c|c|c|c|c|c|}
\hline Sample & 009-E8 & 010-D1 & 019-G1 & $\begin{array}{c}\text { Ocelli } \\
\text { facies } \\
\text { 010-G }\end{array}$ & $\begin{array}{l}\text { Ijolite } \\
\text { 007-D1 }\end{array}$ & $\begin{array}{c}\text { Cb- } \\
\text { bearing } \\
\text { NS } \\
\text { 008-D1 } \\
\end{array}$ & $\begin{array}{c}\text { Cb- } \\
\text { bearing } \\
\text { NS } \\
\text { 009-B2 } \\
\end{array}$ & $\begin{array}{c}\text { Cb- } \\
\text { bearing } \\
\text { NS } \\
\text { 008-C1 }\end{array}$ & $\begin{array}{c}\text { Cb- } \\
\text { bearing } \\
\text { NS } \\
\text { 012-G2 }\end{array}$ & $\begin{array}{c}\text { Cb- } \\
\text { bearing } \\
\text { NS } \\
\text { 007-E10 } \\
\end{array}$ & $\begin{array}{c}\text { Cb- } \\
\text { bearing } \\
\text { NS } \\
\text { 019-E1 } \\
\end{array}$ & $\begin{array}{c}\text { Cb- } \\
\text { bearing } \\
\text { NS } \\
\text { 008-E3 } \\
\end{array}$ & $\begin{array}{c}\text { Cb- } \\
\text { bearing } \\
\text { NS } \\
\text { 011-B3 }\end{array}$ \\
\hline $\mathrm{SiO}_{2}(w t . \%)$ & 42.38 & 41.51 & 441.51 & 40.00 & 433.81 & 499.64 & 46.45 & 488.91 & 50.53 & 47.12 & 46.77 & 52.84 & 53.93 \\
\hline $\mathbf{A l}_{2} \mathbf{O}_{3}$ & 14.89 & 13.89 & 16.03 & 14.28 & 17.37 & 21.15 & 17.96 & 17.59 & 19.86 & 16.69 & 17.48 & 19.10 & 21.91 \\
\hline $\mathrm{Fe}_{2} \mathrm{O}_{3(\mathrm{~T})}$ & 10.25 & 15.09 & 4.53 & 7.97 & 3.85 & 4.73 & 3.88 & 1.74 & 3.51 & 7.77 & 6.87 & 4.20 & 2.54 \\
\hline FeO & 6.88 & 11.26 & 3.34 & 6.00 & 2.75 & 3.59 & 2.83 & 1.29 & 2.59 & 5.90 & 5.11 & 3.13 & 1.89 \\
\hline $\mathrm{Fe}_{2} \mathrm{O}_{3}$ & 2.68 & 2.70 & 0.86 & 1.37 & 0.83 & 0.78 & 0.77 & 0.33 & 0.66 & 1.28 & 1.25 & 0.76 & 0.46 \\
\hline MgO & 3.35 & 4.56 & 1.48 & 2.29 & 0.98 & 0.89 & 1.32 & 0.28 & 0.89 & 1.79 & 2.37 & 0.80 & 0.38 \\
\hline MnO & 0.16 & 0.20 & 0.09 & 0.16 & 0.06 & 0.07 & 0.11 & 0.10 & 0.06 & 0.11 & 0.09 & 0.07 & 0.05 \\
\hline $\mathrm{CaO}$ & 9.07 & 6.59 & 12.72 & 12.62 & 11.12 & 4.60 & 8.75 & 10.44 & 5.68 & 7.37 & 7.50 & 5.21 & 4.01 \\
\hline $\mathrm{Na}_{2} \mathrm{O}$ & 5.63 & 3.22 & 3.90 & 5.84 & 6.98 & 9.04 & 8.96 & 7.76 & 8.82 & 6.42 & 7.58 & 8.00 & 9.46 \\
\hline $\mathrm{K}_{2} \mathrm{O}$ & 3.82 & 6.39 & 5.41 & 3.29 & 4.78 & 4.86 & 2.63 & 3.71 & 3.77 & 4.69 & 3.55 & 4.59 & 4.78 \\
\hline $\mathrm{TiO}_{2}$ & 2.53 & 2.55 & 0.71 & 1.22 & 0.68 & 0.63 & 0.62 & 0.18 & 0.51 & 1.13 & 1.10 & 0.61 & 0.31 \\
\hline $\mathrm{P}_{2} \mathrm{O}_{5}$ & 1.67 & 2.22 & 2.23 & 2.79 & 0.16 & 0.59 & 1.08 & 0.23 & 1.89 & 0.99 & 1.44 & 0.99 & 0.40 \\
\hline $\mathrm{Cr}_{2} \mathrm{O}_{3}$ & $<0.01$ & 0.01 & $<0.01$ & $<0.01$ & $<0.01$ & $<0.01$ & $<0.01$ & $<0.01$ & $<0.01$ & $<0.01$ & $<0.01$ & $<0.01$ & $<0.01$ \\
\hline LOI & 6.26 & 3.39 & 9.62 & 7.54 & 8.76 & 3.48 & 6.72 & 8.49 & 3.36 & 5.37 & 5.23 & 3.45 & 3.06 \\
\hline Total & 100.00 & 99.61 & 98.23 & 98.00 & 98.54 & 99.68 & 98.48 & 99.43 & 98.89 & 99.44 & 99.97 & 99.87 & 100.80 \\
\hline Sr (ppm) & 1658 & 1021 & 2785 & 1649 & 934 & 1248 & 1559 & 2332 & 954 & 1909 & 1588 & 1556 & 1521 \\
\hline $\mathbf{B a}$ & 630 & 1064 & 1464 & 285 & 921 & 1001 & 222 & 1037 & 456 & 944 & 436 & 1122 & 1339 \\
\hline $\mathrm{Nb}$ & 429 & 374 & 74 & 439 & 121 & 82 & 277 & 70 & 413 & 97 & 106 & 70 & 47 \\
\hline Ta & 35 & 24 & 10 & 99 & 14 & 8.8 & 99 & 24 & 87 & 8.0 & 13 & 6.7 & 4.2 \\
\hline $\mathbf{W}$ & $<0.5$ & $<0.5$ & $<0.5$ & $<0.5$ & $<0.5$ & $<0.5$ & 0.7 & $<0.5$ & $<0.5$ & $<0.5$ & $<0.5$ & $<0.5$ & 1.0 \\
\hline Tl & 0.5 & 0.8 & 0.2 & 0.5 & 0.2 & 0.4 & 0.3 & 0.3 & 0.5 & 0.3 & 0.3 & 0.3 & 0.3 \\
\hline $\mathbf{B i}$ & $<0.1$ & $<0.1$ & $<0.1$ & $<0.1$ & $<0.1$ & $<0.1$ & $<0.1$ & $<0.1$ & $<0.1$ & $<0.1$ & $<0.1$ & $<0.1$ & $<0.1$ \\
\hline Th & 3.4 & 2.6 & 6.5 & 18 & 0.8 & 0.6 & 6.4 & 8.9 & 18 & 1.5 & 6.6 & 0.9 & 0.8 \\
\hline $\mathbf{U}$ & 0.9 & 1.5 & 6.5 & 5.1 & 0.2 & 1.5 & 30 & 34 & 3.4 & 0.3 & 1.4 & 0.7 & 0.5 \\
\hline $\mathbf{V}$ & 182 & 197 & 73 & 111 & 36 & 43 & 66 & 16 & 54 & 107 & 104 & 42 & 23 \\
\hline $\mathbf{R b}$ & 148 & 337 & 102 & 209 & 72 & 122 & 93 & 65 & 127 & 86 & 77 & 109 & 87 \\
\hline $\mathbf{Y}$ & 25 & 23 & 39 & 35 & 7.2 & 12 & 23 & 32 & 19 & 20 & 25 & 15 & 10 \\
\hline $\mathbf{Z r}$ & 635 & 440 & 484 & 535 & 179 & 43 & 71 & 3720 & 520 & 321 & 546 & 863 & 349 \\
\hline La & 68 & 65 & 76 & 89 & 8.9 & 30 & 66 & 57 & 62 & 46 & 58 & 36 & 25 \\
\hline $\mathrm{Ce}$ & 148 & 147 & 171 & 203 & 25 & 67 & 141 & 118 & 140 & 99 & 130 & 82 & 53 \\
\hline Pr & 18 & 18 & 21 & 25 & 3.6 & 7.9 & 17 & 13 & 17 & 12 & 16 & 10 & 6.1 \\
\hline Nd & 69 & 71 & 84 & 94 & 15 & 31 & 62 & 50 & 64 & 46 & 63 & 39 & 23 \\
\hline Sm & 12 & 13 & 16 & 17 & 3.1 & 5.5 & 11 & 9.1 & 11 & 8.3 & 12 & 7.0 & 4.3 \\
\hline Eu & 3.5 & 3.7 & 4.8 & 5.0 & 1.0 & 1.6 & 3.1 & 2.7 & 3.2 & 2.5 & 3.4 & 2.1 & 1.3 \\
\hline Gd & 9.4 & 9.3 & 13 & 13 & 2.4 & 4.2 & 8.1 & 7.4 & 8.1 & 6.6 & 8.9 & 5.3 & 3.1 \\
\hline Tb & 1.1 & 1.2 & 1.6 & 1.6 & 0.3 & 0.5 & 1.0 & 1.1 & 1.0 & 0.9 & 1.2 & 0.7 & 0.4 \\
\hline Dy & 5.6 & 5.3 & 8.0 & 7.6 & 1.6 & 2.6 & 4.9 & 6.0 & 4.6 & 4.1 & 5.4 & 3.2 & 2.1 \\
\hline Ho & 1.0 & 0.9 & 1.4 & 1.3 & 0.3 & 0.5 & 0.9 & 1.2 & 0.7 & 0.7 & 1.0 & 0.6 & 0.4 \\
\hline $\mathbf{E r}$ & 2.3 & 2.1 & 3.4 & 3.1 & 0.7 & 1.2 & 2.1 & 3.4 & 1.7 & 1.9 & 2.4 & 1.4 & 1.0 \\
\hline $\mathbf{T m}$ & 0.3 & 0.2 & 0.4 & 0.4 & 0.1 & 0.2 & 0.3 & 0.5 & 0.2 & 0.2 & 0.3 & 0.2 & 0.1 \\
\hline $\mathbf{Y b}$ & 1.8 & 1.4 & 2.7 & 2.3 & 0.5 & 0.9 & 1.6 & 3.4 & 1.2 & 1.4 & 1.8 & 1.2 & 0.8 \\
\hline Lu & 0.3 & 0.2 & 0.4 & 0.3 & 0.1 & 0.1 & 0.2 & 0.6 & 0.2 & 0.2 & 0.3 & 0.2 & 0.1 \\
\hline IREE & 340 & 339 & 404 & 462 & 62 & 153 & 319 & 273 & 315 & 229 & 303 & 188 & 121 \\
\hline$[\mathbf{L a} / \mathbf{Y b}]_{\mathbf{N}}$ & 26 & 31 & 19 & 26 & 12 & 22 & 28 & 12 & 34 & 22 & 21 & 21 & 22 \\
\hline$[\mathbf{G d} / \mathbf{Y b}]_{\mathbf{N}}$ & 4.2 & 5.4 & 3.8 & 4.4 & 3.9 & 3.6 & 4.1 & 1.8 & 5.3 & 3.8 & 3.9 & 3.6 & 3.3 \\
\hline Cl & 0.2 & 0.1 & 0.0 & 0.0 & 0.0 & 0.1 & 0.1 & 0.1 & 0.1 & 0.1 & 0.1 & 0.0 & 0.0 \\
\hline $\mathbf{F}$ & 0.1 & 0.3 & 0.1 & 0.2 & 0.3 & 0.0 & 0.1 & $<0.01$ & 0.1 & 0.1 & 0.1 & 0.0 & $<0.01$ \\
\hline $\mathrm{Cu}$ & 30 & $<1$ & 2.0 & $<1$ & 11 & 6.0 & 1.0 & 7.0 & 11 & 1.0 & 1.0 & 2.0 & 3.0 \\
\hline $\mathbf{N i}$ & 9.0 & 22 & $<1$ & 3.0 & $<1$ & 2.0 & 6.0 & $<1$ & 2.0 & 12 & 12 & 2.0 & 2.0 \\
\hline Mo & $<1$ & $<1$ & $<1$ & $<1$ & $<1$ & 1 & $<1$ & $<1$ & 2.0 & $<1$ & $<1$ & 2 & $<1$ \\
\hline $\mathrm{Zn}$ & 151 & 274 & 73 & 128 & 53 & 69 & 65 & 27 & 65 & 114 & 105 & 59 & 38 \\
\hline $\mathbf{S}$ & 300 & 300 & 600 & 400 & 600 & 400 & 300 & 400 & 300 & 400 & 300 & 200 & 200 \\
\hline Au & $<2$ & $<2$ & $<2$ & $<2$ & $<2$ & $<2$ & $<2$ & $<2$ & $<2$ & $<2$ & $<2$ & $<2$ & $<2$ \\
\hline Ag & 3.2 & 2.1 & 2.3 & 2.6 & 0.9 & $<0.5$ & $<0.5$ & - & 2.6 & 1.6 & 2.6 & 4.5 & 1.9 \\
\hline As & $<0.5$ & $<0.5$ & $<0.5$ & $<0.5$ & $<0.5$ & $<0.5$ & $<0.5$ & $<0.5$ & $<0.5$ & $<0.5$ & $<0.5$ & $<0.5$ & $<0.5$ \\
\hline $\mathrm{Br}$ & 8.0 & $<0.5$ & $<0.5$ & $<0.5$ & $<0.5$ & $<0.5$ & 3.7 & 4.7 & 4.9 & 2.4 & 2.6 & 3.2 & $<0.5$ \\
\hline $\mathrm{Cr}$ & 9.0 & 55 & $<5$ & 6.0 & $<5$ & $<5$ & $<5$ & 7.0 & $<5$ & 8.0 & 18 & $<5$ & $<5$ \\
\hline Sc & 3.2 & 4.5 & 1.0 & 4.4 & 1.5 & 1.1 & 2.6 & 1.4 & 2.2 & 2.2 & 1.4 & 1.0 & 0.4 \\
\hline Sb & $<0.1$ & 0.3 & 0.2 & $<0.1$ & $<0.1$ & $<0.1$ & $<0.1$ & $<0.1$ & $<0.1$ & $<0.1$ & $<0.1$ & $<0.1$ & $<0.1$ \\
\hline Se & $<3$ & $<3$ & $<3$ & $<3$ & $<3$ & $<3$ & $<3$ & $<3$ & $<3$ & $<3$ & $<3$ & $<3$ & $<3$ \\
\hline Co & 18 & 23 & 6.0 & 11 & 3.0 & 5.0 & 6.0 & $<1$ & 3.0 & 10 & 10 & 5.0 & 2.0 \\
\hline $\mathbf{G a}$ & 36 & 45 & 33 & 49 & 21 & 27 & 45 & 25 & 43 & 38 & 32 & 28 & 24 \\
\hline Ge & 1.5 & 2.2 & 1.5 & 2.6 & 0.7 & 1.2 & 1.7 & 1.3 & 1.9 & 1.4 & 1.5 & 1.4 & 0.9 \\
\hline Sn & 3.0 & 3.0 & $<1$ & 1.0 & 2.0 & 1.0 & 1.0 & $<1$ & 1.0 & 2.0 & 1.0 & $<1$ & $<1$ \\
\hline Cs & 3.7 & 5.8 & 3.8 & 5.0 & 0.6 & 1.7 & 2.6 & 0.6 & 2.5 & 1.5 & 1.7 & 1.3 & 0.8 \\
\hline $\mathbf{P b}$ & 5.0 & $<3$ & 10 & 7.0 & $<3$ & $<3$ & 21 & 25 & 6.0 & $<3$ & $<3$ & $<3$ & $<3$ \\
\hline $\mathrm{Be}$ & 2.0 & 2.0 & 1.0 & 2.0 & 2.0 & 2.0 & 4.0 & 2.0 & 3.0 & 2.0 & 1.0 & 1.0 & 2.0 \\
\hline Hf & 11 & 9.3 & 9.4 & 9.0 & 3.6 & 0.6 & 1.8 & 47 & 8.8 & 6.3 & 7.6 & 8.9 & 4.3 \\
\hline Mg\# & 46 & 42 & 44 & 40 & 39 & 31 & 45 & 28 & 38 & 35 & 45 & 31 & 26 \\
\hline
\end{tabular}




\begin{tabular}{|c|c|c|c|c|c|c|c|c|c|c|c|c|}
\hline $\begin{array}{l}\text { Facies } \\
\text { Sample }\end{array}$ & $\begin{array}{c}\text { NS } \\
\text { 010-D2 }\end{array}$ & $\begin{array}{c}\text { NS } \\
011-G 1\end{array}$ & $\begin{array}{c}\text { NS } \\
019-G 2\end{array}$ & $\begin{array}{c}\text { NS } \\
008-B 1\end{array}$ & $\begin{array}{c}\text { NS } \\
\text { 011-B1 }\end{array}$ & $\begin{array}{c}\text { NS } \\
011-B 2\end{array}$ & $\begin{array}{c}\text { NS } \\
007-B 1\end{array}$ & $\begin{array}{c}\mathrm{NS} \\
006-\mathrm{C} 3\end{array}$ & $\begin{array}{c}\mathrm{NS} \\
\text { 004-C1 }\end{array}$ & $\begin{array}{c}\text { NS } \\
012-G 2\end{array}$ & $\begin{array}{c}\text { NS } \\
012-G 3\end{array}$ & $\begin{array}{c}\mathrm{NS} \\
004-\mathrm{C} 2\end{array}$ \\
\hline $\mathrm{SiO}_{2}(w t . \%)$ & "49.32 & 254.10 & 54.15 & 53.94 & "53.87 & "58.98 & 254.51 & $\begin{array}{c}59.72 \\
\end{array}$ & "56.12 & $\bar{~} 59.46$ & "56.76 & $\bar{~} 56.10$ \\
\hline $\mathbf{A l}_{2} \mathbf{O}_{3}$ & 21.59 & 20.14 & 19.86 & 21.59 & 21.10 & 22.36 & 23.32 & 23.01 & 23.44 & 23.13 & 21.59 & 25.27 \\
\hline $\mathrm{Fe}_{2} \mathrm{O}_{3(\mathrm{~T})}$ & 5.53 & 3.02 & 3.61 & 2.89 & 2.41 & 1.08 & 1.80 & 1.06 & 1.22 & 2.24 & 0.73 & 1.36 \\
\hline $\mathrm{FeO}$ & 3.98 & 2.30 & 2.60 & 2.18 & 1.79 & 0.75 & 1.26 & 0.73 & 0.89 & 1.68 & 0.50 & 1.00 \\
\hline $\mathrm{Fe}_{2} \mathrm{O}_{3}$ & 1.15 & 0.49 & 0.75 & 0.49 & 0.44 & 0.25 & 0.41 & 0.25 & 0.24 & 0.39 & 0.18 & 0.26 \\
\hline MgO & 0.95 & 0.43 & 0.90 & 0.42 & 0.35 & 0.25 & 0.47 & 0.22 & 0.13 & 0.02 & 0.09 & 0.05 \\
\hline MnO & 0.08 & 0.06 & 0.03 & 0.05 & 0.05 & 0.02 & 0.04 & 0.02 & 0.02 & 0.03 & 0.03 & 0.02 \\
\hline $\mathrm{CaO}$ & 3.54 & 3.48 & 2.61 & 3.24 & 3.20 & 0.99 & 2.45 & 0.79 & 0.49 & 0.30 & 1.66 & 0.30 \\
\hline $\mathrm{Na}_{2} \mathrm{O}$ & 8.66 & 8.59 & 7.16 & 9.08 & 9.04 & 11.34 & 11.12 & 11.51 & 10.06 & 12.63 & 11.53 & 12.38 \\
\hline $\mathbf{K}_{2} \mathbf{O}$ & 5.41 & 4.54 & 5.59 & 4.69 & 4.61 & 1.89 & 2.92 & 2.03 & 5.25 & 1.81 & 1.68 & 3.94 \\
\hline $\mathrm{TiO}_{2}$ & 1.00 & 0.34 & 0.60 & 0.34 & 0.29 & 0.10 & 0.26 & 0.10 & 0.09 & 0.24 & 0.03 & 0.11 \\
\hline $\mathrm{P}_{2} \mathrm{O}_{5}$ & 0.36 & 0.32 & 0.21 & 0.53 & 0.48 & 0.07 & 0.21 & 0.05 & 0.12 & 0.08 & 0.25 & 0.06 \\
\hline $\mathrm{Cr}_{2} \mathrm{O}_{3}$ & $<0.01$ & $<0.01$ & $<0.01$ & $<0.01$ & $<0.01$ & $<0.01$ & $<0.01$ & $<0.01$ & $<0.01$ & $<0.01$ & $<0.01$ & $<0.01$ \\
\hline LOI & 2.65 & 2.60 & 4.42 & 2.12 & 2.23 & 1.79 & 2.99 & 1.69 & 1.46 & 0.55 & 3.15 & 0.56 \\
\hline Total & 99.11 & 97.59 & 99.14 & 98.89 & 97.63 & 98.88 & 100.10 & 100.20 & 98.41 & 100.50 & 97.50 & 100.20 \\
\hline Sr (ppm) & 1154 & 1282 & 1083 & 1497 & 1347 & 201 & 586 & 194 & 161 & 66 & 383 & 96 \\
\hline $\mathrm{Ba}$ & 1611 & 991 & 1474 & 1322 & 1272 & 106 & 238 & 52 & 91 & 18 & 147 & 35 \\
\hline Nb & 157 & 79 & 70 & 50 & 40 & 905 & 154 & 1850 & 2290 & 1200 & 945 & 1170 \\
\hline Ta & 11 & 21 & 7.7 & 4.8 & 5.3 & 254 & 62 & 249 & 326 & 139 & 178 & 141 \\
\hline W & $<0.5$ & $<0.5$ & 1.4 & $<0.5$ & $<0.5$ & 1.0 & 0.8 & $<0.5$ & 0.6 & $<0.5$ & 1.1 & $<0.5$ \\
\hline Tl & 0.5 & 0.3 & 0.2 & 0.3 & 0.2 & 0.3 & 0.3 & 0.2 & 0.6 & 0.3 & 0.2 & 0.5 \\
\hline $\mathbf{B i}$ & $<0.1$ & $<0.1$ & $<0.1$ & $<0.1$ & $<0.1$ & $<0.1$ & $<0.1$ & 0.1 & 0.2 & 0.1 & $<0.1$ & $<0.1$ \\
\hline Th & 0.5 & 1.9 & 3.0 & 0.6 & 1.3 & 52 & 8.1 & 49 & 93 & 39 & 30 & 41 \\
\hline $\mathbf{U}$ & 0.5 & 22 & 1.5 & 0.5 & 2.8 & 14 & 67 & 0.1 & 1.5 & 0.2 & 2.0 & 1.5 \\
\hline V & 55 & 24 & 54 & 19 & 22 & 12 & 27 & 8.0 & 10 & 17 & 8.0 & 11 \\
\hline $\mathbf{R b}$ & 146 & 100 & 66 & 97 & 86 & 42 & 54 & 55 & 110 & 36 & 35 & 86 \\
\hline Y & 10 & 12 & 7.4 & 8.9 & 10 & 10 & 8.1 & 4.2 & 2.6 & 3.1 & 7.7 & 1.5 \\
\hline $\mathrm{Zr}$ & 69 & 1000 & 811 & 190 & 195 & 3360 & 1340 & 636 & 153 & 1800 & 2060 & 153 \\
\hline La & 27 & 22 & 19 & 23 & 25 & 22 & 23 & 13 & 16 & 5.6 & 26 & 8.1 \\
\hline $\mathrm{Ce}$ & 58 & 47 & 38 & 53 & 54 & 39 & 44 & 27 & 39 & 12 & 52 & 18 \\
\hline Pr & 7.1 & 5.7 & 4 & 6.3 & 6.5 & 3.9 & 5.0 & 2.7 & 3.9 & 1.3 & 5.7 & 1.8 \\
\hline Nd & 27 & 21 & 17 & 23 & 24 & 13 & 18 & 9 & 13 & 4.5 & 20 & 6.0 \\
\hline Sm & 4.8 & 4.1 & 3 & 4.2 & 4.5 & 2.1 & 3.1 & 1.3 & 2.1 & 0.7 & 3.5 & 1.0 \\
\hline Eu & 1.4 & 1.2 & 0.9 & 1.3 & 1.3 & 0.6 & 0.9 & 0.4 & 0.6 & 0.2 & 1.0 & 0.3 \\
\hline Gd & 3.4 & 3.2 & 2.2 & 3.1 & 3.3 & 1.6 & 2.5 & 0.8 & 1.3 & 0.5 & 2.3 & 0.6 \\
\hline Tb & 0.5 & 0.4 & 0.3 & 0.4 & 0.4 & 0.3 & 0.3 & 0.2 & 0.1 & 0.1 & 0.3 & 0.1 \\
\hline Dy & 2.2 & 2.3 & 1.6 & 2.0 & 2.1 & 1.6 & 1.7 & 0.8 & 0.6 & 0.6 & 1.5 & 0.4 \\
\hline Ho & 0.4 & 0.4 & 0.3 & 0.3 & 0.4 & 0.4 & 0.3 & 0.2 & 0.1 & 0.1 & 0.3 & 0.1 \\
\hline Er & 0.9 & 1.2 & 0.8 & 0.9 & 1.0 & 1.3 & 0.8 & 0.5 & 0.3 & 0.4 & 0.8 & 0.2 \\
\hline Tm & 0.1 & 0.2 & 0.1 & 0.1 & 0.1 & 0.2 & 0.1 & 0.1 & 0.0 & 0.1 & 0.1 & 0.0 \\
\hline $\mathbf{Y b}$ & 0.7 & 1.3 & 0.8 & 0.7 & 0.8 & 1.6 & 0.8 & 0.5 & 0.2 & 0.5 & 0.8 & 0.1 \\
\hline Lu & 0.1 & 0.2 & 0.1 & 0.1 & 0.1 & 0.3 & 0.1 & 0.1 & 0.0 & 0.1 & 0.1 & 0.0 \\
\hline ¿REE & 133 & 110 & 87 & 119 & 123 & 87 & 101 & 55 & 77 & 27 & 115 & 36 \\
\hline$[\mathbf{L a} / \mathbf{Y b}]_{\mathbf{N}}$ & 27 & 11 & 17 & 23 & 21 & 9.2 & 18 & 19 & 65 & 7.6 & 24 & 46 \\
\hline$[\mathbf{G d} / \mathbf{Y b}]_{\mathbf{N}}$ & 4.1 & 2.0 & 2.4 & 3.5 & 3.3 & 0.8 & 2.4 & 1.5 & 6.3 & 0.8 & 2.5 & 4.0 \\
\hline Cl & 0.0 & 0.0 & 0.1 & 0.0 & 0.1 & 0.1 & 0.0 & 0.1 & 0.1 & 0.0 & 0.2 & 0.0 \\
\hline $\mathbf{F}$ & 0.0 & $<0.01$ & $<0.01$ & 0.0 & $<0.01$ & $<0.01$ & $<0.01$ & $<0.01$ & $<0.01$ & $<0.01$ & $<0.01$ & $<0.01$ \\
\hline $\mathrm{Cu}$ & 12 & $<1$ & 8.0 & 1.0 & 7.0 & 23 & 23 & 31 & 5.0 & 7.0 & 4.0 & 15 \\
\hline $\mathbf{N i}$ & 4.0 & 5.0 & 4.0 & 2.0 & $<1$ & 2.0 & 2.0 & 2.0 & 2.0 & 1.0 & $<1$ & 1.0 \\
\hline Mo & $<1$ & $<1$ & 2.0 & $<1$ & $<1$ & 2.0 & 1.0 & 1.0 & 1.0 & $<1$ & 2.0 & $<1$ \\
\hline Zn & 117 & 58 & 60 & 51 & 38 & 32 & 33 & 31 & 28 & 48 & 22 & 19 \\
\hline $\mathbf{S}$ & 600 & 200 & 700 & 200 & 200 & 100 & 300 & 400 & 900 & $<100$ & 100 & $<100$ \\
\hline Au & $<2$ & $<2$ & $<2$ & $<2$ & $<2$ & $<2$ & 4.0 & $<2$ & $<2$ & $<2$ & $<2$ & $<2$ \\
\hline Ag & $<0.5$ & - & 4.1 & 0.9 & 0.8 & - & - & 3.2 & 0.7 & - & - & 0.7 \\
\hline As & $<0.5$ & $<0.5$ & 0.9 & $<0.5$ & $<0.5$ & $<0.5$ & $<0.5$ & $<0.5$ & $<0.5$ & $<0.5$ & $<0.5$ & $<0.5$ \\
\hline $\mathrm{Br}$ & $<0.5$ & $<0.5$ & 6.2 & 3.4 & 2.3 & 2.9 & 8.4 & 10 & 10 & $<0.5$ & 16 & $<0.5$ \\
\hline $\mathrm{Cr}$ & 6.0 & $<5$ & $<5$ & $<5$ & $<5$ & $<5$ & $<5$ & $<5$ & $<5$ & $<5$ & $<5$ & $<5$ \\
\hline Sc & 1.3 & 0.8 & 0.5 & 0.4 & 0.4 & 2.3 & 2.0 & 1.6 & 1.4 & 1.4 & 2.0 & 1.0 \\
\hline Sb & 0.3 & 0.4 & 0.3 & $<0.1$ & $<0.1$ & $<0.1$ & $<0.1$ & $<0.1$ & $<0.1$ & $<0.1$ & $<0.1$ & 0.4 \\
\hline $\mathrm{Se}$ & $<3$ & $<3$ & $<3$ & $<3$ & $<3$ & $<3$ & $<3$ & $<3$ & $<3$ & $<3$ & $<3$ & $<3$ \\
\hline Co & 7.0 & 3.0 & 6.0 & 3.0 & 10 & $<1$ & 2.0 & 1.0 & $<1$ & $<1$ & $<1$ & $<1$ \\
\hline Ga & 25 & 30 & 36 & 27 & 25 & 32 & 39 & 39 & 34 & 41 & 40 & 36 \\
\hline Ge & 1.0 & 1.3 & 1.2 & 1.1 & 0.9 & 1.1 & 1.4 & 1.3 & 1.1 & 1.7 & 1.3 & 1.2 \\
\hline Sn & 1.0 & $<1$ & $<1$ & $<1$ & $<1$ & $<1$ & $<1$ & $<1$ & 1.0 & 1.0 & $<1$ & $<1$ \\
\hline Cs & 1.6 & 0.9 & 1.4 & 0.9 & 0.7 & 0.9 & 1.0 & 0.9 & 0.7 & 0.2 & 0.6 & 0.6 \\
\hline $\mathbf{P b}$ & $<3$ & 12 & $<3$ & $<3$ & $<3$ & 12 & 37 & $<3$ & 4.0 & $<3$ & 7.0 & $<3$ \\
\hline $\mathrm{Be}$ & 2.0 & 1.0 & 2.0 & 2.0 & 1.0 & 4.0 & 3.0 & 5.0 & 5.0 & 5.0 & 4.0 & 5.0 \\
\hline Hf & 1.4 & 15 & 11 & 2.5 & 3.1 & 33 & 22 & 8.5 & 2.7 & 22 & 30 & 3.2 \\
\hline Mg\# & 30 & 25 & 38 & 26 & 26 & 37 & 40 & 35 & 21 & 2 & 24 & 8 \\
\hline
\end{tabular}

${ }^{1}$ Sample names follow the format $12-P A-X X X-X X$. 
Table 3. Representative magmatic pyrochlore compositions and structural formula from different syenite facies of the Crevier alkaline intrusion from the central Grenville Province obtained using EPMA. Abbreviations: apfu $=$ atoms per formula unit; Neph. Sye. = nepheline syenite. General formula: $\mathrm{A}_{2-\mathrm{m}} \mathrm{B}_{2} \mathrm{X}_{6-\mathrm{w}} \mathrm{Y}_{1-\mathrm{n}}$ (Atencio et al., 2010) with $\mathrm{m}, \mathrm{w}$ and $\mathrm{n}$ corresponding to the vacancieseccupancy of the different sites.

\begin{tabular}{|c|c|c|c|c|c|c|c|c|c|c|c|}
\hline Mineral & Pyrochlore & & & & & & & & & & \\
\hline $\begin{array}{l}\text { Sample }^{1} \\
\text { Facies } \\
\text { Analysis no. }{ }^{2} \\
\end{array}$ & $\begin{array}{c}\text { 002-G1 } \\
\text { Neph. Sye. } \\
5-3 \\
\end{array}$ & $\begin{array}{c}\text { 002-G1 } \\
\text { Neph. } \\
\text { Sye. } \\
\text { 6-3 } \\
\end{array}$ & $\begin{array}{c}\text { 006-C2 } \\
\text { Neph. } \\
\text { Sye. } \\
2-16 \\
\end{array}$ & $\begin{array}{c}\text { 006-C3 } \\
\text { Neph. } \\
\text { Sye. } \\
\text { 10-2 } \\
\end{array}$ & $\begin{array}{c}\text { 006-C3 } \\
\text { Neph. } \\
\text { Sye. } \\
7-2 \\
\end{array}$ & $\begin{array}{c}\text { 006-C3 } \\
\text { Neph. } \\
\text { Sye. } \\
\text { 8-3 } \\
\end{array}$ & $\begin{array}{c}\text { 012-G4 } \\
\text { Neph. } \\
\text { Sye. } \\
\text { 6-7 } \\
\end{array}$ & $\begin{array}{c}010-G 1 \\
\text { Ocelli } \\
\text { facies } \\
6-8 \\
\end{array}$ & $\begin{array}{c}\text { 010-G1 } \\
\text { Ocelli } \\
\text { facies } \\
6-9 \\
\end{array}$ & $\begin{array}{c}010-G 2 \\
\text { Ocelli } \\
\text { facies } \\
3-6 \\
\end{array}$ & $\begin{array}{c}\text { 010-G2 } \\
\text { Ocelli } \\
\text { facies } \\
4-11 \\
\end{array}$ \\
\hline \multicolumn{12}{|l|}{ A-site } \\
\hline $\mathrm{UO}_{2}(w t . \%)$ & 0.00 & 0.00 & 0.00 & 0.00 & 0.00 & 0.00 & 0.00 & 0.41 & 1.94 & 0.00 & 0.16 \\
\hline $\mathrm{ThO}_{2}$ & 2.75 & 1.38 & 1.20 & 1.04 & 0.82 & 1.07 & 1.16 & 1.00 & 0.65 & 0.97 & 0.92 \\
\hline $\mathrm{SnO}_{2}$ & 0.04 & 0.00 & 0.00 & 0.04 & 0.00 & 0.00 & 0.00 & 0.00 & 0.04 & 0.00 & 0.02 \\
\hline $\mathrm{Sc}_{2} \mathrm{O}_{3}$ & 0.00 & 0.00 & 0.00 & 0.00 & 0.00 & 0.00 & 0.00 & 0.00 & 0.00 & 0.00 & 0.00 \\
\hline $\mathbf{Y}_{2} \mathbf{O}_{3}$ & 0.00 & 0.00 & 0.00 & 0.00 & 0.00 & 0.00 & 0.10 & 0.00 & 0.00 & 0.02 & 0.00 \\
\hline $\mathrm{La}_{2} \mathrm{O}_{3}$ & 0.07 & 0.14 & 0.10 & 0.13 & 0.09 & 0.03 & 0.07 & 0.14 & 0.08 & 0.04 & 0.06 \\
\hline $\mathrm{Ce}_{2} \mathrm{O}_{3}$ & 0.34 & 0.40 & 0.26 & 0.51 & 0.30 & 0.27 & 0.31 & 0.46 & 0.27 & 0.25 & 0.41 \\
\hline $\mathrm{Pr}_{2} \mathrm{O}_{3}$ & 0.00 & 0.00 & 0.00 & 0.00 & 0.00 & 0.00 & 0.00 & 0.00 & 0.00 & 0.00 & 0.00 \\
\hline MnO & 0.00 & 0.08 & 0.00 & 0.03 & 0.05 & 0.00 & 0.00 & 0.00 & 0.00 & 0.00 & 0.05 \\
\hline $\mathrm{CaO}$ & 13.18 & 13.05 & 13.11 & 12.08 & 14.02 & 13.49 & 14.02 & 14.86 & 13.73 & 15.35 & 12.18 \\
\hline SrO & 1.17 & 1.73 & 1.21 & 0.97 & 1.12 & 0.99 & 0.10 & 1.78 & 0.87 & 0.69 & 1.34 \\
\hline $\mathrm{BaO}$ & 0.00 & 0.25 & 0.06 & 0.01 & 0.07 & 0.02 & 0.00 & 0.00 & 0.00 & 0.00 & 0.23 \\
\hline PbO & 0.00 & 0.00 & 0.00 & 0.00 & 0.00 & 0.00 & 0.00 & 0.00 & 0.00 & 0.00 & 0.00 \\
\hline $\mathrm{Na}_{2} \mathrm{O}$ & 7.51 & 6.39 & 7.80 & 7.87 & 6.32 & 7.83 & 8.06 & 6.76 & 6.64 & 6.83 & 6.50 \\
\hline $\mathbf{K}_{2} \mathbf{O}$ & 0.02 & 0.17 & 0.03 & 0.05 & 0.21 & 0.01 & 0.06 & 0.01 & 0.01 & 0.00 & 0.08 \\
\hline \multicolumn{12}{|l|}{$B$-site } \\
\hline $\mathrm{WO}_{3}$ & 0.00 & 0.00 & 0.00 & 0.00 & 0.00 & 0.00 & 0.00 & 0.00 & 0.00 & 0.00 & 0.00 \\
\hline $\mathrm{Nb}_{2} \mathrm{O}_{5}$ & 60.64 & 55.92 & 64.13 & 59.07 & 56.02 & 65.63 & 64.14 & 56.60 & 53.93 & 64.48 & 53.22 \\
\hline $\mathrm{Ta}_{2} \mathrm{O}_{5}$ & 9.04 & 9.49 & 6.63 & 6.88 & 7.15 & 6.07 & 3.76 & 9.57 & 15.64 & 4.77 & 16.06 \\
\hline $\mathrm{SiO}_{2}$ & 0.00 & 1.79 & 0.15 & 1.12 & 2.22 & 0.01 & 0.02 & 0.05 & 0.00 & 0.00 & 0.72 \\
\hline $\mathrm{TiO}_{2}$ & 2.01 & 1.78 & 0.83 & 4.00 & 2.25 & 1.03 & 4.00 & 1.86 & 2.14 & 2.66 & 1.37 \\
\hline $\mathrm{ZrO}_{2}$ & 0.00 & 0.09 & 0.10 & 0.00 & 0.00 & 0.00 & 0.03 & 0.00 & 0.06 & 0.00 & 0.53 \\
\hline $\mathbf{A l}_{2} \mathbf{O}_{3}$ & 0.04 & 0.18 & 0.06 & 0.11 & 0.19 & 0.16 & 0.02 & 0.47 & 0.04 & 0.00 & 0.08 \\
\hline $\mathrm{Fe}_{2} \mathrm{O}_{3}$ & 0.04 & 2.56 & 0.22 & 1.07 & 2.32 & 0.04 & 0.11 & 0.21 & 0.08 & 0.05 & 1.13 \\
\hline \multicolumn{12}{|l|}{$X / Y$-site } \\
\hline $\mathbf{F}$ & 4.83 & 3.62 & 4.65 & 4.16 & 4.03 & 4.97 & 4.16 & 4.80 & 3.92 & 4.76 & 3.97 \\
\hline $\mathrm{H}_{2} \mathrm{O}$ & 0.07 & 0.77 & 0.18 & 0.55 & 0.57 & 0.07 & 0.51 & 0.00 & 0.42 & 0.18 & 0.47 \\
\hline Total & 101.75 & 99.79 & 100.72 & 99.69 & 97.75 & 101.69 & 100.63 & 98.98 & 100.46 & 101.05 & 99.50 \\
\hline$.-O=F$ & 2.03 & 1.52 & 1.96 & 1.75 & 1.70 & 2.09 & 1.75 & 2.02 & 1.65 & 2.00 & 1.67 \\
\hline Total & 99.71 & 98.27 & 98.77 & 97.94 & 96.06 & 99.59 & 98.88 & 96.96 & 98.81 & 99.04 & 97.83 \\
\hline \multicolumn{12}{|l|}{$\overline{A \text {-site }}$} \\
\hline $\mathrm{U}^{4+}(a p f u)$ & 0.000 & 0.000 & 0.000 & 0.000 & 0.000 & 0.000 & 0.000 & 0.006 & 0.028 & 0.000 & 0.002 \\
\hline $\mathbf{T h}^{4+}$ & 0.040 & 0.019 & 0.017 & 0.014 & 0.011 & 0.015 & 0.016 & 0.015 & 0.010 & 0.014 & 0.013 \\
\hline $\mathrm{Sn}^{4+}$ & 0.001 & 0.000 & 0.000 & 0.001 & 0.000 & 0.000 & 0.000 & 0.000 & 0.001 & 0.000 & 0.001 \\
\hline $\mathrm{Sc}^{3+}$ & 0.000 & 0.000 & 0.000 & 0.000 & 0.000 & 0.000 & 0.000 & 0.000 & 0.000 & 0.000 & 0.000 \\
\hline $\mathbf{Y}^{3+}$ & 0.000 & 0.000 & 0.000 & 0.000 & 0.000 & 0.000 & 0.003 & 0.000 & 0.000 & 0.001 & 0.000 \\
\hline $\mathbf{L a}^{3+}$ & 0.002 & 0.003 & 0.002 & 0.003 & 0.002 & 0.001 & 0.002 & 0.003 & 0.002 & 0.001 & 0.001 \\
\hline $\mathrm{Ce}^{3+}$ & 0.008 & 0.009 & 0.006 & 0.011 & 0.007 & 0.006 & 0.007 & 0.011 & 0.007 & 0.006 & 0.010 \\
\hline $\mathbf{P r}^{3+}$ & 0.000 & 0.000 & 0.000 & 0.000 & 0.000 & 0.000 & 0.000 & 0.000 & 0.000 & 0.000 & 0.000 \\
\hline $\mathrm{Mn}^{2+}$ & 0.000 & 0.004 & 0.000 & 0.002 & 0.003 & 0.000 & 0.000 & 0.000 & 0.000 & 0.000 & 0.003 \\
\hline $\mathrm{Ca}^{+}$ & 0.898 & 0.843 & 0.882 & 0.770 & 0.906 & 0.894 & 0.906 & 1.049 & 0.968 & 1.013 & 0.832 \\
\hline $\mathrm{Sr}^{2+}$ & 0.043 & 0.060 & 0.044 & 0.033 & 0.039 & 0.036 & 0.003 & 0.068 & 0.033 & 0.025 & 0.050 \\
\hline $\mathrm{Ba}^{2+}$ & 0.000 & 0.006 & 0.001 & 0.000 & 0.002 & 0.000 & 0.000 & 0.000 & 0.000 & 0.000 & 0.006 \\
\hline $\mathbf{P b}^{2+}$ & 0.000 & 0.000 & 0.000 & 0.000 & 0.000 & 0.000 & 0.000 & 0.000 & 0.000 & 0.000 & 0.000 \\
\hline $\mathbf{N a}^{+}$ & 0.926 & 0.747 & 0.950 & 0.907 & 0.739 & 0.939 & 0.942 & 0.864 & 0.848 & 0.815 & 0.803 \\
\hline $\mathbf{K}^{+}$ & 0.002 & 0.013 & 0.002 & 0.004 & 0.016 & 0.001 & 0.005 & 0.001 & 0.001 & 0.000 & 0.007 \\
\hline \multicolumn{12}{|l|}{$B$-site } \\
\hline $\mathbf{W}^{6+}$ & 0.000 & 0.000 & 0.000 & 0.000 & 0.000 & 0.000 & 0.000 & 0.000 & 0.000 & 0.000 & 0.000 \\
\hline $\mathbf{N b}^{5^{+}}$ & 1.743 & 1.524 & 1.820 & 1.588 & 1.528 & 1.836 & 1.748 & 1.686 & 1.605 & 1.795 & 1.533 \\
\hline $\mathbf{T a}^{5+}$ & 0.156 & 0.156 & 0.113 & 0.111 & 0.117 & 0.102 & 0.062 & 0.171 & 0.280 & 0.080 & 0.278 \\
\hline $\mathrm{Si}^{4+}$ & 0.000 & 0.108 & 0.009 & 0.067 & 0.134 & 0.001 & 0.001 & 0.003 & 0.000 & 0.000 & 0.046 \\
\hline $\mathbf{T i}^{4+}$ & 0.096 & 0.081 & 0.039 & 0.179 & 0.102 & 0.048 & 0.181 & 0.092 & 0.106 & 0.123 & 0.066 \\
\hline $\mathbf{Z r}^{4+}$ & 0.000 & 0.003 & 0.003 & 0.000 & 0.000 & 0.000 & 0.001 & 0.000 & 0.002 & 0.000 & 0.016 \\
\hline $\mathbf{A l}^{3+}$ & 0.003 & 0.013 & 0.004 & 0.008 & 0.014 & 0.012 & 0.001 & 0.037 & 0.003 & 0.000 & 0.006 \\
\hline $\mathrm{Fe}^{3+}$ & 0.002 & 0.116 & 0.010 & 0.048 & 0.105 & 0.002 & 0.005 & 0.010 & 0.004 & 0.002 & 0.054 \\
\hline \multicolumn{12}{|l|}{$X / Y$-site } \\
\hline $\mathbf{F}^{-}$ & 0.971 & 0.690 & 0.923 & 0.782 & 0.769 & 0.973 & 0.793 & 1.000 & 0.816 & 0.927 & 0.800 \\
\hline $\mathrm{OH}^{-}$ & 0.029 & 0.310 & 0.077 & 0.218 & 0.231 & 0.027 & 0.207 & 0.000 & 0.184 & 0.073 & 0.200 \\
\hline Total & 4.918 & 4.704 & 4.905 & 4.745 & 4.725 & 4.892 & 4.884 & 5.017 & 4.898 & 4.873 & 4.726 \\
\hline $\mathbf{A}$ & 1.92 & 1.70 & 1.90 & 1.74 & 1.72 & 1.89 & 1.88 & 2.02 & 1.90 & 1.87 & 1.73 \\
\hline B & 2.00 & 2.00 & 2.00 & 2.00 & 2.00 & 2.00 & 2.00 & 2.00 & 2.00 & 2.00 & 2.00 \\
\hline OH & 0.03 & 0.31 & 0.08 & 0.22 & 0.23 & 0.03 & 0.21 & 0.00 & 0.18 & 0.07 & 0.20 \\
\hline $\mathbf{F}$ & 0.97 & 0.69 & 0.92 & 0.78 & 0.77 & 0.97 & 0.79 & 1.00 & 0.82 & 0.93 & 0.80 \\
\hline
\end{tabular}


A-site

$0.08 \quad 0.30$

0.10

0.26

0.28

0.11

0.12

$-0.02$

0.10

0.13

0.27

$\%$ vacancy

$4.1 \quad 14.8$

13.8

5.4

5.8

$-0.9$

5.1

6.3

13.7

${ }^{1}$ Sample names follow the format $12-P A-X X X-X X$.

${ }^{2}$ All analyses are reported in Table S1.

${ }^{3} \mathrm{OH}$ has been calculated to fill the Y site. 
Table 4: Apatite compositions from carbonatite facies (sample 12-PA-007-A6) of the Crevier alkaline intrusion from the central Grenville Province obtained using EPMA. They are reported with confidence interval of $95 \%$ in brackets $(n=$ number of analyses).

\begin{tabular}{|c|c|}
\hline Mineral & Apatite \\
\hline $\mathrm{n}$ & 195 \\
\hline \multicolumn{2}{|l|}{ Ca-site } \\
\hline $\mathrm{CaO}(w t . \%)$ & $\begin{array}{r}54.90 \\
(0.13)\end{array}$ \\
\hline $\mathrm{Na}_{2} \mathrm{O}$ & $\begin{array}{r}0.36 \\
(0.02)\end{array}$ \\
\hline MgO & $\begin{array}{r}0.04 \\
(0.06)\end{array}$ \\
\hline $\mathrm{FeO}$ & $\begin{array}{r}0.10 \\
(0.04)\end{array}$ \\
\hline SrO & $\begin{array}{r}0.92 \\
(0.02)\end{array}$ \\
\hline MnO & $\begin{array}{r}0.03 \\
(0.00)\end{array}$ \\
\hline $\mathbf{L a}_{2} \mathbf{O}_{3}$ & $\begin{array}{r}0.15 \\
(0.01)\end{array}$ \\
\hline $\mathrm{Ce}_{2} \mathrm{O}_{3}$ & $\begin{array}{r}0.34 \\
(0.02)\end{array}$ \\
\hline $\mathbf{N d}_{2} \mathrm{O}_{3}$ & $\begin{array}{r}0.19 \\
(0.01)\end{array}$ \\
\hline \multicolumn{2}{|l|}{$P$-site } \\
\hline $\mathbf{P}_{2} \mathbf{O}_{5}$ & $\begin{array}{l}43.03 \\
(0.15)\end{array}$ \\
\hline $\mathrm{SiO}_{2}$ & $\begin{array}{r}0.02 \\
(0.02)\end{array}$ \\
\hline $\mathrm{SO}_{3}$ & $\begin{array}{r}0.01 \\
(0.00)\end{array}$ \\
\hline \multicolumn{2}{|l|}{ F-site } \\
\hline $\mathbf{F}$ & $\begin{array}{r}3.16 \\
(0.04)\end{array}$ \\
\hline Cl & $\begin{array}{r}0.01 \\
(0.00)\end{array}$ \\
\hline Total & $\begin{array}{r}103.41 \\
(0.15) \\
\end{array}$ \\
\hline \multicolumn{2}{|c|}{$\begin{array}{l}\text { Atoms per formula unit } \\
\text { calculated on the basis of } 12.50 \\
\text { Ca-site }\end{array}$} \\
\hline $\mathrm{Ca}$ & $\begin{array}{r}4.855 \\
(0.014)\end{array}$ \\
\hline $\mathbf{N a}$ & $\begin{array}{r}0.057 \\
(0.003)\end{array}$ \\
\hline Mg & $\begin{array}{r}0.005 \\
(0.007)\end{array}$ \\
\hline $\mathrm{Fe}$ & $\begin{array}{r}0.007 \\
(0.003)\end{array}$ \\
\hline $\mathbf{S r}$ & $\begin{array}{r}0.044 \\
(0.001)\end{array}$ \\
\hline Mn & $\begin{array}{r}0.002 \\
(0.000)\end{array}$ \\
\hline $\mathbf{L a}$ & $\begin{array}{r}0.007 \\
(0.001)\end{array}$ \\
\hline $\mathrm{Ce}$ & $\begin{array}{r}0.010 \\
(0.001)\end{array}$ \\
\hline Nd & $\begin{array}{r}0.006 \\
(0.000)\end{array}$ \\
\hline
\end{tabular}




\begin{tabular}{lr}
$\boldsymbol{P}$-site & \\
$\mathbf{P}$ & 3.005 \\
& $(0.006)$ \\
$\mathbf{S i}$ & 0.002 \\
& $(0.002)$ \\
$\mathbf{S}$ & 0.001 \\
& $(0.000)$ \\
$\boldsymbol{F}$-site & \\
$\mathbf{F}$ & 0.825 \\
& $(0.010)$ \\
$\mathbf{C l}$ & 0.001 \\
& $(0.000)$ \\
Ca-site & 4.993 \\
P-site & 3.008 \\
F-site & 0.827 \\
\hline
\end{tabular}


Table 5: Summary of the results obtained on zircon grains from the carbonate-bearing nepheline syenite (sample 12-PA-011-B11) of the Crevier alkaline intrusion from the central Grenville Province. The zircon grains are grouped according to the classification of Figs. 10 and 11 . Abbreviation: Temp. $=$ temperature.

\begin{tabular}{|c|c|c|c|c|c|c|c|c|c|c|c|c|c|c|c|c|c|c|c|}
\hline Zone $^{\mathrm{a}}$ & $\begin{array}{l}\text { LREE- } \\
\text { Ca-Fe } \\
\text { content }\end{array}$ & $\begin{array}{c}\mathrm{Ca} \\
(\mathbf{p p m})\end{array}$ & $\begin{array}{c}\mathrm{Fe} \\
(\mathbf{p p m})\end{array}$ & $\begin{array}{l}\Sigma \text { LREE } \\
(\mathbf{p p m})\end{array}$ & $\begin{array}{c}\text { ¿HREE } \\
(\mathbf{p p m})\end{array}$ & $\begin{array}{c}\text { Sr } \\
(\mathbf{p p m})\end{array}$ & $\begin{array}{c}\mathbf{T i} \\
(\mathbf{p p m})\end{array}$ & $\begin{array}{l}\text { Temp. } \\
\left({ }^{\circ} \mathbf{C}\right)^{b}\end{array}$ & $\begin{array}{c}\text { Th } \\
(\mathbf{p p m})\end{array}$ & $\underset{(\mathbf{p p m})}{\mathrm{U}}$ & Th/U & $\begin{array}{l}\mathrm{Ce} / \\
\mathrm{Ce}^{* \mathrm{c}}\end{array}$ & $\begin{array}{c}\mathbf{E u} / \\
\mathbf{E u} \mathbf{u}^{* \mathbf{c}}\end{array}$ & $\begin{array}{l}S_{\mathbf{S m}_{\mathrm{N}}{ }^{\mathrm{c}}} \\
/ \mathbf{Y} \mathbf{b}_{\mathbf{N}}{ }^{\mathrm{e}}\end{array}$ & $\begin{array}{l}\delta^{18} \mathbf{O} \\
(\%)\end{array}$ & $\pm 2 \sigma$ & $\begin{array}{c}{ }^{207} \mathrm{~Pb} / 206 \mathrm{~Pb} \\
\text { age (Ma) }\end{array}$ & $\pm 2 \sigma$ & $\begin{array}{c}\text { Pb-Pb } \\
\text { conc. } \\
\text { (\%) }\end{array}$ \\
\hline \multicolumn{20}{|c|}{ (Sub-)euhedral grains } \\
\hline \multicolumn{20}{|c|}{ Grain 1} \\
\hline Core & & & & & & & & & & & & & & & 7.74 & 0.55 & & & \\
\hline \multicolumn{20}{|l|}{ Grain 2} \\
\hline Core & High & 394 & 1381 & 94 & 980 & 94 & 20 & 815 & 1950 & 297 & 6.57 & 3.09 & 0.92 & 0.09 & & & 968 & 22 & 99 \\
\hline \multicolumn{20}{|l|}{ Grain 3} \\
\hline Core & High & 1771 & 3846 & 121 & 1316 & 210 & 239 & 1167 & 2180 & 619 & 3.52 & 3.36 & 0.92 & 0.09 & & & 951 & 19 & 96 \\
\hline Core & High & 1604 & 5262 & 112 & 1202 & 128 & 346 & 1241 & 2088 & 727 & 2.87 & 3.53 & 0.96 & 0.10 & & & 912 & 23 & 86 \\
\hline Core & High & 3377 & 8758 & 112 & 1221 & 312 & 623 & 1373 & 2112 & 1006 & 2.10 & 2.71 & 1.00 & 0.11 & & & 713 & 15 & 58 \\
\hline Core & & & & & & & & & & & & & & & & & & & \\
\hline \multicolumn{20}{|l|}{ Grain 4} \\
\hline Core & & & & & & & & & & & & & & & & & 917 & 11 & 67 \\
\hline Core & High & 3376 & 2890 & 111 & 1147 & 410 & 200 & 1134 & 2137 & 526 & 4.06 & 4.16 & 0.92 & 0.09 & & & 807 & 14 & 84 \\
\hline Core & High & 4260 & 2091 & 144 & 1345 & 648 & 130 & 1061 & 2348 & 369 & 6.36 & 4.27 & 0.93 & 0.10 & & & & & \\
\hline Rim & High & 6890 & 8623 & 147 & 1342 & 879 & 554 & 1344 & 2871 & 817 & 3.52 & 3.31 & 0.96 & 0.11 & & & & & \\
\hline \multicolumn{20}{|l|}{ Grain 5} \\
\hline Core & High & 1580 & 1702 & 78 & 670 & 133 & 196 & 1131 & 921 & 853 & 1.08 & 2.40 & 0.95 & 0.12 & & & 850 & 26 & 101 \\
\hline Rim & High & 187 & 126 & 2.5 & 44 & 5.1 & 9.4 & 740 & 16 & 31 & 0.52 & 2.14 & 0.88 & 0.01 & & & & & \\
\hline Rim & High & 3815 & 3487 & 166 & 1290 & 360 & 503 & 1322 & 2621 & 971 & 2.70 & 2.26 & 0.94 & 0.12 & & & & & \\
\hline Rim & High & 1862 & 973 & 55 & 414 & 357 & 251 & 1177 & 421 & 765 & 0.55 & 1.38 & 0.94 & 0.06 & & & & & \\
\hline \multicolumn{20}{|l|}{ Grain 6} \\
\hline Core & & & & & & & & & & & & & & & 4.81 & 0.56 & & & \\
\hline \multicolumn{20}{|l|}{ Grain 9} \\
\hline Core & & & & & & & & & & & & & & & 2.90 & 0.46 & 965 & 37 & 100 \\
\hline Rim & High & 278 & 139 & 14 & 216 & 18 & 24 & 835 & 246 & 243 & 1.01 & 1.32 & 1.04 & 0.02 & & & & & \\
\hline Rim & High & 1204 & 1758 & 102 & 1062 & 40 & 221 & 1153 & 2415 & 634 & 3.81 & 3.33 & 0.97 & 0.10 & 3.05 & 0.47 & & & \\
\hline \multicolumn{20}{|l|}{ Grain 10} \\
\hline Core & High & 2690 & 3940 & 187 & 1268 & 151 & 78 & 983 & 4274 & 1240 & 3.45 & 2.57 & 0.92 & 0.15 & & & 914 & 12 & 68 \\
\hline Rim & High & 5681 & 6798 & 178 & 1147 & 388 & 105 & 1027 & 2973 & 1102 & 2.70 & 2.10 & 0.91 & 0.14 & & & & & \\
\hline \multicolumn{20}{|l|}{ Grain 11} \\
\hline $\begin{array}{l}\text { Core } \\
\text { Core }\end{array}$ & High & 580 & 990 & 20 & 198 & 69 & 32 & 866 & 469 & 178 & 2.63 & 2.42 & 0.93 & 0.06 & 5.70 & 0.57 & & & \\
\hline Core & High & 1603 & 9440 & 159 & 1139 & 205 & 178 & 1114 & 2519 & 843 & 2.99 & 2.48 & 0.88 & 0.11 & 5.66 & 0.55 & & & \\
\hline Core & High & 312 & 1288 & 12 & 105 & 42 & 25 & 838 & 113 & 75 & 1.52 & 2.23 & 0.93 & 0.06 & & & & & \\
\hline \multicolumn{20}{|l|}{ Grain 12} \\
\hline Core & High & 4244 & 2808 & 230 & 928 & 296 & 651 & 1384 & 1872 & 1031 & 1.82 & 1.28 & 0.94 & 0.13 & & & & & \\
\hline Rim & High & 223 & 74 & 23 & 227 & 19 & 31 & 866 & 263 & 87 & 3.03 & 2.14 & 0.89 & 0.05 & 3.14 & 0.43 & & & \\
\hline \multirow{2}{*}{\multicolumn{20}{|c|}{$\begin{array}{l}\text { Grain } 21 \\
\quad \text { Core }\end{array}$}} \\
\hline \multirow{2}{*}{\multicolumn{20}{|c|}{$\begin{array}{l}\text { Core } \\
\text { Core }\end{array}$}} \\
\hline & & & & & & & & & & & & & & & & & & & \\
\hline \multirow{2}{*}{\multicolumn{20}{|c|}{ Grain 22}} \\
\hline & & & & & & & & & & & & & & & & & & & \\
\hline \multicolumn{20}{|l|}{ Grain 23} \\
\hline Core & High & 2404 & 2471 & 204 & 1304 & 209 & 268 & 1189 & 3220 & 850 & 3.79 & 2.19 & 0.97 & 0.13 & 5.03 & 0.54 & & & \\
\hline & & & & & & & & & & & & & & & & & & & \\
\hline $\begin{array}{l}\text { Core } \\
\text { Rim }\end{array}$ & & & & & & & & & & & & & & & 7.62 & 0.57 & & & \\
\hline Rim & High & 8101 & 2742 & 176 & 1417 & 1062 & 914 & 1473 & 2361 & 1084 & 2.18 & 2.48 & 0.97 & 0.10 & 6.54 & 0.56 & & & \\
\hline
\end{tabular}




\begin{tabular}{|c|c|c|c|c|c|c|c|c|c|c|c|c|c|c|c|c|c|c|c|}
\hline Grain 25 & & & & & & & & & & & & & & & & & & & \\
\hline Core & & & & & & & & & & & & & & & & & 965 & 39 & 93 \\
\hline Grain 26 & & & & & & & & & & & & & & & & & & & \\
\hline Core & & & & & & & & & & & & & & & & & 756 & 113 & 80 \\
\hline Grain 27 & & & & & & & & & & & & & & & & & & & \\
\hline Rim & High & 9249 & 2839 & 199 & 1129 & 1204 & 547 & 1342 & 2626 & 763 & 3.44 & 1.84 & 1.00 & 0.13 & & & & & \\
\hline Rim & & & & & & & & & & & & & & & & & & & \\
\hline Rim & & & & & & & & & & & & & & & & & & & \\
\hline Grain 28 & & & & & & & & & & & & & & & & & & & \\
\hline Rim & & & & & & & & & & & & & & & & & 960 & 28 & 99 \\
\hline Rim & High & 2240 & 401 & 205 & 887 & 247 & 45 & 911 & 2379 & 352 & 6.76 & 1.52 & 0.98 & 0.16 & & & & & \\
\hline $\operatorname{Grain} 29$ & & & & & & & & & & & & & & & & & & & \\
\hline Core & & & & & & & & & & & & & & & & & 855 & 30 & 66 \\
\hline Grain 30 & & & & & & & & & & & & & & & & & & & \\
\hline Core & High & 6705 & 9156 & 272 & 1475 & 320 & 1536 & 1628 & 2514 & 2607 & 0.96 & 1.83 & 0.98 & 0.17 & 6.53 & 0.55 & 946 & 18 & 66 \\
\hline Core & High & 5319 & 6407 & 234 & 1022 & 311 & 1136 & 1534 & 2037 & 1887 & 1.08 & 1.44 & 0.96 & 0.20 & & & & & \\
\hline Rim & High & 2065 & 1993 & 131 & 1098 & 190 & 296 & 1209 & 2146 & 624 & 3.44 & 2.26 & 0.93 & 0.10 & & & & & \\
\hline Rim & High & 3294 & 2384 & 100 & 912 & 428 & 395 & 1268 & 1456 & 572 & 2.55 & 2.33 & 0.91 & 0.10 & 6.97 & 0.56 & & & \\
\hline Grain 31 & & & & & & & & & & & & & & & & & & & \\
\hline Rim & High & 2597 & 2274 & 162 & 515 & 366 & 130 & 1062 & 2065 & 659 & 3.13 & 1.39 & 1.00 & 0.16 & 5.48 & 0.54 & & & \\
\hline Rim & & & & & & & & & & & & & & & & & & & \\
\hline Rim & & & & & & & & & & & & & & & & & & & \\
\hline Grain 32 & & & & & & & & & & & & & & & & & & & \\
\hline Core & & & & & & & & & & & & & & & 5.19 & 0.55 & 962 & 32 & 100 \\
\hline Grain 33 & & & & & & & & & & & & & & & & & & & \\
\hline Core & High & 4181 & 3720 & 138 & 793 & 555 & 459 & 1301 & 2077 & 698 & 2.98 & 5.81 & 0.29 & 0.10 & 4.28 & 0.58 & 802 & 13 & 44 \\
\hline Grain 34 & & & & & & & & & & & & & & & & & & & \\
\hline Rim & High & 17571 & 10434 & 204 & 1511 & 2460 & 1088 & 1522 & 3707 & 1256 & 2.95 & 2.35 & 1.01 & 0.14 & 7.81 & 0.54 & & & \\
\hline Rim & & & & & & & & & & & & & & & & & & & \\
\hline Core & High & 7524 & 3721 & 193 & 1351 & 1086 & 244 & 1171 & 2116 & 385 & 5.49 & 1.96 & 0.96 & 0.11 & 4.64 & 0.56 & & & \\
\hline Core & & & & & & & & & & & & & & & & & & & \\
\hline Grain 35 & & & & & & & & & & & & & & & & & & & \\
\hline Core & & & & & & & & & & & & & & & & & 963 & 38 & 93 \\
\hline Rim & High & 2595 & 5005 & 143 & 651 & 181 & 390 & 1266 & 2620 & 693 & 3.78 & 1.82 & 0.99 & 0.19 & & & & & \\
\hline Rim & & & & & & & & & & & & & & & & & & & \\
\hline Grain 36 & & & & & & & & & & & & & & & & & & & \\
\hline Rim & & & & & & & & & & & & & & & & & & & \\
\hline Core & High & 1931 & 1466 & 118 & 973 & 170 & 138 & 1071 & 2377 & 938 & 2.53 & 14.04 & 0.29 & 0.10 & 5.81 & 0.59 & 941 & 17 & 94 \\
\hline Grain 37 & & & & & & & & & & & & & & & & & & & \\
\hline Core & High & 4625 & 3765 & 301 & 1691 & 609 & 613 & 1369 & 5524 & 1415 & 3.90 & 1.79 & 0.97 & 0.15 & & & 952 & 19 & 101 \\
\hline Grain 38 & & & & & & & & & & & & & & & & & & & \\
\hline Core & & & & & & & & & & & & & & & 7.34 & 0.53 & & & \\
\hline Core & & & & & & & & & & & & & & & 6.13 & 0.54 & & & \\
\hline Intermed & grains & & & & & & & & & & & & & & & & & & \\
\hline Grain 15 & & & & & & & & & & & & & & & & & & & \\
\hline Core & High & 381 & 116 & 50 & 881 & 46 & 8.9 & 736 & 701 & 484 & 1.45 & 4.05 & 0.94 & 0.06 & & & 961 & 23 & 100 \\
\hline Core & High & 631 & 274 & 40 & 672 & 49 & 42 & 901 & 690 & 337 & 2.05 & 4.90 & 0.92 & 0.06 & & & & & \\
\hline Core & High & 4223 & 2141 & 115 & 1082 & 284 & 331 & 1231 & 2187 & 636 & 3.44 & 3.09 & 0.94 & 0.09 & & & & & \\
\hline Rim & High & 236 & 127 & 22 & 365 & 23 & 9.0 & 736 & 257 & 221 & 1.16 & 3.59 & 0.95 & 0.05 & & & & & \\
\hline Rim & Low & 124 & 39 & 5.1 & 43 & 11 & 6.9 & 712 & 32 & 34 & 0.93 & 2.18 & 1.28 & 0.05 & & & & & \\
\hline Rim & Low & 167 & 78 & 5.4 & 125 & 7.7 & 13 & 770 & 53 & 56 & 0.94 & 3.56 & 1.13 & 0.02 & & & & & \\
\hline $\operatorname{Grain} 19$ & & & & & & & & & & & & & & & & & & & \\
\hline Core & & & & & & & & & & & & & & & & & 962 & 65 & 100 \\
\hline Core & High & 2473 & 1086 & 203 & 392 & 301 & 234 & 1164 & 696 & 289 & 2.41 & 1.28 & 1.08 & 0.22 & & & & & \\
\hline Rim & Low & 66 & 20 & 1.3 & 35 & 1.1 & 2.3 & 626 & 8.2 & 17 & 0.47 & 3.09 & 0.93 & 0.02 & & & & & \\
\hline Rim & Low & 106 & 23 & 3.9 & 36 & 5.8 & 7.5 & 719 & 17 & 24 & 0.71 & 1.07 & 1.19 & 0.04 & & & 970 & 91 & 98 \\
\hline
\end{tabular}

http://www.petrology.oupjournals.org/ 
Grin 7

\begin{tabular}{|c|c|c|c|c|c|c|c|c|c|c|c|c|c|c|c|c|c|c|c|}
\hline Core & Low & 170 & 55 & 1.5 & 39 & 0.9 & 2.6 & 632 & 12 & 29 & 0.40 & 2.12 & 0.97 & 0.01 & 5.08 & 0.53 & 923 & 40 & 102 \\
\hline Core & High & 187 & 90 & 2.0 & 27 & 2.8 & 5.5 & 693 & 12 & 47 & 0.25 & 3.31 & 0.95 & 0.02 & & & 946 & 72 & 100 \\
\hline Core & Low & 174 & 56 & 1.0 & 22 & 1.5 & 2.6 & 634 & 7.3 & 28 & 0.26 & 3.39 & 1.01 & 0.02 & & & & & \\
\hline Rim & High & 193 & 62 & 0.6 & 25 & 0.5 & 1.6 & 600 & 2.8 & 23 & 0.12 & 3.51 & 0.54 & 0.02 & & & & & \\
\hline Rim & High & 178 & 388 & 3.8 & 27 & 13 & 8.0 & 725 & 10 & 21 & 0.49 & 1.31 & 0.98 & 0.04 & 5.75 & 0.57 & & & \\
\hline \multicolumn{20}{|l|}{ Grain 8} \\
\hline & & & & & & & & & & & & & & & 1.29 & 0.43 & & & \\
\hline \multicolumn{20}{|l|}{ Grain 13} \\
\hline Core & Low & 67 & 21 & 0.7 & 13 & 0.2 & 2.0 & 615 & 4.5 & 15 & 0.31 & 19.61 & 0.68 & 0.02 & 2.72 & 0.44 & 931 & 53 & 97 \\
\hline Core & Low & 69 & 22 & 0.5 & 17 & 0.1 & 2.4 & 626 & 3.3 & 15 & 0.22 & 9.39 & 0.81 & 0.01 & 2.67 & 0.41 & 942 & 32 & 99 \\
\hline \multicolumn{20}{|l|}{ Grain 14} \\
\hline Core & Low & 76 & 21 & 3.7 & 160 & 1.8 & 2.1 & 617 & 24 & 41 & 0.58 & 3.86 & 0.79 & 0.01 & & & 967 & 30 & 100 \\
\hline Core & Low & 68 & 21 & 1.3 & 49 & 0.8 & 1.8 & 607 & 6.9 & 16 & 0.42 & 3.45 & 0.81 & 0.01 & & & & & \\
\hline Core & & & & & & & & & & & & & & & & & 961 & 37 & 99 \\
\hline Core & Low & 65 & 20 & 0.9 & 22 & 0.6 & 1.7 & 604 & 4.5 & 14 & 0.33 & 3.68 & 0.81 & 0.01 & & & 983 & 33 & 97 \\
\hline Core & Low & 111 & 19 & 3.2 & 52 & 10 & 1.6 & 600 & 10 & 21 & 0.50 & 1.41 & 0.85 & 0.02 & & & 983 & 33 & 97 \\
\hline Core & & & & & & & & & & & & & & & & & & & \\
\hline \multicolumn{20}{|l|}{ Grain 16} \\
\hline Core & Low & 132 & 25 & 8.5 & 42 & 10 & 5.1 & 687 & 30 & 26 & 1.13 & 1.53 & 1.05 & 0.06 & & & 1037 & 63 & 92 \\
\hline Rim & Low & 74 & 23 & 4.4 & 122 & 3.5 & 2.4 & 626 & 58 & 54 & 1.08 & 3.95 & 0.83 & 0.02 & & & & & \\
\hline \multicolumn{20}{|l|}{ Rim } \\
\hline Rim & Low & 63 & 20 & 4.1 & 159 & 0.8 & 2.5 & 631 & 35 & 48 & 0.73 & 6.27 & 0.85 & 0.02 & & & & & \\
\hline Core & Low & 81 & 20 & 4.3 & 45 & 5.8 & 2.6 & 634 & 26 & 26 & 1.00 & 1.94 & 0.93 & 0.04 & & & 1018 & 40 & 86 \\
\hline Rim & Low & 109 & 20 & 5.4 & 58 & 7.0 & 2.3 & 624 & 15 & 17 & 0.84 & 1.57 & 0.98 & 0.03 & & & & & \\
\hline \multicolumn{20}{|l|}{ Grain 17} \\
\hline Core & Low & 65 & 20 & 0.9 & 29 & 0.8 & 2.1 & 618 & 6.5 & 15 & 0.42 & 6.32 & 0.92 & 0.02 & & & & & \\
\hline Core & Low & 213 & 23 & 1.6 & 32 & 1.3 & 3.3 & 652 & 6.0 & 20 & 0.30 & 6.30 & 1.04 & 0.01 & & & & & \\
\hline Core & Low & 59 & 18 & 1.6 & 30 & 1.4 & 2.1 & 616 & 5.0 & 16 & 0.30 & 2.80 & 0.89 & 0.02 & 2.47 & 0.44 & 910 & 62 & 97 \\
\hline Core & Low & 97 & 39 & 2.6 & 32 & 7.8 & 11 & 752 & 10 & 32 & 0.31 & 2.29 & 0.92 & 0.04 & & & & & \\
\hline Core & & & & & & & & & & & & & & & 3.96 & 0.41 & 1026 & 26 & 93 \\
\hline Rim & Low & 193 & 42 & 4.2 & 40 & 17 & 14 & 781 & 18 & 22 & 0.83 & 1.70 & 1.00 & 0.04 & 2.40 & 0.46 & & & \\
\hline Rim & Low & 62 & 19 & 0.9 & 31 & 0.7 & 2.1 & 619 & 3.7 & 15 & 0.24 & 5.66 & 0.93 & 0.01 & & & 1026 & 26 & 93 \\
\hline \multicolumn{20}{|l|}{ Grain 18} \\
\hline Core & Low & 64 & 20 & 5.1 & 174 & 4.2 & 3.0 & 644 & 76 & 110 & 0.69 & 4.92 & 0.79 & 0.01 & 2.22 & 0.45 & 951 & 37 & 100 \\
\hline \multirow{2}{*}{\multicolumn{20}{|c|}{$\begin{array}{l}\text { Core } \\
\text { Core }\end{array}$}} \\
\hline & & & & & & & & & & & & & & & & & & & \\
\hline Core & & & & & & & & & & & & & & & 2.31 & 0.42 & 962 & 47 & 99 \\
\hline Core & Low & 62 & 20 & 5.4 & 267 & 0.5 & 1.9 & 611 & 40 & 73 & 0.55 & 12.90 & 0.82 & 0.02 & & & 956 & 23 & 100 \\
\hline Core & High & 118 & 63 & 16 & 456 & 8.3 & 11 & 755 & 183 & 203 & 0.90 & 4.25 & 0.92 & 0.03 & 3.10 & 0.45 & 918 & 10 & 96 \\
\hline \multicolumn{20}{|l|}{ Core } \\
\hline Core & & & & & & & & & & & & & & & & & 959 & 44 & 99 \\
\hline Core & & & & & & & & & & & & & & & & & 970 & 68 & 94 \\
\hline Rim & Low & 123 & 22 & 1.7 & 33 & 25 & 3.4 & 653 & 7.5 & 17 & 0.43 & 2.13 & 0.89 & 0.02 & 1.45 & 0.46 & & & \\
\hline Rim & Low & 78 & 22 & 1.1 & 66 & 0.2 & 1.3 & 584 & 14 & 33 & 0.43 & 25.83 & 0.80 & 0.01 & 2.22 & 0.45 & 951 & 37 & 100 \\
\hline \multicolumn{20}{|l|}{ Grain 20} \\
\hline Core & Low & 65 & 20 & 1.4 & 38 & 1.8 & 2.1 & 616 & 5.0 & 16 & 0.32 & 2.86 & 0.82 & 0.01 & 3.00 & 0.42 & & & \\
\hline \multicolumn{20}{|l|}{ Core } \\
\hline Core & Low & 63 & 20 & 1.6 & 55 & 1.4 & 2.8 & 640 & 7.1 & 21 & 0.34 & 2.92 & 0.86 & 0.01 & & & & & \\
\hline Core & Low & 72 & 19 & 3.1 & 39 & 4.0 & 6.5 & 707 & 15 & 24 & 0.64 & 1.83 & 0.97 & 0.03 & & & & & \\
\hline Rim & & & & & & & & & & & & & & & 1.99 & 0.44 & & & \\
\hline
\end{tabular}

Zonation ordered from cores towards rims in each grain.

Calculations based on the $\mathrm{Ti}$-in-zircon thermometer of Ferry and Watson (2007) using in all cases $\mathrm{a}\left(\mathrm{SiO}_{2}\right)=1$ and a( $\left.\mathrm{TiO}_{2}\right)=1$. The correlation between $\mathrm{Ti}$ and $\mathrm{Ca}+\mathrm{Fe}$ suggest that the $\mathrm{Ti}$ content of (sub-)euhedral zircon grains was not only controlled by the zircon lattice (and associated thermal conditions), but very likely also by interstitial domains, causing an overestimation and therefore unrealistic zircon crystallization temperatures. See text for details.

${ }^{c}$ Chondrite normalization after McDonough and Sun (1995). 
Table 6. U-Pb dating of apatite from carbonatite facies (sample 12-PA-007-A6) of the Crevier alkaline intrusion from the central Grenville Province.

\begin{tabular}{|c|c|c|c|c|c|c|}
\hline \multirow[t]{2}{*}{ Analysis no. } & \multicolumn{2}{|c|}{ Concentrations } & \multicolumn{2}{|c|}{ Isotopic ratios } & \multirow[b]{2}{*}{${ }^{207} \mathrm{~Pb} /{ }^{206} \mathrm{~Pb}$} & \multirow[b]{2}{*}{$2 \sigma$} \\
\hline & $\mathrm{Pb}(\mathrm{ppm})$ & $\mathrm{U}(\mathbf{p p m})$ & ${ }^{238} \mathrm{U} /{ }^{206} \mathrm{~Pb}$ & $2 \sigma$ & & \\
\hline Ap-1 & 3.8 & 4.2 & 3.46 & 0.14 & 0.50 & 0.01 \\
\hline Ap-2 & 3.7 & 4.4 & 3.70 & 0.16 & 0.46 & 0.01 \\
\hline Ap-3 & 18 & 1.1 & 0.36 & 0.02 & 0.92 & 0.02 \\
\hline $\mathrm{Ap}-4$ & 7.8 & 0.9 & 0.53 & 0.03 & 0.87 & 0.03 \\
\hline Ap-5 & 3.3 & 4.6 & 4.21 & 0.18 & 0.45 & 0.01 \\
\hline Ap- 6 & 8.9 & 1.1 & 0.59 & 0.04 & 0.88 & 0.04 \\
\hline Ap-7 & 3.5 & 4.1 & 3.65 & 0.16 & 0.47 & 0.01 \\
\hline Ap-8 & 3.4 & 3.5 & 3.38 & 0.15 & 0.49 & 0.01 \\
\hline Ap-9 & 3.7 & 3.6 & 3.32 & 0.14 & 0.52 & 0.01 \\
\hline Ap-10 & 3.5 & 3.5 & 3.21 & 0.14 & 0.50 & 0.01 \\
\hline Ap-11 & 3.5 & 3.6 & 3.37 & 0.16 & 0.48 & 0.01 \\
\hline Ap-12 & 4.0 & 4.1 & 3.25 & 0.15 & 0.51 & 0.01 \\
\hline Ap-13 & 3.5 & 4.1 & 3.57 & 0.15 & 0.45 & 0.01 \\
\hline Ap-14 & 4.3 & 4.4 & 3.32 & 0.15 & 0.48 & 0.02 \\
\hline Ap-15 & 4.7 & 4.3 & 3.12 & 0.16 & 0.51 & 0.02 \\
\hline Ap-16 & 4.2 & 4.1 & 3.36 & 0.11 & 0.50 & 0.01 \\
\hline Ap-17 & 4.1 & 4.5 & 3.22 & 0.21 & 0.51 & 0.01 \\
\hline Ap-18 & 4.2 & 4.7 & 3.45 & 0.11 & 0.50 & 0.01 \\
\hline Ap-19 & 3.1 & 2.9 & 3.02 & 0.15 & 0.49 & 0.03 \\
\hline Ap-20 & 2.9 & 2.7 & 3.05 & 0.17 & 0.49 & 0.02 \\
\hline Ap-21 & 13 & 0.6 & 0.34 & 0.01 & 0.90 & 0.01 \\
\hline Ap-22 & 11 & 0.8 & 0.45 & 0.02 & 0.87 & 0.02 \\
\hline Ap-23 & 3.3 & 3.8 & 3.35 & 0.13 & 0.45 & 0.01 \\
\hline Ap-24 & 3.6 & 4.1 & 3.33 & 0.17 & 0.50 & 0.01 \\
\hline Ap- 25 & 8.5 & 0.7 & 0.49 & 0.02 & 0.89 & 0.02 \\
\hline Ap-26 & 3.6 & 5.0 & 3.92 & 0.18 & 0.46 & 0.02 \\
\hline
\end{tabular}


Table 7: $\delta^{18} \mathrm{O}_{\mathrm{V}-\mathrm{SMOW}}$ and $\delta^{13} \mathrm{C}_{\mathrm{V}-\mathrm{PDB}}$ composition of calcite from carbonatite facies (samples 12PA-019-A, 12-PA-007-A6 and 12-PA-009-A5) of the Crevier alkaline intrusion from the central Grenville Province.

\begin{tabular}{llcccc}
\hline Sample & Facies & $\boldsymbol{\delta}^{\mathbf{1 0}} \mathbf{O}(\% \mathbf{~ V - S M O W})$ & $2 \boldsymbol{\sigma}$ & $\boldsymbol{\delta}^{\mathbf{1 3}} \mathbf{C}(\% \circ \mathbf{P D B})$ & $\mathbf{2 \sigma}$ \\
\hline 12-PA-019-A & Carbonatite & +7.05 & 0.20 & -6.42 & 0.10 \\
12-PA-007-A6 & Carbonatite & +6.73 & 0.20 & -6.78 & 0.10 \\
12-PA-009-A5 & Carbonatite & +7.35 & 0.20 & -6.14 & 0.10 \\
\hline
\end{tabular}

